Prepared in cooperation with the Bureau of Reclamation

\title{
Macrophyte and pH Buffering Updates to the Klamath River Water-Quality Model Upstream of Keno Dam, Oregon
}

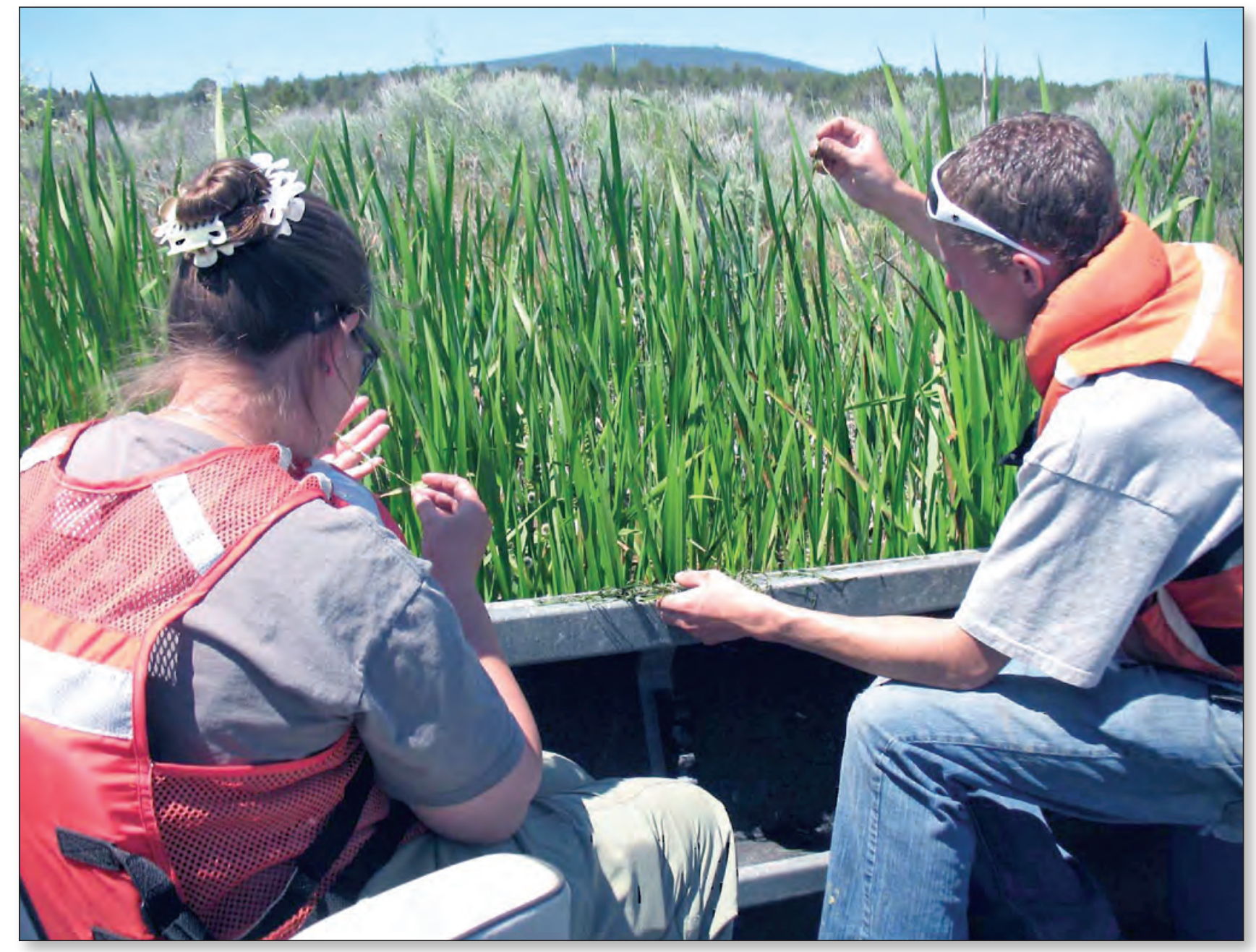

Scientific Investigations Report 2013-5016 
Front cover: Photograph showing Jessica Asbill-Case and Garrett Steensland, Bureau of Reclamation, examining macrophyte samples from the Link River to Keno Dam reach of the Klamath River, Oregon. (Photograph by Bureau of Reclamation field crew, 2011.)

Back cover (top left): Photograph of a Curlyleaf pondweed (Potamogeton crispus) sample from the Link River to Keno Dam reach of the Klamath River, Oregon. (Photograph by Bureau of Reclamation field crew, 2011.)

Back cover (top right): Photograph of a Common waterweed (Elodea canadensis) sample from the Link River to Keno Dam reach of the Klamath River, Oregon.

(Photograph by Bureau of Reclamation field crew, 2011.)

Back cover (bottom left): Photograph of a Small pondweed (Potamogeton pusillus) sample from the Link River to Keno Dam reach of the Klamath River, Oregon. (Photograph by Bureau of Reclamation field crew, 2011.)

Back cover (bottom right): Photograph of a Coontail (Ceratophyllum demersum) sample from the Link River to Keno Dam reach of the Klamath River, Oregon.

(Photograph by Bureau of Reclamation field crew, 2011.) 


\section{Macrophyte and pH Buffering Updates to the Klamath River Water-Quality Model Upstream of Keno Dam, Oregon}

By Annett B. Sullivan and Stewart A. Rounds, U.S. Geological Survey; Jessica R. Asbill-Case, Bureau of Reclamation; Michael L. Deas, Watercourse Engineering, Inc.

Prepared in cooperation with the Bureau of Reclamation

Scientific Investigations Report 2013-5016 


\section{U.S. Department of the Interior \\ KEN SALAZAR, Secretary}

\section{U.S. Geological Survey \\ Suzette M. Kimball, Acting Director}

U.S. Geological Survey, Reston, Virginia: 2013

For more information on the USGS — the Federal source for science about the Earth, its natural and living resources, natural hazards, and the environment, visit http://www.usgs.gov or call 1-888-ASK-USGS.

For an overview of USGS information products, including maps, imagery, and publications, visit http://www.usgs.gov/pubprod

To order this and other USGS information products, visit http://store.usgs.gov

Any use of trade, firm, or product names is for descriptive purposes only and does not imply endorsement by the U.S. Government.

Although this information product, for the most part, is in the public domain, it also may contain copyrighted materials as noted in the text. Permission to reproduce copyrighted items must be secured from the copyright owner.

Suggested citation:

Sullivan, A.B., Rounds, S.A., Asbill-Case, J.R., and Deas, M.L., 2013, Macrophyte and pH buffering updates to the Klamath River water-quality model upstream of Keno Dam, Oregon: U.S. Geological Survey Scientific Investigations Report 2013-5016, 52 p. 


\section{Contents}

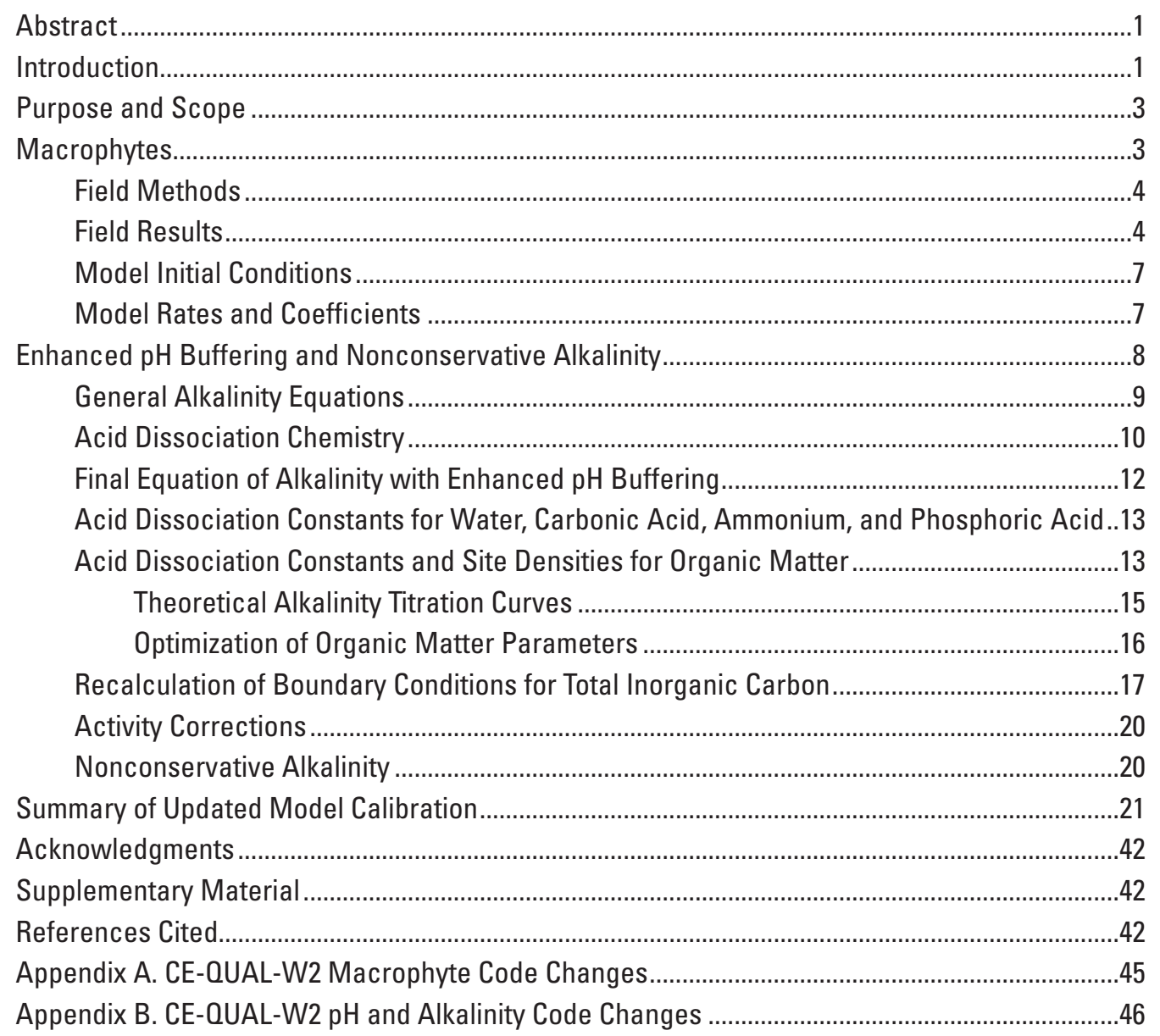




\section{Figures}

1. Map showing location of the study reach and sampling locations in Link River to Keno Dam reach of the Klamath River, Oregon. WWTP, wastewater treatment plant

2. Graph showing mid-channel Secchi depth for the June, August, and October 2011 macrophyte sampling events in the Link River to Keno Dam reach of the Klamath River, Oregon

3. Graphs showing estimated dry weight biomass for the most commonly identified macrophytes at June, August, and October 2011 sampling events in the Link River to Keno Dam reach of the Klamath River, Oregon

4. Graph showing a summation of site densities for two hypothetical Gaussian distributions of $\mathrm{pK}_{\mathrm{a}}$ values....

5. Graphs showing example titration curves of four theoretical titration curves and measured data from the Link River to Keno Dam reach of the Klamath River, Oregon

6. Graphs showing modeled macrophyte biomass along the Link River to Keno Dam reach of the Klamath River, Oregon, on two selected dates

7. Graphs showing modeled daily average dissolved-oxygen production sources and consumption sinks in the Link River to Keno Dam reach of the Klamath River, Oregon, in 2008

8. Graphs showing modeled and measured $\mathrm{pH}$ at the Klamath River, Oregon, Railroad Bridge site in summer and fall 2007, without and with the new enhanced CE-OUAL-W2 pH buffering

9. Graphs showing modeled and measured $\mathrm{pH}$ at the Klamath River, Oregon, Keno site in summer and fall 2007, without macrophytes and with macrophytes ...

10. Graphs showing measured and modeled hourly $\mathrm{pH}$ during calendar years 2006, 2007, 2008, and 2009 for sites in the Link River to Keno Dam reach of the Klamath River, Oregon

11. Graphs showing measured and modeled hourly dissolved-oxygen concentrations during calendar years2006, 2007, 2008, and 2009 for sites in the Link River to Keno Dam reach of the Klamath River, Oregon

12. Graphs showing measured and modeled algae, nutrients, organic matter, and bottom sediment during calendar years 2006, 2007, 2008, and 2009 for sites in the Link River to Keno Dam reach of the Klamath River, Oregon 


\section{Tables}

1. Submergent species identified at June 27-July 7, August 15-19, and October 11-13, 2011 sampling events in the Link River to Keno Dam reach of the upper Klamath River, Oregon

2. Macrophyte parameters in the updated water-quality model for the Link River to Keno Dam reach of the Klamath River, Oregon

3. Acid dissociation constants for water, carbonic acid, ammonium, and phosphoric acid used in the model of the Link River to Keno Dam reach of the Klamath River, Oregon

4. Dissolved organic-matter acid dissociation constants and site densities for the Link River to Keno Dam reach of the Klamath River, Oregon, resulting from two best-fit optimizations of 24 measured alkalinity titration curves.

5. Parameter values changed as a result of calibration updates to the water-quality model for the Link River to Keno Dam reach of the Klamath River, Oregon

6. Enhanced $\mathrm{pH}$ buffering input parameters in the water-quality model for the Link River to Keno Dam reach of the Klamath River, Oregon ....

7. Goodness-of-fit statistics averaged over all calibration sites for the updated model of the Link River to Keno Dam reach of the Klamath River, Oregon 


\title{
Conversion Factors, Datums, and Abbreviations
}

\author{
Conversion Factors
}

Inch/Pound to SI

\begin{tabular}{lll}
\hline \multicolumn{1}{c}{ Multiply } & \multicolumn{1}{c}{ By } & \multicolumn{1}{c}{ To obtain } \\
\hline foot (ft) & 0.3048 & meter (m) \\
mile (mi) & 1.609 & kilometer (km) \\
cubic inches (in. $\left.{ }^{3}\right)$ & 0.01639 & liter (L) \\
\hline
\end{tabular}

SI to Inch/Pound

\begin{tabular}{lcl}
\hline \multicolumn{1}{c}{ Multiply } & By & \multicolumn{1}{c}{ To obtain } \\
\hline micron $(\mu \mathrm{m})$ & 0.00003937 & inch (in) \\
millimeter $(\mathrm{mm})$ & 0.03937 & inch (in) \\
meter $(\mathrm{m})$ & 3.281 & foot (ft) \\
square meter $\left(\mathrm{m}^{2}\right)$ & $1,550.0$ & square inch (in $\left.{ }^{2}\right)$ \\
gram $(\mathrm{g})$ & 0.03527 & ounce, avoirdupois (oz) \\
kilogram $(\mathrm{kg})$ & 2.205 & pound avoirdupois (lb) \\
liter $(\mathrm{L})$ & 33.82 & ounce, fluid (fl oz) \\
liter $(\mathrm{L})$ & 0.2642 & gallon (gal) \\
milliliter $(\mathrm{mL})$ & 0.03382 & ounce, fluid (fl oz) \\
liter $(\mathrm{L})$ & 61.02 & cubic inch (in $\left.{ }^{3}\right)$ \\
cubic meter $\left(\mathrm{m}^{3}\right)$ & 35.31 & cubic foot (ft $\left.{ }^{3}\right)$ \\
cubic meter $\left(\mathrm{m}^{3}\right)$ & 264.2 & gallon (gal) \\
milligram per liter $(\mathrm{mg} / \mathrm{L})$ & 1.0 & parts per million (ppm) \\
Watt $(\mathrm{W})$ & 3.41 & British thermal unit per hour (BTU/h) \\
\hline
\end{tabular}

Temperature in degrees Celsius $\left({ }^{\circ} \mathrm{C}\right)$ may be converted to degrees Fahrenheit $\left({ }^{\circ} \mathrm{F}\right)$ as follows:

${ }^{\circ} \mathrm{F}=\left(1.8 \mathrm{x}^{\circ} \mathrm{C}\right)+32$.

Concentrations of chemical constituents in water are given either in milligrams per liter $(\mathrm{mg} / \mathrm{L})$, which is approximately equivalent to parts per million (ppm), or micrograms per liter ( $\mu \mathrm{g} / \mathrm{L})$, which is approximately equivalent to parts per billion (ppb).

Datums

Elevation refers to distance above the vertical datum. A local vertical datum (UKLVD) is used, established by the Bureau of Reclamation. For the purpose of this report, the conversion is UKLVD $-1.78 \mathrm{ft}=$ NGVD29.

Horizontal coordinate information is referenced to the North American Datum of 1983 (NAD 83). 
Abbreviations

$\begin{array}{ll}\mathrm{K}_{\mathrm{a}} & \text { acid dissociation constant } \\ < & \text { less than } \\ \leq & \text { less than or equal to } \\ \mathrm{DOC} & \text { dissolved organic carbon } \\ > & \text { greater than } \\ \geq & \text { greater than or equal to } \\ \mathrm{pK}_{\mathrm{a}} & \text { acid dissociation constant } \\ \text { MAE } & \text { mean absolute error } \\ \text { POC } & \text { particulate organic carbon } \\ \text { POM } & \text { particulate organic matter } \\ \text { SRP } & \text { soluble reactive phosphorus } \\ \text { TMDL } & \text { total maximum daily load } \\ \text { USGS } & \text { U.S. Geological Survey }\end{array}$


This page intentionally left blank. 


\title{
Macrophyte and pH Buffering Updates to the Klamath River Water-Quality Model Upstream of Keno Dam, Oregon
}

\author{
By Annett B. Sullivan', Stewart A. Rounds', Jessica R. Asbill-Case'2, and Michael L. Deas³
}

\section{Abstract}

A hydrodynamic, water temperature, and water-quality model of the Link River to Keno Dam reach of the upper Klamath River was updated to account for macrophytes and enhanced $\mathrm{pH}$ buffering from dissolved organic matter, ammonia, and orthophosphorus. Macrophytes had been observed in this reach by field personnel, so macrophyte field data were collected in summer and fall (June-October) 2011 to provide a dataset to guide the inclusion of macrophytes in the model. Three types of macrophytes were most common: pondweed (Potamogeton species), coontail (Ceratophyllum demersum), and common waterweed (Elodea canadensis). Pondweed was found throughout the Link River to Keno Dam reach in early summer with densities declining by mid-summer and fall. Coontail and common waterweed were more common in the lower reach near Keno Dam and were at highest density in summer. All species were most dense in shallow water (less than 2 meters deep) near shore. The highest estimated dry weight biomass for any sample during the study was 202 grams per square meter for coontail in August. Guided by field results, three macrophyte groups were incorporated into the CE-QUAL-W2 model for calendar years 2006-09. The CE-QUAL-W2 model code was adjusted to allow the user to initialize macrophyte populations spatially across the model grid.

The default CE-QUAL-W2 model includes $\mathrm{pH}$ buffering by carbonates, but does not include $\mathrm{pH}$ buffering by organic matter, ammonia, or orthophosphorus. These three constituents, especially dissolved organic matter, are present in the upper Klamath River at concentrations that provide substantial $\mathrm{pH}$ buffering capacity. In this study, CE-QUAL-W2 was updated to include this enhanced buffering capacity in the simulation of $\mathrm{pH}$. Acid dissociation constants for ammonium and phosphoric acid were taken from the literature. For dissolved organic matter, the number of organic acid groups and each group's acid dissociation constant $\left(\mathrm{K}_{\mathrm{a}}\right)$ and site density (moles of sites per mole of carbon) were derived by fitting a theoretical buffering response to measured upper Klamath River alkalinity titration curves. The organic matter buffering in the Klamath River was modeled with two monoprotic organic acids: carboxylic acids with a mean $\mathrm{pK}_{\mathrm{a}}$ of 5.584 and site density of 0.1925 , and phenolic organic acids with a mean $\mathrm{pK}_{\mathrm{a}}$ of 9.594 and site density of 0.6466 . Total inorganic carbon concentrations in the model boundary inputs were recalculated based on the new buffering equations. CE-QUAL-W2 was also adjusted to allow the simulation of nonconservative alkalinity caused by nitrification, denitrification, photosynthesis, and respiration. The Klamath River model was recalibrated after the macrophyte and $\mathrm{pH}$ buffering updates producing improved predictions for $\mathrm{pH}$, dissolved oxygen, and particulate carbon.

\section{Introduction}

The Klamath River flows about $255 \mathrm{mi}(410 \mathrm{~km})$ from the outlet of Upper Klamath Lake to the Pacific Ocean through southern Oregon and northern California. The first 1-mile reach downstream of Upper Klamath Lake (from Link River Dam to near sampling site 11507501; fig. 1) is named Link River; the Klamath River proper begins at the mouth of Link River. Stage in the next 20 miles is controlled by Keno Dam (fig. 1). Water quality in the Link River to Keno Dam reach has been designated as "water quality limited" for exceeding ammonia toxicity and dissolved oxygen criteria year-round, and $\mathrm{pH}$ and chlorophyll $a$ criteria in summer (Oregon Department of Environmental Quality, 2007). A Total Maximum Daily Load (TMDL) plan for this reach of the Klamath River (Oregon Department of Environmental Quality, 2010) was approved by the U.S. Environmental Protection Agency in May 2012. Water temperature allocations have also been established for point and nonpoint sources in this reach, due to the water temperature TMDL below Keno Dam.

\footnotetext{
${ }^{1}$ U.S. Geological Survey

${ }^{2}$ Bureau of Reclamation

${ }^{3}$ Watercourse Engineering, Inc.
} 


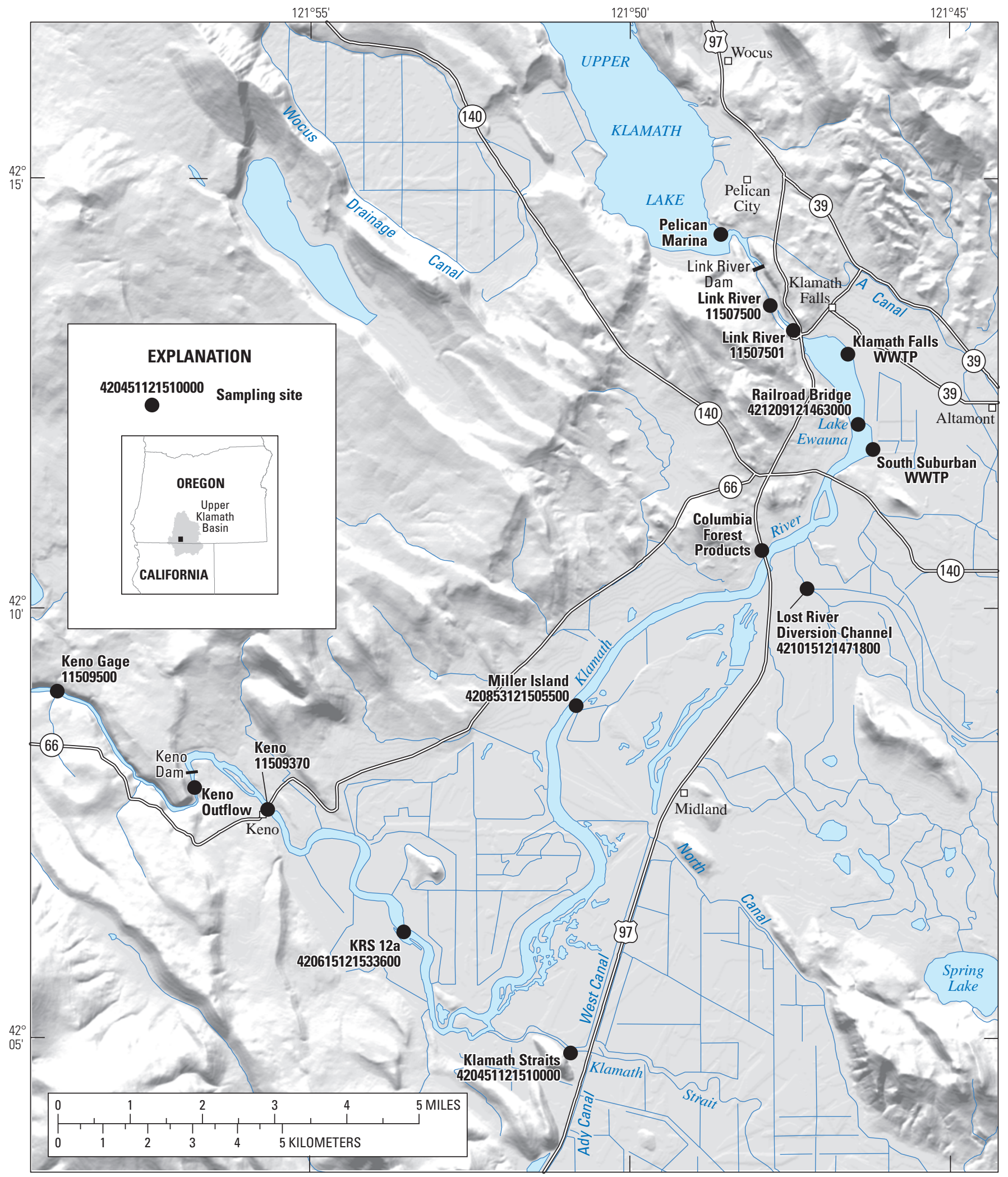

Figure 1. Location of the study reach and sampling locations in Link River to Keno Dam reach of the Klamath River, Oregon. WWTP, wastewater treatment plant. 
Water quality in this reach is affected by hydrology, atmospheric conditions, tributaries and upstream inputs, withdrawals, instream biogeochemistry, and biota. Mechanistic computer models such as CE-QUAL-W2 (Cole and Wells, 2008) include many of these processes that affect water quality, and the models are regularly used to provide insights on the relative importance, rates, and other characteristics of the processes. Models can also be used to make predictions about the effects of system changes on water quality. The Klamath River TMDL was based in part on a CE-QUAL-W2 model for the years 2000 and 2002 (Tetra Tech, Inc., 2009; Rounds and Sullivan, 2009; Rounds and Sullivan, 2010).

The U.S. Geological Survey (USGS), Bureau of Reclamation (Reclamation), and Watercourse Engineering, Inc. (Watercourse) initiated a project in 2006 that led to an improved understanding of water-quality processes in the Link River to Keno Dam reach of the Klamath River. Two years of field data were collected in 2007 and 2008, with additional experimental work to investigate the characteristics of flow, suspended matter settling, and dissolved oxygen and organic matter dynamics (Sullivan and others, 2008, 2009, 2010; Poulson and Sullivan, 2010; Deas and Vaughn, 2011). Continuous water-quality monitoring at 12 sites by Reclamation in 2006-09 contributed valuable time-dense data for model calibration and for helping to understand water-quality dynamics in the system. A CE-QUAL-W2 model was constructed for years 2006-09 based on these extensive datasets and an improved understanding of instream processes (Sullivan and others, 2011). This USGS-Watercourse-Reclamation model (henceforth simply called the USGS model) was originally configured to simulate stage, flow, water velocity, ice cover, water temperature, specific conductance, inorganic suspended sediment, three algal groups, total nitrogen, total phosphorus, particulate nitrogen, particulate carbon, sediment organic matter, dissolved oxygen, dissolved organic carbon, and dissolved nitrate, ammonia, and orthophosphorus. In CE-QUAL-W2, orthophosphorus is used to model bioavailable phosphorus, which is often measured as soluble reactive phosphorus (SRP), orthophosphate, or dissolved phosphorus.

CE-QUAL-W2 is a two-dimensional model used to simulate variability from upstream to downstream and from the river surface to the channel bottom. The third dimension, from bank to bank, is considered to be well mixed in this model. The USGS upper Klamath River model grid consists of 102 segments that connect together in the direction of flow; segments average 1,009 $\mathrm{ft}(308 \mathrm{~m})$ in length. Each segment represents a cross-sectional shape of the river channel, with stacked layers of varying width from the river surface to the channel bottom. Vertical layers are $2 \mathrm{ft}(0.61 \mathrm{~m})$ in height. The model runs on a variable time step that can be as short as one second, but produces output for all constituents for all layers in each segment at a user-chosen time interval, often hourly.
During the initial construction of the USGS model, the hypothesis was developed that macrophytes (rooted aquatic plants) may be an important contributor to the nutrient, $\mathrm{pH}$, and oxygen cycling in the Klamath River; however, no macrophyte field data were available. Further, model development suggested that $\mathrm{pH}$ buffering by organic matter, orthophosphorus, and ammonia, or a combination of these, may be important in this reach, but CE-QUAL-W2 did not include equations to account for those forms of buffering. Thus, the model published in 2011 (Sullivan and others, 2011) did not simulate macrophytes and was not calibrated for $\mathrm{pH}$. This study describes macrophyte field data and the addition of macrophytes to the model, the addition of enhanced $\mathrm{pH}$ buffering to CE-QUAL-W2, and recalibration of the upper Klamath River model for the years 2006-09.

\section{Purpose and Scope}

The purpose of this work was to update the USGS upper Klamath River model by (1) including macrophytes based on data collected in summer and fall (June-October), (2) incorporating dissolved organic matter, phosphoric acid, and ammonia buffering into the simulation of $\mathrm{pH}$, and (3) recalibrating the CE-QUAL-W2 model for 2006-09. The updated model can simulate stage, flow, water velocity, ice cover, water temperature, specific conductance, inorganic suspended sediment, total nitrogen, particulate nitrogen, nitrate, ammonia, total phosphorus, orthophosphorus, particulate carbon, dissolved organic carbon, organic matter in the sediment, three algal groups, three macrophyte groups, dissolved oxygen, and $\mathrm{pH}$.

The model covers the $19.6 \mathrm{mi}(31.5 \mathrm{~km})$ reach of the Klamath River from the end of Link River, near site 11507501, to Keno Dam. This reach includes several point sources as well as inflows from the Klamath Strait Drain and seasonal withdrawals or inflows from the Lost River Diversion Channel and withdrawals through the North and Ady Canals. The purpose of this report is to document the changes to the model and illustrate the importance of macrophytes and $\mathrm{pH}$ buffering in this reach of the Klamath River.

\section{Macrophytes}

Macrophytes participate in the cycles of many water-quality constituents of surface waters including nutrients, organic matter, oxygen, and pH. CE-QUAL-W2 is capable of modeling macrophytes, but before incorporating them into the Link River to Keno Dam model, it was necessary to collect field data on the species present and their distribution spatially and temporally. The macrophyte field work was completed in summer and fall 2011 by a Reclamation field crew. 


\section{Field Methods}

Three macrophyte sampling events in the Link River to Keno Dam reach of the Klamath River were conducted in 2011: June 27 to July 7, August 15 to 19, and October 11 to 13. Cross-section sampling was conducted by boat at mile or half-mile intervals. The sampling proceeded from upstream to downstream for the first and last sampling periods and downstream to upstream for the second sampling period.

At each location the crew sampled macrophytes at both the left and right banks, moving from shore towards mid-channel. Samples were taken at $0.4 \mathrm{~m}, 1.2 \mathrm{~m}, 2 \mathrm{~m}$, to a maximum sampling depth of $2.8 \mathrm{~m}$. In addition to water depth, distance from shore was noted. Macrophytes were sampled with a rake technique (Rich Miller, Portland State University Center for Lakes and Reservoirs, oral commun., May 2011) that had been applied successfully in other studies (Kenow and others, 2007; Cashatt and Bruce, 2009; Owens and others, 2010; Hauxwell and others, 2010). A total of 765 rake samples were collected during the three sampling events. Each sample was collected by lowering a two-sided rake, with depth markings on the handle, to the specified depth, twisting the rake 180 degrees and pulling the macrophyte sample up to the surface. Total percentage of rake head coverage by the macrophytes was estimated (Cashatt and Bruce, 2009). Then macrophytes were removed from the rake head and separated into species. The approximate percentage of rake head coverage for each species was estimated from the total rake head coverage and the prevalence of each species. New species were photographed when first identified. Three Secchi-disk readings were taken at each cross-section location: one mid-channel, one between mid-channel and the left bank, and one between mid-channel and the right bank.

The CE-QUAL-W2 model simulates macrophyte dry-weight concentrations in the river, so dry weights were determined for a subset of samples. First, plant material for an individual species at a selected rake sampling was weighed wet, with sediment rinsed off and excess water removed. That plant material was then air dried for 7 days in the arid Klamath Falls climate, weighed again, then placed in a drying oven at $105^{\circ} \mathrm{C}$ for an additional 8 hours and weighed a final time. Most water weight was lost during air drying, with total weight decreasing an average of 91 percent. Oven drying reduced the weight of the air-dried sample only slightly more, for an average total weight loss from wet to dry of 92 percent. Numerous small snails were dispersed throughout the macrophyte material and were not removed during this analysis; the presence of the snails may cause the macrophyte material in this study to dry differently than pure vegetative material.

A relation between species dry weight and percentage rake coverage was developed for a subset of rake samples, including data from all species except for filamentous green algae:

$$
\text { dry weight }=0.2005 \times \text { rake coverage } \quad R^{2}=0.81
$$

with dry weight in grams and rake coverage determined as a percentage. This relation was then applied to all samples. Dry weights were divided by the sampling rake area to obtain estimates of dry weight biomass per square meter of sediment surface (grams per square meter; $\mathrm{g} / \mathrm{m}^{2}$ ). This macrophyte biomass areal concentration estimate was used to put bounds on modeled macrophyte biomass concentrations during model calibration. Quantitative macrophyte sampling is inherently difficult, due in part to spatial patchiness and temporal variability (Mark Sytsma, Portland State University Center for Lakes and Reservoirs, oral commun., May 2011). Because the data collection occurred during one year, inter-annual variability of macrophyte density and species distribution is not known at this time.

\section{Field Results}

Mid-channel Secchi-disk values were highest in the June-July sampling (fig. 2), averaging $1.3 \mathrm{~m}$, compared to August (averaging $0.8 \mathrm{~m}$ ) and October (averaging $0.6 \mathrm{~m}$ ). Water-column dissolved and particulate organic matter and algae, which contribute to light extinction, increase from spring into summer in this reach (Sullivan and others, 2008, 2009, 2011).

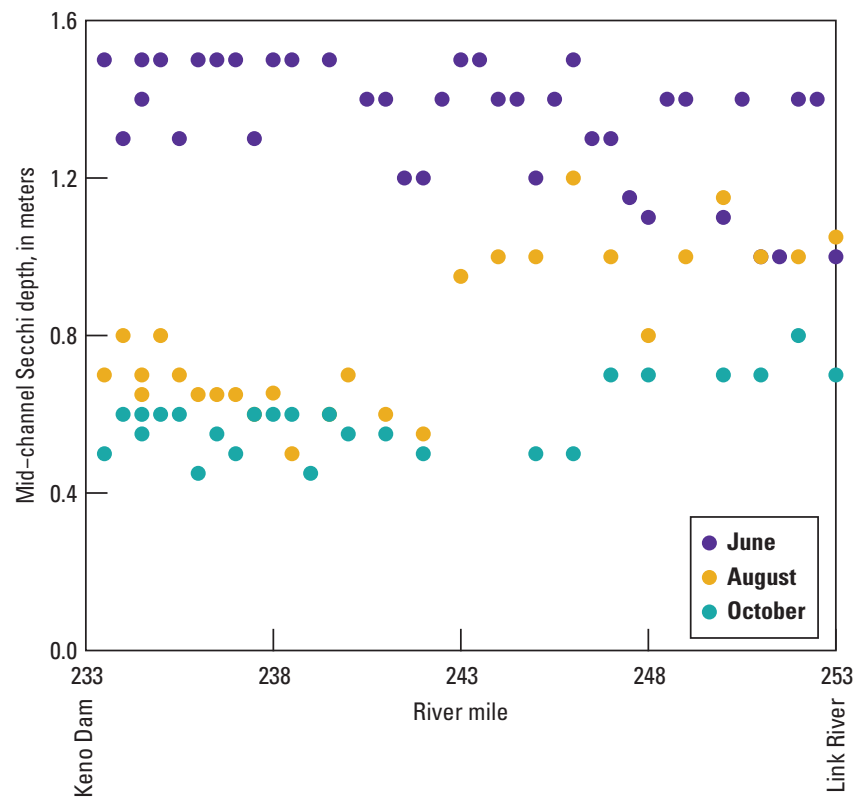

Figure 2. Mid-channel Secchi depth for the June (June 27-July 7), August (August 15-19), and October (October 11-13) 2011 macrophyte sampling events in the Link River to Keno Dam reach of the Klamath River, Oregon. 
Macrophyte species identified during the sampling trips are shown in table 1 . Of these, the four most commonly identified species were curlyleaf pondweed (Potamogeton crispus), small pondweed (Potamogeton pusillus), coontail (Ceratophyllum demersum), and common waterweed (Elodea canadensis). Small pondweed was not distinguished with certainty from the similar leafy pondweed (Potamogeton foliosus); the plant was one of those two thin-leafed pondweeds.

Pondweeds were distributed throughout the reach in June-July, were less common in August, and rare in October (fig. 3). This was expected, since curlyleaf pondweed is a cool weather strategist (Nichols and Shaw, 1986). It can overwinter as an entire plant, flower in early spring, and begin to decline in early summer. The plant is noted to be an indicator species of eutrophic conditions (Nichols and Shaw, 1986). Curlyleaf pondweed is a non-native species and has some competitive advantages over native species in that it begins growing earlier in the year and its wider leaves may shade native pondweeds (Vanessa Morgan, Portland State Center for Lakes and Reservoirs, oral commun., September 2012). Both pondweed species were found throughout the reach, but curlyleaf pondweed biomass was higher in the upstream part of the Link River to Keno Dam reach.

Common waterweed was at its highest density at the furthest downstream section of the reach, near Keno Dam (fig. 3). Like pondweed, common waterweed can overwinter as an entire plant and is an indicator species of eutrophic conditions (Nichols and Shaw, 1986). Coontail also was found in its highest biomass in the lower part of the study reach (fig. 3) and was found in both summer and fall samplings. Coontail has no true roots and either floats freely or is anchored by modified leaves (Hough and others, 1989). Maximum estimated dry weight biomass for any sampled species was $202 \mathrm{~g} / \mathrm{m}^{2}$ for coontail during the August sampling.

All macrophytes were most common in the shallowest near-shore environments, less common at a depth of $2 \mathrm{~m}$, and rarely found in deeper waters. This distribution is likely due to the high light extinction in the reach; substrate differences may also be contributing factors. In the nearby Lost River basin, Eilers (2005) found attached macrophytes uncommon below $1.5 \mathrm{~m}$ and theorized that light extinction was a limiting factor for that depth distribution.

Extensive populations of snails, often $<1 \mathrm{~mm}$, were distributed within the macrophyte plant material and were especially notable in August and October. Snail density and diversity were both high with Physids, Planorbids, and Lymaeids identified within the samples (Robyn Draheim, Portland State University Center for Lakes and Reservoirs, oral commun., September 2011).

Table 1. Submergent species identified at June 27-July 7, August 15-19, and October 11-13, 2011 sampling events in the Link River to Keno Dam reach of the upper Klamath River, Oregon.

[Abbreviation:-, not applicable]

\begin{tabular}{lllc}
\hline \multicolumn{1}{c}{ Common name } & \multicolumn{1}{c}{ Species name } & Origin & $\begin{array}{c}\text { Percent of total } \\
\text { samples with } \\
\text { species present }\end{array}$ \\
\hline Autumnal water-starwort & Callitriche hermaphroditica & native & 0.5 \\
Coontail & Ceratophyllum demersum & native & 27.6 \\
Common waterweed & Elodea canadensis & native & 22.7 \\
Yellow water flag & Iris pseudacorus & non-native & 0.1 \\
Common water nymph & Najas guadalupensis & native & 0.3 \\
Water cress & Nasturtium officinale & native & 0.1 \\
Curlyleaf pondweed & Potamogeton crispus & non-native & 21.0 \\
Small pondweed & Potamogeton pusillus & native & 35.7 \\
Hardstem bulrush & Schoenoplectus acutus & native & 0.7 \\
Giant burweed & Sparganium eurycarpum & native & 0.4 \\
Cattail & Typha sp. & native & 0.1 \\
Horned pondweed & Zannichelia palustris & native & 6.4 \\
Filamentous green algae & & native & 18.7 \\
\hline
\end{tabular}



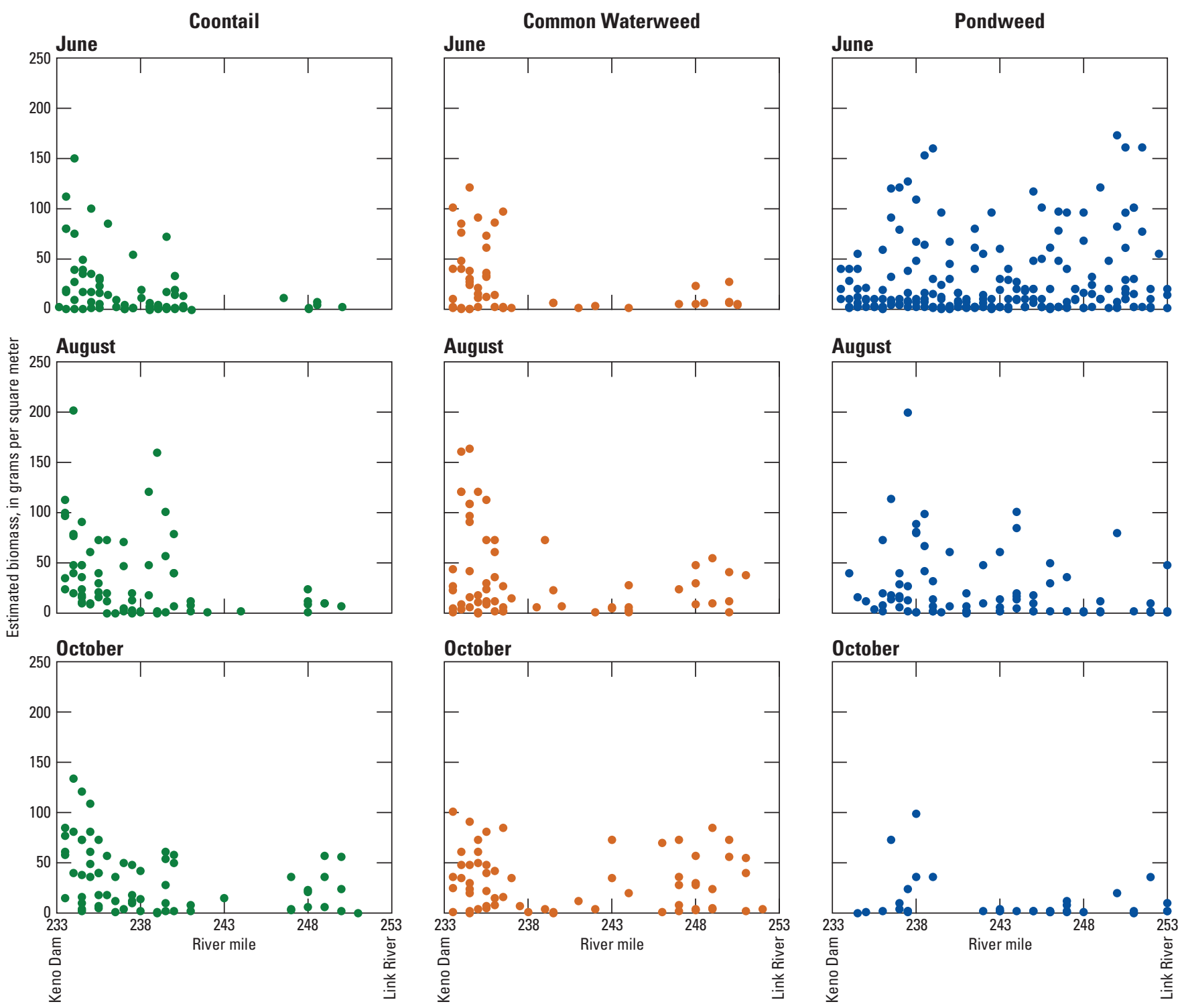

Figure 3. Estimated dry weight biomass for the most commonly identified macrophytes at June (June 27-July 7), August (August 15-19), and October (October 11-13) 2011 sampling events in the Link River to Keno Dam reach of the Klamath River, Oregon. 


\section{Model Initial Conditions}

The default implementation of CE-QUAL-W2, version 3.6, initializes each macrophyte species homogenously across the reach, giving the same density to all cells in the grid. However, field results showed distinct trends in the distribution of macrophytes both longitudinally along the river and with depth. The longitudinal spatial trends probably persist for more than a year, given that some of the macrophyte species observed in the Klamath River can overwinter as entire plants and propagation can occur from existing stem fragments (Nichols and Shaw, 1986). The CE-QUAL-W2 macrophyte code was changed to give the user the option to initialize macrophyte populations with a nonuniform longitudinal and vertical distribution (appendix A). Using this new capability, all cells were initialized on January 1 with a small population of each species, and then selected cells were initialized with higher density. Pondweed was initialized with higher density across all model segments at shallow depths $<2 \mathrm{~m}$. Coontail was initialized with higher density at shallow depths in model segments 65 to 102 (just upstream of the Klamath Strait Drain inflow [segment 69] to Keno Dam [segment 102]). Common waterweed (Elodea canadensis) was initialized at higher densities at shallow depths in segments 86 to 102 (downstream of the KRS12a monitoring site [segment 78] to Keno Dam). After this initialization on day 1, macrophytes were simulated according to the macrophyte model parameters and local conditions.

\section{Model Rates and Coefficients}

The CE-QUAL-W2 macrophyte algorithms consist of one section that simulates water-quality effects and another that simulates hydrodynamic effects. Because hydrodynamics were already simulated well by the original model (Sullivan and others, 2011), macrophyte hydrodynamic effects were turned off in the revised upper Klamath River model through a choice of values for the model parameters CDDRAG, DWV, and ANORM. The water-quality effects of macrophytes were included in the updated model. The model can simulate multiple submerged species of macrophytes. Based on results from the field sampling, the three most prevalent macrophyte groups were incorporated into the upper Klamath River model:

1. Pondweeds

2. Coontail

3. Common waterweed
Macrophyte growth, respiration, and mortality/excretion are simulated by CE-QUAL-W2. Growth is from the channel bottom upwards through model layers and can be limited by light, water temperature, carbon dioxide, ammonia, and orthophosphorus. Nutrients can be obtained from the water column and from the sediment; the fraction obtained from the sediment is set by the user. When nutrients are obtained from the sediment, that nutrient supply is assumed to be infinite. While CE-QUAL-W2 models the growth and water-quality effects of macrophytes well, it is important to remember that some macrophtye ecological effects, such as possible inhibitory effects on algal growth (Koerner and Nicklisch, 2002), are not yet coded into the model.

Rates and coefficients are required for each macrophyte group (table 2). Default CE-QUAL-W2 rates were modified as guided by the characteristics of the species in each group. For instance, the temperature parameters for the pondweed group were adjusted so that maximum growth rates were during spring and early summer, with reduced growth in mid-summer to match the field observation that pondweed density is highest early in the year and declines in summer. Macrophyte senescence is not modeled directly by CE-QUAL-W2, but adjustment of temperature parameters that are tied to mortality can help to simulate such seasonal patterns. Light saturation parameters were reduced from the default values in order to allow for the growth of macrophytes in this light-limited reach of the Klamath River. Macrophytes can adapt to low light conditions by changing their respiration, photosynthetic pigments, and morphology (Barko and Smart, 1981; Barko and others, 1981). The macrophyte respiration oxygen stoichiometry was increased to 1.5 from the default 1.1 to account for respiration from snails (found densely within macrophytes), which was not modeled separately. Because coontail does not have true roots, its parameters were set so that all nutrients were obtained from the water column only; the other two groups were able to obtain nutrients from both the sediment and the water column. Macrophyte growth was not limited by nutrients when the half-saturation constants for nutrient-limited growth were set to zero; other studies and macrophyte models have noted that growth is limited more by light and temperature than by nutrients (Barko and Smart, 1981; Berger and Wells, 2008). 
Table 2. Macrophyte parameters in the updated water-quality model for the Link River to Keno Dam reach of the Klamath River, Oregon.

[Abbreviations: ${ }^{\circ} \mathrm{C}$, degrees Celsius; g/g, gram per gram; $\mathrm{m}^{2} / \mathrm{g}$, square meter per gram; g/m³ , gram per cubic meter; 1/day, per day; POM, particulate organic matter; $\mathrm{W} / \mathrm{m}^{2}$, Watt per square meter]

\begin{tabular}{|c|c|c|c|c|}
\hline Parameter & Pondweed & Coontail & $\begin{array}{c}\text { Common } \\
\text { waterweed }\end{array}$ & Description \\
\hline EXM & 0.005 & 0.005 & 0.005 & Light extinction due to macrophytes, $\mathrm{m}^{2} / \mathrm{g}$ \\
\hline MR & 0.07 & 0.09 & 0.09 & Maximum macrophyte respiration rate, $1 /$ day \\
\hline MM & 0.06 & 0.07 & 0.06 & Maximum macrophyte mortality rate, 1 /day \\
\hline MSAT & 6 & 3 & 7 & Light saturation intensity at maximum photosynthetic rate, $\mathrm{W} / \mathrm{m}^{2}$ \\
\hline MHSC & 0.0 & 0.0 & 0.0 & Macrophyte half-saturation for carbon limited growth, $\mathrm{g} / \mathrm{m}^{3}$ \\
\hline MPOM & 0.7 & 0.7 & 0.7 & Fraction of macrophyte biomass converted to POM when macrophytes die \\
\hline LRPMAC & 0.2 & 0.2 & 0.2 & Fraction of POM which originates as dead macrophytes becoming labile POM \\
\hline PSED & 0.8 & 0.0 & 0.8 & Fraction of phosphorus uptake by macrophytes obtained from sediments \\
\hline NSED & 0.8 & 0.0 & 0.8 & Fraction of nitrogen uptake by macrophytes obtained from sediments \\
\hline MT2 & 15 & 24 & 24 & Upper temperature parameter for rising rate function, ${ }^{\circ} \mathrm{C}$ \\
\hline MT3 & 19 & 27 & 27 & Lower temperature parameter for falling rate function, ${ }^{\circ} \mathrm{C}$ \\
\hline MT4 & 26 & 35 & 35 & Upper temperature parameter for falling rate function, ${ }^{\circ} \mathrm{C}$ \\
\hline MK1 & 0.05 & 0.05 & 0.05 & Fraction of rate at MT1 \\
\hline MK2 & 0.99 & 0.99 & 0.99 & Fraction of rate at MT2 \\
\hline MK3 & 0.99 & 0.99 & 0.99 & Fraction of rate at MT3 \\
\hline MK4 & 0.10 & 0.01 & 0.01 & Fraction of rate at MT4 \\
\hline MP & 0.004 & 0.004 & 0.004 & Stoichiometric equivalent between phosphorus and biomass, g/g \\
\hline MN & 0.054 & 0.054 & 0.054 & Stoichiometric equivalent between nitrogen and biomass, g/g \\
\hline MC & 0.50 & 0.52 & 0.50 & Stoichiometric equivalent between carbon and biomass, g/g \\
\hline O2MR & 1.5 & 1.5 & 1.5 & Oxygen stoichiometry for macrophyte respiration \\
\hline
\end{tabular}

\section{Enhanced pH Buffering and Nonconservative Alkalinity}

In most freshwater systems, alkalinity is dominated by bicarbonate and carbonate; other constituents are either unimportant or have only a minor effect on alkalinity and the shape of the alkalinity titration curve (Hem, 1985; Stumm and Morgan, 1996; Rounds, 2006). In some systems, however, other constituents such as ammonia, organic matter, phosphoric acid, silicic acid, and boric acid, depending on their concentration, can have substantive acid/base properties. None of these other constituents were integrated into the default equations that the unmodified CE-QUAL-W2 model uses to calculate $\mathrm{pH}$. Although neglecting such effects is appropriate for many natural waters, that approach may lead to significant errors in the prediction of $\mathrm{pH}$ under certain conditions.
Dissolved organic matter, ammonia, and orthophosphorus at times are present in sufficiently large concentrations in the upper Klamath River to provide a substantial pH buffering capacity. For the purpose of modeling acid/base behavior, it was assumed that the orthophosphorus measured in the river could be represented by phosphoric acid and its conjugate bases. The necessity to include organic matter, ammonia, and phosphoric acid in the CE-QUAL-W2 $\mathrm{pH}$ equations and code was noted during the initial construction and calibration of the USGS upper Klamath River model (Sullivan and others, 2011), which recommended inclusion of these factors before $\mathrm{pH}$ calibration could be completed. Thus in this study, $\mathrm{pH}$ buffering effects of organic matter, ammonia, and phosphoric acid were incorporated into CE-QUAL-W2 for use in the upper Klamath River model. This required a review of the literature and modification of the CE-QUAL-W2 source code. Source code changes are documented in appendix B. 
In addition, previous versions of CE-QUAL-W2 have assumed that alkalinity is largely unaffected by chemical and biological reactions and responds only to changes in inputs and transport. While alkalinity is largely a conservative quantity, it is not entirely conservative. Reactions such as ammonia nitrification and nitrate denitrification, as well as photosynthesis and respiration, can have small effects on alkalinity. As a result of changes made to this version of CE-QUAL-W2, the user is allowed to specify whether alkalinity is to be simulated as a conservative or a nonconservative quantity.

\section{General Alkalinity Equations}

Alkalinity is a measure of the amount of base that is present in a system relative to a reference solution of carbon dioxide in water. Alkalinity typically is measured through an acidimetric titration of a water sample and subsequent analysis to determine the final equivalence point (see Rounds, 2006, for USGS methods). Alkalinity can be divided into several components, depending on which acid/base constituents are included in its computation:

$$
\mathrm{Alk}=\mathrm{Alk}_{\mathrm{carb}}+\mathrm{Alk}_{\mathrm{am}}+\mathrm{Alk}_{\mathrm{P}}+\mathrm{Alk}_{\mathrm{OM}}+\ldots
$$

where

Alk is the total sample alkalinity,

$\mathrm{Alk}_{\text {carb }}$ is the baseline alkalinity due to carbonic acid species and water,

Alk $_{\mathrm{am}}$ is the alkalinity due to ammonia,

$\mathrm{Alk}_{\mathrm{P}}$ is the alkalinity due to phosphoric acid species,

$\mathrm{Alk}_{\mathrm{OM}}$ is the alkalinity due to organic matter, and

... refers to alkalinity from other species at low concentration and not considered here.

The alkalinity due to carbonic acid and water is straightforward to compute because alkalinity is defined as the excess base relative to a solution of carbon dioxide in water:

$$
\mathrm{Alk}_{\mathrm{carb}}=\left[\mathrm{HCO}_{3}^{-}\right]+2\left[\mathrm{CO}_{3}^{2-}\right]+\left[\mathrm{OH}^{-}\right]-\left[\mathrm{H}^{+}\right]
$$

where the square brackets indicate concentrations of the various species in moles per liter, and alkalinity is in units of equivalents per liter. The derivation of the above equation can be found in many aquatic chemistry textbooks (Pankow, 1991; Stumm and Morgan, 1996; Drever, 1997). For ammonia, because the transition between the acid form (ammonium,
$\left.\mathrm{NH}_{4}^{+}\right)$and the base form $\left(\mathrm{NH}_{3}\right)$ occurs at a $\mathrm{pH}$ of about 9.3, and because the final equivalence point of an alkalinity titration typically occurs below a $\mathrm{pH}$ of 5 , any ammonia that is present in the sample will be titrated with acid and included in the measured alkalinity, resulting in the following contribution:

$$
\mathrm{Alk}_{\mathrm{am}}=\left[\mathrm{NH}_{3}\right]
$$

Phosphoric acid $\left(\mathrm{H}_{3} \mathrm{PO}_{4}\right)$ is a triprotic acid that can exist in four forms, depending on the $\mathrm{pH}$, if the various polyphosphate structures are neglected. When considering how to account for these species in an alkalinity computation, determining which of these species predominate at the $\mathrm{pH}$ of the final equivalence point of an alkalinity titration is necessary. Because the first and second acid dissociations of phosphoric acid occur near $\mathrm{pH} 2.1$ and 7.2, it is reasonable to assume that $\mathrm{H}_{2} \mathrm{PO}_{4}^{-}$is by far the predominant form of phosphoric acid present at the end of an alkalinity titration, which typically is in the $\mathrm{pH}$ range of 5.5-4.2; therefore, the contribution of these species to a measured alkalinity is:

$$
\mathrm{Alk}_{\mathrm{P}}=\left[\mathrm{HPO}_{4}^{2-}\right]+2\left[\mathrm{PO}_{4}^{3-}\right]-\left[\mathrm{H}_{3} \mathrm{PO}_{4}\right]
$$

Finally, the contributions of organic matter to alkalinity must be included. This is not straightforward because natural organic matter consists of large, complex, and largely uncharacterized chemical structures that have multiple acid/ base groups, including a range of carboxylic and phenolic groups of varying acidity. Many researchers have studied the acid/base properties of dissolved organic matter and found that those properties, while not characterized exactly, can be approximately represented through the use of a mixture of multiple simple acids or a distribution of acidities (Perdue and others, 1984; Gherini and others, 1985; Bonn and Fish, 1991; Tipping, 1994). However, many natural organic acids have acidities such that the acid group either would not be titrated or would only be partially titrated in a typical alkalinity titration. This complication can be resolved by assuming that the chemistry of carbonic acid dominates the sample near the final equivalence point, despite the presence of other acid/base species, and thereby is the predominant factor determining the equivalence point of the titration. Historically, many alkalinity titrations were deemed to be complete (at the equivalence point) when the sample had been titrated to a $\mathrm{pH}$ of 4.5 . While this fixed-endpoint technique is no longer the primary method used by many organizations such as the USGS, it remains true that titrations of natural water samples typically result in an equivalence point in the $\mathrm{pH}$ range of 4.2-5.5. 
For all but the most dilute samples, the use of a $\mathrm{pH} 4.5$ equivalence point normally results in only small percentage errors in the computed sample alkalinity. Assuming a $\mathrm{pH}$ 4.5 equivalence point also greatly simplifies the task of determining the contribution of organic matter to alkalinity:

$$
\operatorname{Alk}_{\mathrm{OM}}=\sum_{i=1}^{\mathrm{n}_{\mathrm{a}}}\left(\left[\mathrm{A}_{\mathrm{i}}^{-}\right]_{\text {sample } \mathrm{pH}}-\left[\mathrm{A}_{\mathrm{i}}^{-}\right]_{\mathrm{pH}=4.5}\right)
$$

where

$$
\begin{aligned}
& \mathrm{n}_{\mathrm{a}} \text { is the number of simulated acid groups, } \\
& {\left[\mathrm{A}_{\mathrm{i}}^{-}\right]_{\text {sample } \mathrm{pH}} \text { is the concentration of the base form of }}
\end{aligned}
$$

This concentration difference represents the amount of these bases that would be titrated in an alkalinity titration if that titration were terminated at $\mathrm{pH} 4.5$, and therefore it is a reasonable estimate of the contribution of these acid groups to the sample alkalinity.

Putting all of these terms together, the sample alkalinity can be represented as

$$
\begin{aligned}
\mathrm{Alk}=\left[\mathrm{HCO}_{3}^{-}\right]+ & 2\left[\mathrm{CO}_{3}^{2-}\right]+\left[\mathrm{OH}^{-}\right]-\left[\mathrm{H}^{+}\right]+\left[\mathrm{NH}_{3}\right] \\
& +\left[\mathrm{HPO}_{4}^{2-}\right]+2\left[\mathrm{PO}_{4}^{3-}\right]-\left[\mathrm{H}_{3} \mathrm{PO}_{4}\right] \\
& +\sum_{i=1}^{\mathrm{n}_{\mathrm{a}}}\left(\left[\mathrm{A}_{\mathrm{i}}^{-}\right]-\left[\mathrm{A}_{\mathrm{i}}^{-}\right]_{\mathrm{pH}=4.5}\right)
\end{aligned}
$$

\section{Acid Dissociation Chemistry}

The alkalinity equation (7) can be written only as a function of acid dissociation constants and a few concentrations that are simulated by the CE-QUAL-W2 model. Consider a single monoprotic acid that dissociates and reassociates in the following reaction:

$$
\mathrm{HA} \rightleftarrows \mathrm{H}^{+}+\mathrm{A}^{-}
$$

The acid dissociation constant for this reaction is defined as:

$$
\mathrm{K}_{\mathrm{a}}=\frac{\left\{\mathrm{H}^{+}\right\}\left\{\mathrm{A}^{-}\right\}}{\{\mathrm{HA}\}}
$$

where

$\mathrm{K}_{\mathrm{a}}$ is the acid dissociation constant, and the curly braces indicate the "activity" of the various species in moles per liter.
The activity of a species is approximately the same as its concentration in dilute freshwater samples. Activity corrections for more saline water can be handled through the definition of a mixed acid dissociation constant:

$$
\mathrm{K}_{\mathrm{a}}^{\prime}=\frac{\left\{\mathrm{H}^{+}\right\}\left[\mathrm{A}^{-}\right]}{[\mathrm{HA}]}=\mathrm{K}_{\mathrm{a}} \frac{\gamma_{\mathrm{HA}}}{\gamma_{\mathrm{A}^{-}}}
$$

where

$$
\begin{aligned}
& \gamma_{\mathrm{HA}} \text { is the activity coefficient for HA, and } \\
& \gamma_{\mathrm{A}^{-}} \text {is the activity coefficient for } \mathrm{A}^{-} .
\end{aligned}
$$

Knowing the value of the acid dissociation constant allows the concentration of $\mathrm{A}^{-}$to be written as a function of the total concentration of the acid and base forms of this constituent:

$$
\left[\mathrm{A}^{-}\right]=\mathrm{A}_{\mathrm{T}} \frac{\mathrm{K}_{\mathrm{a}}^{\prime}}{\left\{\mathrm{H}^{+}\right\}+\mathrm{K}_{\mathrm{a}}^{\prime}} \text { where } \mathrm{A}_{\mathrm{T}}=[\mathrm{HA}]+\left[\mathrm{A}^{-}\right]
$$

This equation can be rearranged after realizing that, just as $\mathrm{pH}=-\log _{10}\left\{\mathrm{H}^{+}\right\}$and $\left\{\mathrm{H}^{+}\right\}=10^{-\mathrm{pH}}$,

$$
\mathrm{pK}_{\mathrm{a}}^{\prime}=-\log _{10}\left(\mathrm{~K}_{\mathrm{a}}^{\prime}\right) \text { and } \mathrm{K}_{\mathrm{a}}^{\prime}=10^{-\mathrm{pK}_{\mathrm{a}}^{\prime}}
$$

The concentration of $\mathrm{A}^{-}$then can be written in terms of $\mathrm{pH}$ and the acid group's $\mathrm{pK}_{\mathrm{a}}^{\prime}$ :

$$
\left[\mathrm{A}^{-}\right]=\mathrm{A}_{\mathrm{T}} \frac{\mathrm{K}_{\mathrm{a}}^{\prime}}{\left\{\mathrm{H}^{+}\right\}+\mathrm{K}_{\mathrm{a}}^{\prime}}=\mathrm{A}_{\mathrm{T}} \frac{1}{1+\frac{\left\{\mathrm{H}^{+}\right\}}{\mathrm{K}_{\mathrm{a}}^{\prime}}}=\mathrm{A}_{\mathrm{T}} \frac{1}{1+10^{\left(\mathrm{pK}_{\mathrm{a}}^{\prime}-\mathrm{pH}\right)}}
$$

For organic matter that is represented as a mixture of monoprotic acids, this representation is particularly useful because it can be evaluated easily for both the sample $\mathrm{pH}$ and a $\mathrm{pH}$ of 4.5 , which is the assumed $\mathrm{pH}$ of the endpoint of the alkalinity titration.

For a diprotic acid such as carbonic acid, it is relatively simple to define similar functions. The total inorganic carbon concentration is given by:

$$
\mathrm{C}_{\mathrm{T}}=\left[\mathrm{H}_{2} \mathrm{CO}_{3}^{*}\right]+\left[\mathrm{HCO}_{3}^{-}\right]+\left[\mathrm{CO}_{3}^{2-}\right]
$$

where the first term includes carbonic acid as well as dissolved carbon dioxide:

$$
\left[\mathrm{H}_{2} \mathrm{CO}_{3}^{*}\right]=\left[\mathrm{H}_{2} \mathrm{CO}_{3}\right]+\left[\mathrm{CO}_{2}\right]_{(\mathrm{aq})}
$$

Mass balances as well as use of the acid dissociation constants reveal that: 


$$
\begin{aligned}
& {\left[\mathrm{H}_{2} \mathrm{CO}_{3}^{*}\right]=\mathrm{C}_{\mathrm{T}} \frac{\left\{\mathrm{H}^{+}\right\}^{2}}{\left\{\mathrm{H}^{+}\right\}^{2}+\mathrm{K}_{1}^{\prime}\left\{\mathrm{H}^{+}\right\}+\mathrm{K}_{1}^{\prime} \mathrm{K}_{2}^{\prime}}} \\
& {\left[\mathrm{HCO}_{3}^{-}\right]=\mathrm{C}_{\mathrm{T}} \frac{\mathrm{K}_{1}^{\prime}\left\{\mathrm{H}^{+}\right\}}{\left\{\mathrm{H}^{+}\right\}^{2}+\mathrm{K}_{1}^{\prime}\left\{\mathrm{H}^{+}\right\}+\mathrm{K}_{1}^{\prime} \mathrm{K}_{2}^{\prime}}} \\
& {\left[\mathrm{CO}_{3}^{2-}\right]=\mathrm{C}_{\mathrm{T}} \frac{\mathrm{K}_{1}^{\prime} \mathrm{K}_{2}^{\prime}}{\left\{\mathrm{H}^{+}\right\}^{2}+\mathrm{K}_{1}^{\prime}\left\{\mathrm{H}^{+}\right\}+\mathrm{K}_{1}^{\prime} \mathrm{K}_{2}^{\prime}}}
\end{aligned}
$$

where the acid dissociation constants of carbonic acid are given by:

$$
\begin{gathered}
\mathrm{K}_{1}^{\prime}=\frac{\left\{\mathrm{H}^{+}\right\}\left[\mathrm{HCO}_{3}^{-}\right]}{\left[\mathrm{H}_{2} \mathrm{CO}_{3}^{*}\right]}=\mathrm{K}_{1} \frac{\gamma_{\mathrm{H}_{2} \mathrm{CO}_{3}^{*}}}{\gamma_{\mathrm{HCO}_{3}^{-}}} \text {where } \mathrm{K}_{1}=\frac{\left\{\mathrm{H}^{+}\right\}\left\{\mathrm{HCO}_{3}^{-}\right\}}{\left\{\mathrm{H}_{2} \mathrm{CO}_{3}^{*}\right\}} \\
\mathrm{K}_{2}^{\prime}=\frac{\left\{\mathrm{H}^{+}\right\}\left[\mathrm{CO}_{3}^{2-}\right]}{\left[\mathrm{HCO}_{3}^{-}\right]}=\mathrm{K}_{2} \frac{\gamma_{\mathrm{HCO}_{3}^{-}}}{\gamma_{\mathrm{CO}_{3}^{2-}}} \text { where } \mathrm{K}_{2}=\frac{\left\{\mathrm{H}^{+}\right\}\left\{\mathrm{CO}_{3}^{2-}\right\}}{\left\{\mathrm{HCO}_{3}^{-}\right\}}
\end{gathered}
$$

Similar relations can be written for ammonia:

$$
\begin{gathered}
{\left[\mathrm{NH}_{3}\right]=\mathrm{N}_{\mathrm{T}} \frac{\mathrm{K}_{\mathrm{am}}^{\prime}}{\left\{\mathrm{H}^{+}\right\}+\mathrm{K}_{\mathrm{am}}^{\prime}} \text { where } \mathrm{N}_{\mathrm{T}}=\left[\mathrm{NH}_{4}^{+}\right]+\left[\mathrm{NH}_{3}\right]} \\
\mathrm{K}_{\mathrm{am}}^{\prime}=\frac{\left\{\mathrm{H}^{+}\right\}\left[\mathrm{NH}_{3}\right]}{\left[\mathrm{NH}_{4}^{+}\right]}=\mathrm{K}_{\mathrm{am}} \frac{\gamma_{\mathrm{NH}_{4}^{+}}}{\gamma_{\mathrm{NH}_{3}}} \text { where } \mathrm{K}_{\mathrm{am}}=\frac{\left\{\mathrm{H}^{+}\right\}\left\{\mathrm{NH}_{3}\right\}}{\left\{\mathrm{NH}_{4}^{+}\right\}}
\end{gathered}
$$

For phosphoric acid, the relevant equations are:

$$
\begin{gathered}
\mathrm{P}_{\mathrm{T}}=\left[\mathrm{H}_{3} \mathrm{PO}_{4}\right]+\left[\mathrm{H}_{2} \mathrm{PO}_{4}^{-}\right]+\left[\mathrm{HPO}_{4}^{2-}\right]+\left[\mathrm{PO}_{4}^{3-}\right] \\
{\left[\mathrm{H}_{3} \mathrm{PO}_{4}\right]=\mathrm{P}_{\mathrm{T}} \frac{\left\{\mathrm{H}^{+}\right\}^{3}}{\left\{\mathrm{H}^{+}\right\}^{3}+\mathrm{K}_{\mathrm{P} 1}^{\prime}\left\{\mathrm{H}^{+}\right\}^{2}+\mathrm{K}_{\mathrm{P} 1}^{\prime} \mathrm{K}_{\mathrm{P} 2}^{\prime}\left\{\mathrm{H}^{+}\right\}+\mathrm{K}_{\mathrm{P} 1}^{\prime} \mathrm{K}_{\mathrm{P} 2}^{\prime} \mathrm{K}_{\mathrm{P} 3}^{\prime}}} \\
{\left[\mathrm{H}_{2} \mathrm{PO}_{4}^{-}\right]=\mathrm{P}_{\mathrm{T}} \frac{\mathrm{K}_{\mathrm{P} 1}^{\prime}\left\{\mathrm{H}^{+}\right\}^{2}}{\left\{\mathrm{H}^{+}\right\}^{3}+\mathrm{K}_{\mathrm{P} 1}^{\prime}\left\{\mathrm{H}^{+}\right\}^{2}+\mathrm{K}_{\mathrm{P} 1}^{\prime} \mathrm{K}_{\mathrm{P} 2}^{\prime}\left\{\mathrm{H}^{+}\right\}+\mathrm{K}_{\mathrm{P} 1}^{\prime} \mathrm{K}_{\mathrm{P} 2}^{\prime} \mathrm{K}_{\mathrm{P} 3}^{\prime}}} \\
{\left[\mathrm{HPO}_{4}^{2-}\right]=\mathrm{P}_{\mathrm{T}} \frac{\mathrm{K}_{\mathrm{P} 1}^{\prime} \mathrm{K}_{\mathrm{P} 2}^{\prime}\left\{\mathrm{H}^{+}\right\}}{\left\{\mathrm{H}^{+}\right\}^{3}+\mathrm{K}_{\mathrm{P} 1}^{\prime}\left\{\mathrm{H}^{+}\right\}^{2}+\mathrm{K}_{\mathrm{P} 1}^{\prime} \mathrm{K}_{\mathrm{P} 2}^{\prime}\left\{\mathrm{H}^{+}\right\}+\mathrm{K}_{\mathrm{P} 1}^{\prime} \mathrm{K}_{\mathrm{P} 2}^{\prime} \mathrm{K}_{\mathrm{P} 3}^{\prime}}}
\end{gathered}
$$




$$
\begin{gathered}
{\left[\mathrm{PO}_{4}^{3-}\right]=\mathrm{P}_{\mathrm{T}} \frac{\mathrm{K}_{\mathrm{P} 1}^{\prime} \mathrm{K}_{\mathrm{P} 2}^{\prime} \mathrm{K}_{\mathrm{P} 3}^{\prime}}{\left\{\mathrm{H}^{+}\right\}^{3}+\mathrm{K}_{\mathrm{P} 1}^{\prime}\left\{\mathrm{H}^{+}\right\}^{2}+\mathrm{K}_{\mathrm{P} 1}^{\prime} \mathrm{K}_{\mathrm{P} 2}^{\prime}\left\{\mathrm{H}^{+}\right\}+\mathrm{K}_{\mathrm{P} 1}^{\prime} \mathrm{K}_{\mathrm{P} 2}^{\prime} \mathrm{K}_{\mathrm{P} 3}^{\prime}}} \\
\mathrm{K}_{\mathrm{P} 1}^{\prime}=\frac{\left\{\mathrm{H}^{+}\right\}\left[\mathrm{H}_{2} \mathrm{PO}_{4}^{-}\right]}{\left[\mathrm{H}_{3} \mathrm{PO}_{4}\right]}=\mathrm{K}_{\mathrm{P} 1} \frac{\gamma_{\mathrm{H}_{3} \mathrm{PO}_{4}}}{\gamma_{\mathrm{H}_{2} \mathrm{PO}_{4}^{-}}} \text {where } \mathrm{K}_{\mathrm{P} 1}=\frac{\left\{\mathrm{H}^{+}\right\}\left\{\mathrm{H}_{2} \mathrm{PO}_{4}^{-}\right\}}{\left\{\mathrm{H}_{3} \mathrm{PO}_{4}\right\}} \\
\mathrm{K}_{\mathrm{P} 2}^{\prime}=\frac{\left\{\mathrm{H}^{+}\right\}\left[\mathrm{HPO}_{4}^{2-}\right]}{\left[\mathrm{H}_{2} \mathrm{PO}_{4}^{-}\right]}=\mathrm{K}_{\mathrm{P} 2} \frac{\gamma_{\mathrm{H}_{2} \mathrm{PO}_{4}^{-}}}{\gamma_{\mathrm{HPO}_{4}^{2-}}} \text { where } \mathrm{K}_{\mathrm{P} 2}=\frac{\left\{\mathrm{H}^{+}\right\}\left\{\mathrm{HPO}_{4}^{2-}\right\}}{\left\{\mathrm{H}_{2} \mathrm{PO}_{4}^{-}\right\}} \\
\mathrm{K}_{\mathrm{P} 3}^{\prime}=\frac{\left\{\mathrm{H}^{+}\right\}\left[\mathrm{PO}_{4}^{3-}\right]}{\left[\mathrm{HPO}_{4}^{2-}\right]}=\mathrm{K}_{\mathrm{P} 3} \frac{\gamma_{\mathrm{HPO}_{4}^{2-}}}{\gamma_{\mathrm{PO}_{4}^{3-}}} \text { where } \mathrm{K}_{\mathrm{P} 3}=\frac{\left\{\mathrm{H}^{+}\right\}\left\{\mathrm{PO}_{4}^{3-}\right\}}{\left\{\mathrm{HPO}_{4}^{2-}\right\}}
\end{gathered}
$$

Finally, for water the acid dissociation constant and relevant equations are:

$$
\begin{gathered}
\mathrm{K}_{\mathrm{w}}^{\prime}=\left\{\mathrm{H}^{+}\right\}\left[\mathrm{OH}^{-}\right]=\mathrm{K}_{\mathrm{w}} / \gamma_{\mathrm{OH}^{-}} \text {where } \mathrm{K}_{\mathrm{w}}=\left\{\mathrm{H}^{+}\right\}\left\{\mathrm{OH}^{-}\right\} \\
{\left[\mathrm{OH}^{-}\right]=\mathrm{K}_{\mathrm{w}}^{\prime} /\left\{\mathrm{H}^{+}\right\} \text {and }\left[\mathrm{H}^{+}\right]=\left\{\mathrm{H}^{+}\right\} / \gamma_{\mathrm{H}^{+}}}
\end{gathered}
$$

\section{Final Equation of Alkalinity with Enhanced pH Buffering}

Substituting relations for the various species concentrations into the master equation for sample alkalinity results in the following equation:

$$
\begin{aligned}
\text { Alk }= & \mathrm{C}_{\mathrm{T}} \frac{\mathrm{K}_{1}^{\prime}\left\{\mathrm{H}^{+}\right\}+2 \mathrm{~K}_{1}^{\prime} \mathrm{K}_{2}^{\prime}}{\left\{\mathrm{H}^{+}\right\}^{2}+\mathrm{K}_{1}^{\prime}\left\{\mathrm{H}^{+}\right\}+\mathrm{K}_{1}^{\prime} \mathrm{K}_{2}^{\prime}}+\frac{\mathrm{K}_{\mathrm{w}}^{\prime}}{\left\{\mathrm{H}^{+}\right\}}-\frac{\left\{\mathrm{H}^{+}\right\}}{\gamma_{\mathrm{H}^{+}}}+\mathrm{N}_{\mathrm{T}} \frac{\mathrm{K}_{\mathrm{am}}^{\prime}}{\left\{\mathrm{H}^{+}\right\}+\mathrm{K}_{\mathrm{am}}^{\prime}} \\
& +\mathrm{P}_{\mathrm{T}}\left(\frac{\mathrm{K}_{\mathrm{P} 1}^{\prime} \mathrm{K}_{\mathrm{P} 2}^{\prime}\left\{\mathrm{H}^{+}\right\}+2 \mathrm{~K}_{\mathrm{P} 1}^{\prime} \mathrm{K}_{\mathrm{P} 2}^{\prime} \mathrm{K}_{\mathrm{P} 3}^{\prime}-\left\{\mathrm{H}^{+}\right\}^{3}}{\left\{\mathrm{H}^{+}\right\}^{3}+\mathrm{K}_{\mathrm{P} 1}^{\prime}\left\{\mathrm{H}^{+}\right\}^{2}+\mathrm{K}_{\mathrm{P} 1}^{\prime} \mathrm{K}_{\mathrm{P} 2}^{\prime}\left\{\mathrm{H}^{+}\right\}+\mathrm{K}_{\mathrm{P} 1}^{\prime} \mathrm{K}_{\mathrm{P} 2}^{\prime} \mathrm{K}_{\mathrm{P} 3}^{\prime}}\right) \\
& +\mathrm{A}_{\mathrm{T}} \sum_{i=1}^{\mathrm{n}_{\mathrm{a}}} \delta_{i}\left(\frac{1}{1+10^{\left(\mathrm{pK}_{\mathrm{a}}^{\prime}-\mathrm{pH}\right)}}-\frac{1}{1+10^{\left(\mathrm{pK}_{\mathrm{a}}^{\prime}-4.5\right)}}\right)
\end{aligned}
$$

where

$A_{T}$ is the total concentration of organic carbon in moles per liter, and

$\delta_{i} \quad$ values represent the site density for acid group $i$ in units of moles of acid groups per mole of carbon.

Without the enhanced buffering by ammonia, phosphoric acid, and organic matter, the equation would be far simpler, including only the terms before $\mathrm{N}_{\mathrm{T}}$. 


\section{Acid Dissociation Constants for Water, Carbonic Acid, Ammonium, and Phosphoric Acid}

The acid dissociation constants for water, carbonic acid, ammonium, and phosphoric acid can be represented as a function of water temperature according to the following equation:

$$
\log _{10}(\mathrm{~K})=a_{1}+a_{2} \mathrm{~T}+\frac{a_{3}}{\mathrm{~T}}+a_{4} \log _{10}(\mathrm{~T})+\frac{a_{5}}{\mathrm{~T}^{2}}
$$

where

$\mathrm{T}$ is the absolute water temperature in kelvin

$$
\left(\mathrm{T}=\mathrm{t}\left({ }^{\circ} \mathrm{C}\right)+273.15\right) \text {, and }
$$

the coefficients are given by the values in table 3 .

These equations generally predict the values of the various acid dissociation constants to within at least three significant digits relative to published measurements.

\section{Acid Dissociation Constants and Site Densities for Organic Matter}

When using the enhanced $\mathrm{pH}$ buffering modifications to CE-QUAL-W2 for organic matter, the model requires the user to provide the number of acid groups $\left(\mathrm{n}_{\mathrm{a}}\right)$ used to represent the acid/base properties of the organic matter, the site density for each of those groups, and their pK values.
The user can specify either an explicit mixture of monoprotic acids, or a Gaussian distribution of monoprotic acids that are characterized by a mean $\mathrm{pK}$ value and a standard deviation around that mean. The input options are described with the code modifications in appendix B.

If the user specifies that a distribution of organic acid groups is to be used, then the model interprets the number of acid groups as the number of distributions to simulate. For example, the user could specify two groups, where one group is used to represent carboxylic acids with a mean pK of 4.5 and a standard deviation around that mean of 1.2, and a second group to represent phenolic groups with a mean pK of 9.6 and a standard deviation around that mean of 1.0. The model then constructs Gaussian distributions of those $\mathrm{pK}$ values from 0 to 14 and sums them together to assign a distribution of site densities. A Gaussian distribution of $\mathrm{pK}$ values with a mean $\mu$ and standard deviation $\sigma$ is defined by the following equation:

$$
f_{\mathrm{j}}=\frac{1}{\sigma \sqrt{2 \pi}} \exp \left[-\frac{\left(\mathrm{pK}_{\mathrm{j}}-\mu\right)^{2}}{2 \sigma^{2}}\right] \mathrm{dpK}
$$

where

$f_{\mathrm{j}}$ is the fraction of organic matter ligands occurring in the interval of $\mathrm{dpK}$ and characterized by an acid dissociation constant $\mathrm{pK}_{\mathrm{j}}$ centered in the interval dpK.

Table 3. Acid dissociation constants for water, carbonic acid, ammonium, and phosphoric acid used in the model of the Link River to Keno Dam reach of the Klamath River, Oregon.

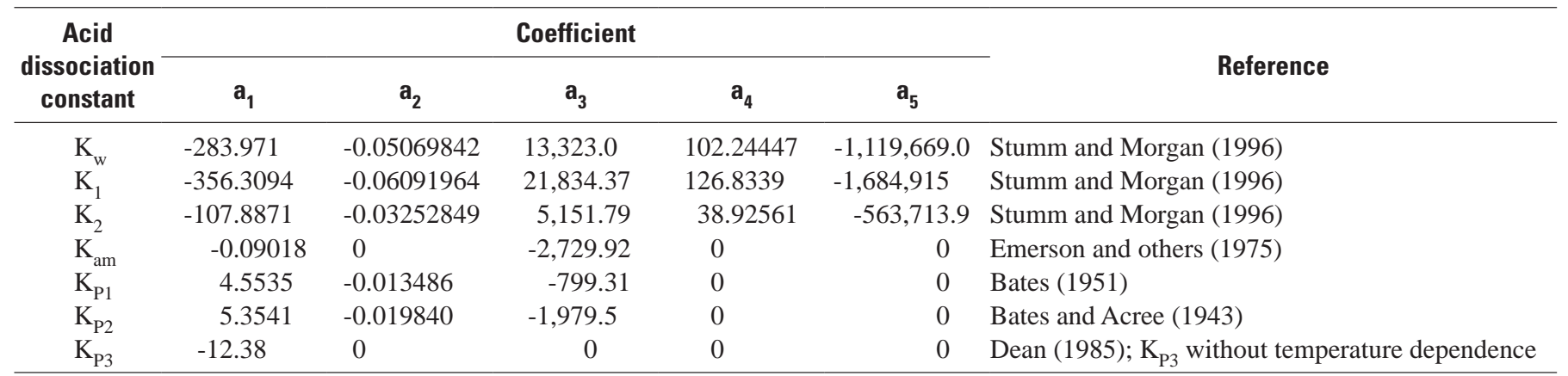


The model truncates this distribution by considering $27 \mathrm{pK}_{\mathrm{j}}$ values from 0.5 to 13.5 at intervals of 0.5 . To account for the truncation, the above equation is normalized such that:

$$
\begin{gathered}
f_{\mathrm{j}}=\frac{\frac{1}{\sigma \sqrt{2 \pi}} \exp \left[-\frac{\left(\mathrm{pK}_{\mathrm{j}}-\mu\right)^{2}}{2 \sigma^{2}}\right] \mathrm{dpK}}{\sum_{\mathrm{n}}\left(\frac{1}{\sigma \sqrt{2 \pi}} \exp \left[-\frac{\left(\mathrm{pK}_{\mathrm{n}}-\mu\right)^{2}}{2 \sigma^{2}}\right] \mathrm{dpK}\right)} \\
=\frac{\exp \left[-\frac{\left(\mathrm{pK}_{\mathrm{j}}-\mu\right)^{2}}{2 \sigma^{2}}\right]}{\sum_{\mathrm{n}}\left(\exp \left[-\frac{\left(\mathrm{pK}_{\mathrm{n}}-\mu\right)^{2}}{2 \sigma^{2}}\right]\right)}
\end{gathered}
$$

where

n goes from 1 to 27 , and the $\mathrm{pK}_{\mathrm{n}}$ values range from 0.5 to 13.5 at intervals of 0.5 .
A truncated Gaussian distribution of these fractions is computed for each of the user-defined distributions ( $i=1$ to $\mathrm{n}_{\mathrm{a}}$ ), and those distributions are then summed to determine the final site density for the 27 simulated $\mathrm{pK}_{\mathrm{j}}$ values (fig. 4). The site density for each of the 27 acid groups, therefore, is:

$$
\delta_{\mathrm{j}}=\sum_{i=1}^{\mathrm{n}_{\mathrm{a}}} \delta_{i} f_{\mathrm{j}}=\sum_{i=1}^{\mathrm{n}_{\mathrm{a}}}\left(\delta_{i} \frac{\exp \left[-\frac{\left(\mathrm{pK}_{\mathrm{j}}-\mu_{\mathrm{i}}\right)^{2}}{2 \sigma_{\mathrm{i}}^{2}}\right]}{\sum_{\mathrm{n}}\left(\exp \left[-\frac{\left(\mathrm{pK}_{\mathrm{n}}-\mu_{\mathrm{i}}\right)^{2}}{2 \sigma_{\mathrm{i}}^{2}}\right]\right)}\right)
$$

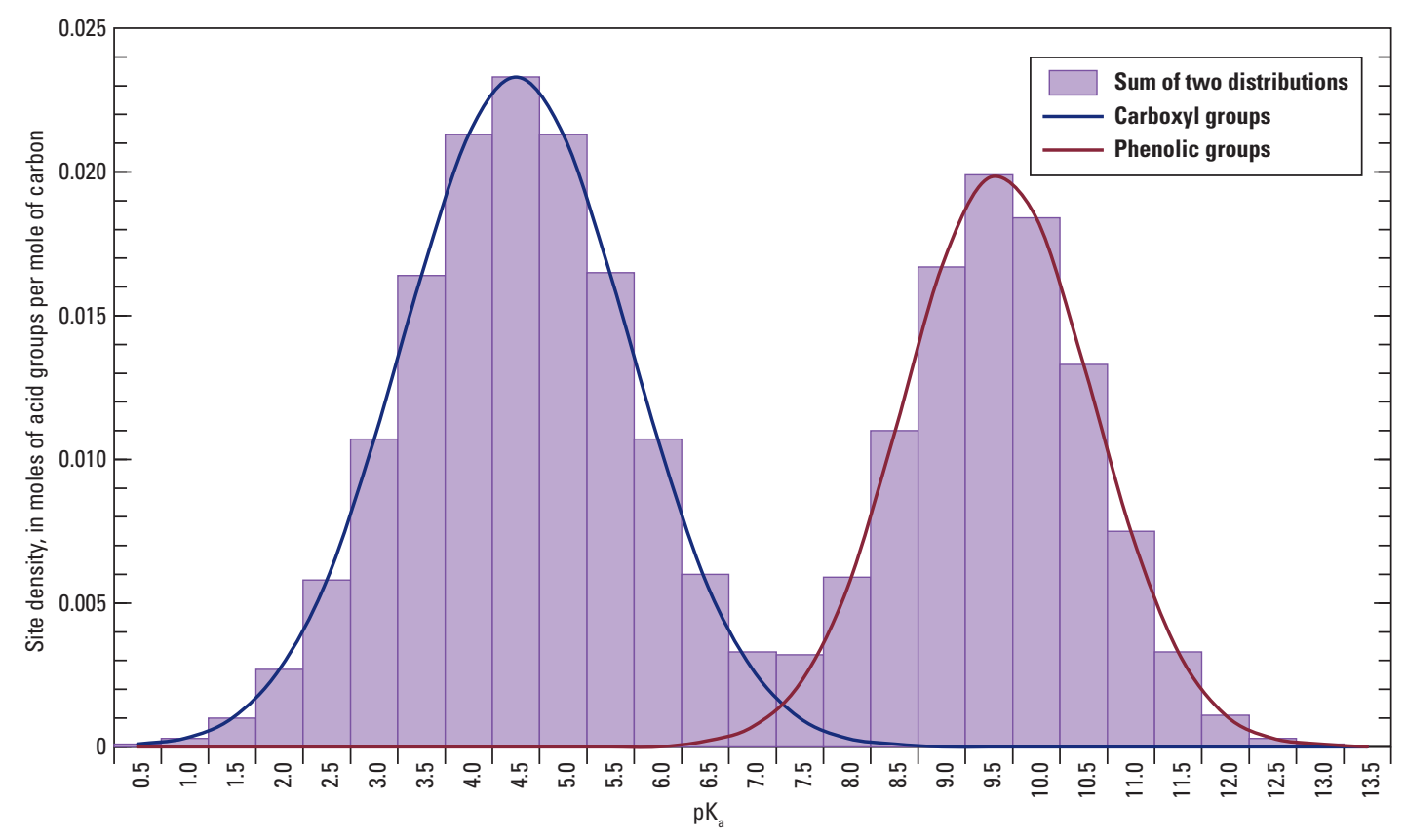

Figure 4. Summation of site densities for two hypothetical Gaussian distributions of $\mathrm{pK}_{\mathrm{a}}$ values. 


\section{Theoretical Alkalinity Titration Curves}

Theoretical alkalinity titration curves can be compared to measured titration curves to derive the number of organic acid groups and their site density and $\mathrm{pK}_{\mathrm{a}}$ values for use as model parameters. During an acidimetric titration, small increments of a known concentration of acid are added to the sample, and the $\mathrm{pH}$ after each addition is recorded. Each increment of acid decreases the alkalinity of the original sample until it becomes zero at the final equivalence point. A simple mass balance indicates that:

$$
\operatorname{Alk}_{\mathrm{t}}=\frac{\mathrm{V}_{\mathrm{o}} \mathrm{Alk}_{\mathrm{o}}-\mathrm{V}_{\mathrm{t}} \mathrm{C}_{\mathrm{a}}}{\left(\mathrm{V}_{\mathrm{t}}+\mathrm{V}_{\mathrm{o}}\right)}
$$

where

$\mathrm{Alk}_{\mathrm{t}}$ is the alkalinity at any time during the titration,

$\mathrm{Alk}_{\mathrm{o}}$ is the original sample alkalinity,

$\mathrm{C}_{\mathrm{a}}$ is the concentration (normality) of the acid titrant,

$\mathrm{V}_{\mathrm{o}}$ is the original sample volume, and

$\mathrm{V}_{\mathrm{t}}$ is the total volume of acid added at any point during the titration.

This equation can be combined with the equation for alkalinity above, using an assumption that the acid titrant does not include any carbonates, phosphates, ammonium, or organic matter, and then solved for the volume of acid added as a function of $\mathrm{pH}$ to produce a theoretical titration curve:

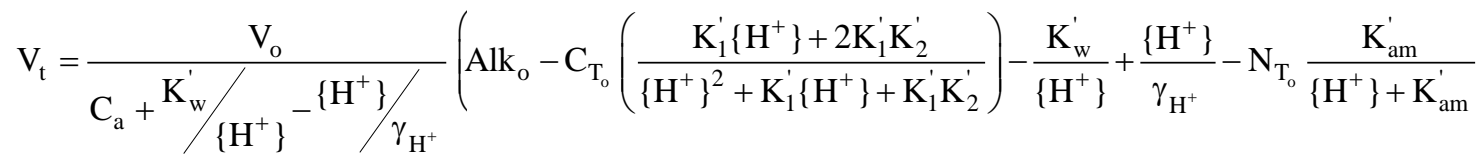

$$
\begin{aligned}
& \left.-\mathrm{P}_{\mathrm{T}_{\mathrm{o}}}\left(\frac{\mathrm{K}_{\mathrm{P} 1}^{\prime} \mathrm{K}_{\mathrm{P} 2}^{\prime}\left\{\mathrm{H}^{+}\right\}+2 \mathrm{~K}_{\mathrm{P} 1}^{\prime} \mathrm{K}_{\mathrm{P} 2}^{\prime} \mathrm{K}_{\mathrm{P} 3}^{\prime}-\left\{\mathrm{H}^{+}\right\}^{3}}{\left\{\mathrm{H}^{+}\right\}^{3}+\mathrm{K}_{\mathrm{P} 1}^{\prime}\left\{\mathrm{H}^{+}\right\}^{2}+\mathrm{K}_{\mathrm{P} 1}^{\prime} \mathrm{K}_{\mathrm{P} 2}^{\prime}\left\{\mathrm{H}^{+}\right\}+\mathrm{K}_{\mathrm{P} 1}^{\prime} \mathrm{K}_{\mathrm{P} 2}^{\prime} \mathrm{K}_{\mathrm{P} 3}^{\prime}}\right)-\mathrm{A}_{\mathrm{T}_{\mathrm{o}}} \sum_{i=1}^{\mathrm{n}_{\mathrm{a}}} \delta_{i}\left(\frac{1}{\left.1+10^{\left(\mathrm{pK}_{\mathrm{a}}^{\prime}\right.}-\mathrm{pH}\right)}-\frac{1}{1+10^{\left(\mathrm{pK}_{\mathrm{ai}}^{\prime}-4.5\right)}}\right)\right)
\end{aligned}
$$

where the "o" subscripts on Alk, $\mathrm{C}_{\mathrm{T}}, \mathrm{N}_{\mathrm{T}}, \mathrm{P}_{\mathrm{T}}$, and $\mathrm{A}_{\mathrm{T}}$ indicate the concentrations in the original sample prior to the beginning of the titration.

If the concentrations of ammonia-plus-ammonium $\left(\mathrm{N}_{\mathrm{T}}\right)$, soluble reactive phosphorus $\left(\mathrm{P}_{\mathrm{T}}\right)$, and organic carbon $\left(\mathrm{A}_{\mathrm{T}}\right)$ in the original sample are known, then this theoretical titration curve can be used to fit a set of measured titration curves to determine the set of $\mathrm{n}_{\mathrm{a}}, \delta_{\mathrm{i}}$, and $\mathrm{pK}_{\mathrm{a}}$ values that best represent the contributions of organic matter to the sample alkalinity. 


\section{Optimization of Organic Matter Parameters}

An optimization program was written to find the set of site density and $\mathrm{pK}$ values for dissolved organic matter that provide the best fit for a set of 24 experimentally measured titration curves for water samples $(0.45 \mu \mathrm{m}$ filtered $)$ collected from Link River, Klamath River at Miller Island (two depths), Klamath River at Keno (two depths), and the Klamath Strait Drain in June, July, August, and September 2007. Those samples also supported an investigation of biochemical oxygen demand in the Klamath River (Sullivan and others, 2010). Alkalinity titrations for these samples were performed according to USGS protocols (Rounds, 2006), and split samples were sent to the USGS National Water Quality Laboratory to determine the concentrations of ammonia-plus-ammonium and soluble reactive phosphorus. Split samples were sent to a USGS organic carbon laboratory in Boulder, Colorado for analysis of dissolved organic carbon concentrations. Titration curves were analyzed using the USGS Alkalinity Calculator (http://or.water.usgs.gov/ alk/) to determine sample alkalinity; results from many samples included a warning message that the shape of the titration curve was not entirely consistent with the shape of a theoretical titration curve based only on the chemistry of carbonic acid. This suggested that some other constituent (other than hydroxide, bicarbonate, and carbonate) had acid/ base properties and was being titrated.

An iterative approach was implemented in which a set of site density and $\mathrm{pK}$ values was chosen, the total inorganic carbon concentration for each sample was computed using equation 42 provided below, and theoretical $V_{t}$ values were computed for every $\mathrm{pH}$ in the experimental alkalinity titrations. The mean sum of squared differences between the experimental and theoretical $V_{t}$ values was computed for each individual titration, and then the mean squared difference was computed for the set of all 24 titrations.

Using that mean squared difference as an objective function to minimize, the optimization program utilized Powell's conjugate direction-set method as described by Press and others (1989) to find the parameter values that provided the best fit to the experimental titration curves. Because the parameter space can include local minima for the objective function, an attempt was made to find the global minimum and therefore the best fit to the data by running the optimization program 100 times with a wide variety of randomized initial parameter values. Results from the 100 optimizations then were analyzed to determine the best set of parameter values.

Two sets of optimizations were attempted. In the first, it was assumed that the acid groups associated with dissolved organic matter could be approximated with two Gaussian distributions of $\mathrm{pK}_{\mathrm{a}}$ values —one to represent carboxylic acid groups and one to represent phenolic or amine groups, after the method of Perdue and others (1984). The carboxylic group was likely to have a mean $\mathrm{pK}_{\mathrm{a}}$ in the range of 3.5-6, while the phenolic group was likely to have a mean $\mathrm{pK}_{\mathrm{a}}$ in the range of 9-11. Note that the algorithm programmed into CE-QUAL-W2 (see appendix B for code changes), as well as the algorithm used in the optimization routine, uses a truncated Gaussian distribution $\left(0.5 \leq \mathrm{pK}_{\mathrm{a}} \leq 13.5\right)$ and discretizes the distribution at 0.5 unit intervals; a smoother version could be used, but this coarser representation of the distribution should be adequate and is computationally faster.

Setting $n_{a}$ to 2, the optimization program was asked to find the best values for six parameters: two site densities, two mean $\mathrm{pK}_{\mathrm{a}}$ values, and a standard deviation about each of the two mean $\mathrm{pK}_{\mathrm{a}}$ values. After 100 optimizations with different initial conditions, the results yielded good information to set the mean $\mathrm{pK}_{\mathrm{a}}$ values to 5.50 and 9.74 , but the standard deviation and site density for the phenolic group proved more difficult to optimize.

The problem with characterizing the phenolic groups is that the experimental titration curves begin at the $\mathrm{pH}$ of the sample and then decrease as acid is added. The highest $\mathrm{pH}$ from the 24 samples was 9.58, making it impossible to know the shape of the experimental titration curve at higher $\mathrm{pH}$ values. To more accurately determine a distribution of phenolic $\mathrm{pK}_{\mathrm{a}}$ values, those higher $\mathrm{pH}$ values are needed. Perhaps future alkalinity titrations could be performed by first adding a known amount of base to increase the sample $\mathrm{pH}$ (and alkalinity) and thereby provide an experimental titration curve at the high end of the $\mathrm{pH}$ range, but this dataset lacked such data and therefore was insufficient to fully characterize the phenolic acid groups associated with dissolved organic matter. An additional titration curve with an initial sample $\mathrm{pH}$ of 10.78 was later tested with the optimized model parameters, and the agreement was good, but more titration curves with high $\mathrm{pH}$ are needed.

When fitting a site density, mean $\mathrm{pK}_{\mathrm{a}}$, and standard deviation about that $\mathrm{pK}_{\mathrm{a}}$ for the phenolic groups, it was found that the lack of high $\mathrm{pH}$ data in the titration curves meant that somewhat similar fits could be constructed using higher site densities along with a higher mean $\mathrm{pK}_{\mathrm{a}}$ and a wider distribution (larger standard deviation). In that way, just the lower tail of the $\mathrm{pK}_{\mathrm{a}}$ distribution was being used in the comparison of theoretical and experimental titration curves. Despite this problem, a best fit was found by using the mean $\mathrm{pK}_{\mathrm{a}}$ values from the initial 6-parameter optimization and following up with a 4-parameter optimization to find the best combination of site density and $\mathrm{pK}_{\mathrm{a}}$ standard deviation values that accompany those mean $\mathrm{pK}_{\mathrm{a}}$ inputs (table 4). The results indicated that the best-fit standard deviation values were quite small, around 0.05 units. This is somewhat counterintuitive, given what is known about the complex and variable structure of natural organic material and the accompanying range in acidities of its functional groups (Perdue and others, 1984; Bonn and Fish, 1991; Perdue and Ritchie, 2003). A more narrow distribution of acidities could be consistent with a single predominant source of dissolved organic matter to 
these samples. However, dissolved organic matter in the Klamath River system is likely to have multiple sources, such as wetlands, algae, or woody debris from historical and current mill operations. Further investigation into the sources of organic matter in the Klamath River system would help to better understand the variability of that material and its effect on $\mathrm{pH}$ buffering.

A second optimization was designed to test whether two monoprotic acids with no distribution of associated acidities could be used to fit the organic-matter portion of the experimental titration curves. After all, with the rather small $\mathrm{pK}_{\mathrm{a}}$ standard deviations found in the first optimization, the fitted Gaussian distribution of $\mathrm{pK}_{\mathrm{a}}$ values was almost identical to just two monoprotic acids. In this second optimization, only four organic-matter parameters were fitted using the theoretical titration curve: two site densities and two $\mathrm{pK}_{\mathrm{a}}$ values. The results were quite similar to and slightly better than the results from the first optimization, with a mean absolute volume error of about 10.1 counts per titration (800 counts to $1 \mathrm{~mL}$ of acid volume). The mean absolute volume error from the first optimization (6 parameters) was about 10.2 counts per titration.

Erring on the side of simplicity, it was decided to model the $\mathrm{pH}$ buffering of dissolved organic matter in the Klamath River using just two monoprotic acids and the parameters listed in table 4 for optimization \#2. Although this is a simple approach, the resulting theoretical titration curves do a remarkably good job of fitting the experimental titration curves. Three examples from the 24 fitted datasets are shown in figures $5 A, \underline{B}$, and $\underline{C}$, in which the measured titration curves (points) are compared against four different theoretical titration curves. The simplest theoretical titration curve accounts only for the chemistry of carbonic acid and water, in which hydroxide, carbonate, and bicarbonate are the only entities that can be titrated. Successive theoretical curves then add the effects of ammonia, phosphates, and dissolved organic matter. In most of the Klamath River samples having a high $\mathrm{pH}$, the carbonate-only theoretical titration curve failed to capture the shape of the measured titration curve, particularly for the higher-pH part of the curve. Adding in the effects of ammonia often helped when ammonia concentrations were high (close to or higher than $1.0 \mathrm{mg} / \mathrm{L}$ as nitrogen) and the sample $\mathrm{pH}$ was above 8.5. Phosphates rarely had a visible effect on the theoretical titration curve for the range of phosphate concentrations in these samples. Dissolved organic matter had a far more important and substantive effect on the theoretical titration curve for these samples and was instrumental in capturing the shape of the measured titration curve. Clearly, for these Klamath River samples, dissolved organic matter appears to be an important constituent that can buffer the $\mathrm{pH}$ of the river when algal blooms consume carbonic acid and force the $\mathrm{pH}$ to levels of 8 and above.
Table 4. Dissolved organic-matter acid dissociation constants and site densities for the Link River to Keno Dam reach of the Klamath River, Oregon, resulting from two best-fit optimizations of 24 measured alkalinity titration curves.

[Abbreviations: $\mathrm{pK}_{\mathrm{a}}$, acid dissociation constant; std. dev., standard deviations; - , not applicable]

\begin{tabular}{clcc}
\hline Acid group & Model parameter & $\begin{array}{c}\text { Optimization } \\
\text { number 1 } \\
\text { (2 acid } \\
\text { distributions) }\end{array}$ & $\begin{array}{c}\text { Optimization } \\
\text { number 2 } \\
\text { (2 monoprotic } \\
\text { acids) }\end{array}$ \\
\hline \multirow{2}{*}{$\begin{array}{c}\text { (Carboxylics) } \\
\text { Site density }\end{array}$} & 0.1751 & 0.1925 \\
& $\mathrm{pK}_{\mathrm{a}}$ mean & 5.502 & 5.584 \\
\hline \multirow{2}{*}{ pK } & Std. dev. & 0.047 & - \\
\hline (Phenolics) & $\mathrm{pK}_{\mathrm{a}}$ mean & 0.5828 & 0.6466 \\
& $\mathrm{pK}$ std. dev. & 0.738 & 9.594 \\
\hline & & & - \\
\hline
\end{tabular}

Although the nature of the dissolved organic matter is likely to change over the course of a season and as a function of its various sources, representing its buffering with a pair of monoprotic acids in the model calculations appears to be a good first step in capturing that process.

\section{Recalculation of Boundary Conditions for Total Inorganic Carbon}

With the inclusion of organic matter, orthophosphorus, and ammonia into the internal CE-QUAL-W2 calculations of $\mathrm{pH}$, it is also necessary to adjust the concentration of total inorganic carbon in the model input files. Prior to the enhanced buffering updates, the concentration of total inorganic carbon for the inflows into the model was calculated from field measurements of $\mathrm{pH}$, sample titrations to measure alkalinity, and an assumption that the alkalinity is predominantly due to bicarbonate, carbonate, and hydroxide. When that is the case, the alkalinity equation was simplified:

$$
\mathrm{Alk} \approx \mathrm{Alk}_{\mathrm{carb}}=\left[\mathrm{HCO}_{3}^{-}\right]+2\left[\mathrm{CO}_{3}^{2-}\right]+\left[\mathrm{OH}^{-}\right]-\left[\mathrm{H}^{+}\right]
$$

and the determination of the total inorganic carbon concentration was relatively straightforward once the values of the acid dissociation constants for carbonic acid are known:

$$
\mathrm{C}_{\mathrm{T}}=\frac{\left\{\mathrm{H}^{+}\right\}^{2}+\mathrm{K}_{1}^{\prime}\left\{\mathrm{H}^{+}\right\}+\mathrm{K}_{1}^{\prime} \mathrm{K}_{2}^{\prime}}{\mathrm{K}_{1}^{\prime}\left\{\mathrm{H}^{+}\right\}+2 \mathrm{~K}_{1}^{\prime} \mathrm{K}_{2}^{\prime}}\left(\text { Alk }-\frac{\mathrm{K}_{\mathrm{w}}^{\prime}}{\left\{\mathrm{H}^{+}\right\}}+\frac{\left\{\mathrm{H}^{+}\right\}}{\gamma_{\mathrm{H}^{+}}}\right)
$$



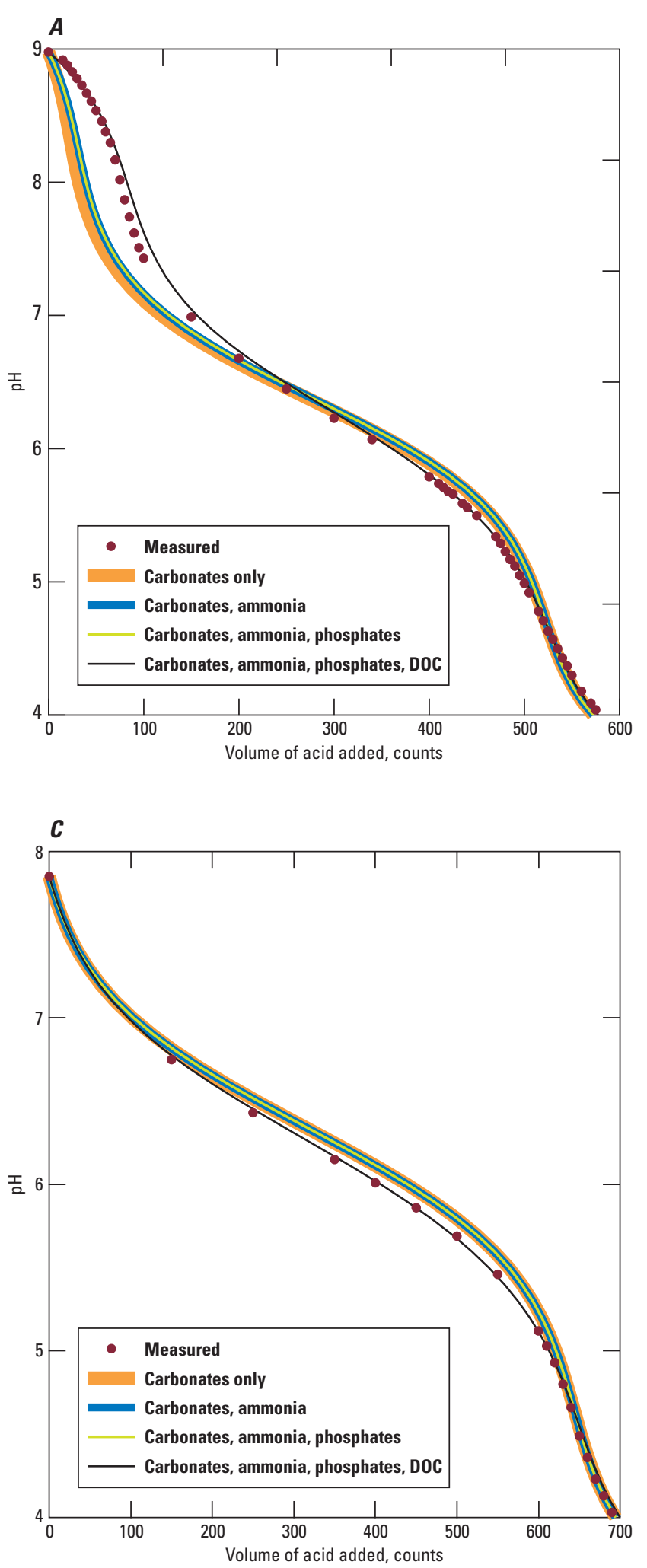

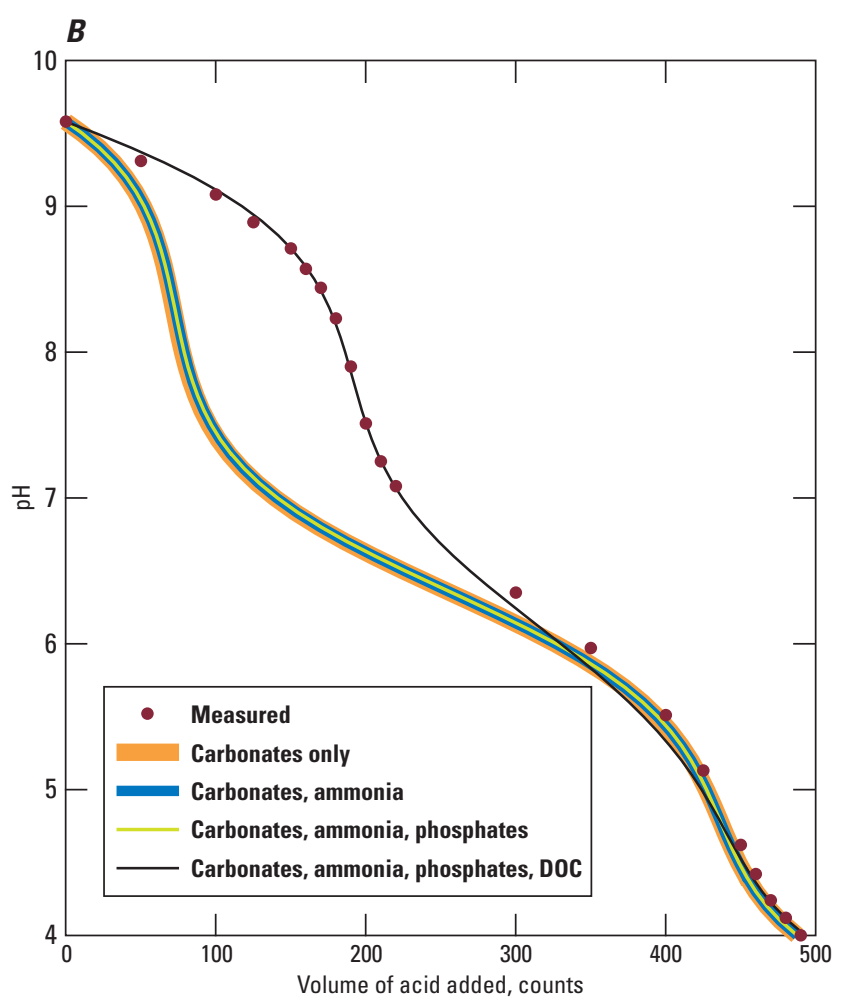

Figure 5. Example titration curves of four theoretical titration curves and measured data from the Link River to Keno Dam reach of the Klamath River, Oregon. DOC, dissolved organic carbon. (A) In this sample at Miller Island July 17, 2007, alkalinity was $52.8 \mathrm{mg} / \mathrm{L}$ as $\mathrm{CaCO}_{3}$, ammonia concentration was $1.1 \mathrm{mg} / \mathrm{L}$ as N, phosphate concentration was $0.171 \mathrm{mg} / \mathrm{L}$, and DOC concentration was $11.1 \mathrm{mg} / \mathrm{L}$. Ammonia had a visible effect on the theoretical titration curve, but organic matter was important in capturing the shape of the measured curve. $(B)$ In this sample at Link River August 14,2007 , alkalinity was $44.2 \mathrm{mg} / \mathrm{L}$ as $\mathrm{CaCO}_{3}$, ammonia concentration was $0.068 \mathrm{mg} / \mathrm{L}$ as $\mathrm{N}$, phosphate concentration was $0.104 \mathrm{mg} / \mathrm{L}$, and DOC concentration was $11.4 \mathrm{mg} / \mathrm{L}$. Ammonia had little effect on the shape of the curve because the ammonia concentration was low, but organic matter was important to the shape of the titration curve. $(C)$ In this sample at Keno August 14, 2007, alkalinity was $65.2 \mathrm{mg} / \mathrm{L}$ as $\mathrm{CaCO}_{3}$, ammonia concentration was $1.01 \mathrm{mg} / \mathrm{L}$ as $\mathrm{N}$, phosphate concentration was $0.165 \mathrm{mg} / \mathrm{L}$, and the DOC concentration was $12.5 \mathrm{mg} / \mathrm{L}$. Because the sample $\mathrm{pH}$ was less than 8.0 , ammonia and organic matter had little effect on the high end of the titration curve, but organic matter had a slight effect on the lower part of the curve. 
Activating the enhanced pH buffering routines in CE-QUAL-W2 means that, to the extent that such enhanced buffering is important compared to that provided by bicarbonate and carbonate, the boundary condition total inorganic carbon concentration must be computed by taking into account the contributions of $\mathrm{Alk}_{\mathrm{am}}$, $\mathrm{Alk}_{\mathrm{p}}$, and $\mathrm{Alk}_{\mathrm{OM}}$ if those are activated in the model. Taking all three into account, the equation for $\mathrm{C}_{\mathrm{T}}$ becomes:

$$
\begin{aligned}
\mathrm{C}_{\mathrm{T}}= & \frac{\left\{\mathrm{H}^{+}\right\}^{2}+\mathrm{K}_{1}^{\prime}\left\{\mathrm{H}^{+}\right\}+\mathrm{K}_{1}^{\prime} \mathrm{K}_{2}^{\prime}}{\mathrm{K}_{1}^{\prime}\left\{\mathrm{H}^{+}\right\}+2 \mathrm{~K}_{1}^{\prime} \mathrm{K}_{2}^{\prime}}\left(A l k-\frac{\mathrm{K}_{\mathrm{w}}^{\prime}}{\left\{\mathrm{H}^{+}\right\}}+\frac{\left\{\mathrm{H}^{+}\right\}}{\gamma_{\mathrm{H}^{+}}}-\mathrm{N}_{\mathrm{T}} \frac{\mathrm{K}_{\mathrm{am}}^{\prime}}{\left\{\mathrm{H}^{+}\right\}+\mathrm{K}_{\mathrm{am}}^{\prime}}\right. \\
& \left.-\mathrm{P}_{\mathrm{T}}\left(\frac{\mathrm{K}_{\mathrm{P} 1}^{\prime} \mathrm{K}_{\mathrm{P} 2}^{\prime}\left\{\mathrm{H}^{+}\right\}+2 \mathrm{~K}_{\mathrm{P} 1}^{\prime} \mathrm{K}_{\mathrm{P} 2}^{\prime} \mathrm{K}_{\mathrm{P} 3}^{\prime}-\left\{\mathrm{H}^{+}\right\}^{3}}{\left\{\mathrm{H}^{+}\right\}^{3}+\mathrm{K}_{\mathrm{P} 1}^{\prime}\left\{\mathrm{H}^{+}\right\}^{2}+\mathrm{K}_{\mathrm{P} 1}^{\prime} \mathrm{K}_{\mathrm{P} 2}^{\prime}\left\{\mathrm{H}^{+}\right\}+\mathrm{K}_{\mathrm{P} 1}^{\prime} \mathrm{K}_{\mathrm{P} 2}^{\prime} \mathrm{K}_{\mathrm{P} 3}^{\prime}}\right)-\mathrm{A}_{\mathrm{T}} \sum_{i=1}^{\mathrm{n}_{\mathrm{a}}} \delta_{i}\left(\frac{1}{1+10^{\left(\mathrm{pK}_{\mathrm{a} 1}^{\prime}-\mathrm{pH}\right)}}-\frac{1}{\left.1+10^{\left(\mathrm{pK}_{\mathrm{a}}^{\prime}\right.}-4.5\right)}\right)\right)
\end{aligned}
$$

If neglecting activity corrections in a freshwater system, a slightly simpler equation results:

$$
\begin{aligned}
\mathrm{C}_{\mathrm{T}}= & \frac{\left[\mathrm{H}^{+}\right]^{2}+\mathrm{K}_{1}\left[\mathrm{H}^{+}\right]+\mathrm{K}_{1} \mathrm{~K}_{2}}{\mathrm{~K}_{1}\left[\mathrm{H}^{+}\right]+2 \mathrm{~K}_{1} \mathrm{~K}_{2}}\left(\mathrm{Alk}-\frac{\mathrm{K}_{\mathrm{W}}}{\left[\mathrm{H}^{+}\right]}+\left[\mathrm{H}^{+}\right]-\mathrm{N}_{\mathrm{T}} \frac{\mathrm{K}_{\mathrm{am}}}{\left[\mathrm{H}^{+}\right]+\mathrm{K}_{\mathrm{am}}}\right. \\
& \left.-\mathrm{P}_{\mathrm{T}}\left(\frac{\mathrm{K}_{\mathrm{P} 1} \mathrm{~K}_{\mathrm{P} 2}\left[\mathrm{H}^{+}\right]+2 \mathrm{~K}_{\mathrm{P} 1} \mathrm{~K}_{\mathrm{P} 2} \mathrm{~K}_{\mathrm{P} 3}-\left[\mathrm{H}^{+}\right]^{3}}{\left[\mathrm{H}^{+}\right]^{3}+\mathrm{K}_{\mathrm{P} 1}\left[\mathrm{H}^{+}\right]^{2}+\mathrm{K}_{\mathrm{P} 1} \mathrm{~K}_{\mathrm{P} 2}\left[\mathrm{H}^{+}\right]+\mathrm{K}_{\mathrm{P} 1} \mathrm{~K}_{\mathrm{P} 2} \mathrm{~K}_{\mathrm{P} 3}}\right)-\mathrm{A}_{\mathrm{T}} \sum_{i=1}^{\mathrm{n}_{a}} \delta_{i}\left(\frac{1}{1+10^{\left(\mathrm{pK}_{\mathrm{ai}}-\mathrm{pH}\right)}}-\frac{1}{1+10^{\left(\mathrm{PK}_{\mathrm{d}_{1}}-4.5\right)}}\right)\right)
\end{aligned}
$$

where

$\mathrm{C}_{\mathrm{T}}$ is the total inorganic carbon concentration (in moles per liter; multiply result by 12,011

to obtain milligrams per liter),

$\mathrm{K}_{1}$ is the first acid dissociation constant for carbonic acid (table 3),

$\mathrm{K}_{2}$ is the second acid dissociation constant for carbonic acid (table 3),

$\mathrm{K}_{\mathrm{w}}$ is the acid dissociation constant for water (table 3),

$\mathrm{K}_{\mathrm{am}}$ is the acid dissociation constant for ammonium (table 3),

$\mathrm{K}_{\mathrm{P} 1}$ is the first acid dissociation constant for phosphoric acid (table 3),

$\mathrm{K}_{\mathrm{P} 2}$ is the second acid dissociation constant for phosphoric acid (table 3),

$\mathrm{K}_{\mathrm{P} 3}$ is the third acid dissociation constant for phosphoric acid (table 3),

Alk is the alkalinity in equivalents per liter [(Alk in milligrams per liter $\left.\mathrm{CaCO}_{3}\right) / 50,044$ ],

$\mathrm{N}_{\mathrm{T}}$ is the concentration of ammonia and ammonium in moles per liter [(ammonia+ammonium in $\mathrm{mg} / \mathrm{L}) / 14,006.74]$,

$\mathrm{P}_{\mathrm{T}}$ is the concentration of SRP in moles per liter [(SRP in milligrams per liter)/30,973.762],

$\mathrm{n}_{\mathrm{a}}$ is the number of monoprotic acid groups, or the number of distributions of those groups, used to represent organic matter,

$\mathrm{A}_{\mathrm{T}}$ is the total organic matter concentration in moles of carbon per liter. Depending on model options either [(DOC in milligrams per liter $) / 12,011]$ or $[(\mathrm{DOC}+\mathrm{POC}$ in milligrams per liter)/12,011],

$\delta_{i} \quad$ is the site density for acid group $i$, in moles of sites per mole of carbon,

$\mathrm{K}_{\mathrm{a}_{\mathrm{i}}}$ is the acid dissociation constant of the ith acid group for organic matter,

$\mathrm{pK}_{\mathrm{a}_{\mathrm{i}}}$ is the negative logarithm, base 10, of $\mathrm{K}_{\mathrm{a}_{\mathrm{i}}}$ (for distribution option (DIST), use 0.5, 1.0, 1.5, ..., 13.0, 13.5),

$\mathrm{pH}$ is the $\mathrm{pH}$ of the water, and

$\left[\mathrm{H}^{+}\right]$is the hydrogen ion concentration, defined as $10^{-\mathrm{pH}}$. 
For organic matter, if the user chooses to represent the organic acids with a distribution of $\mathrm{pK}$ values, the details of the final distribution of $\mathrm{pK}$ values is needed. The ph_buffering. opt model output file from a test run with the organic matter inputs provides the overall site densities for a range of $\mathrm{pK}$ values to use with organic matter. The site density is the moles of acid/base groups per mole of carbon. For the distribution (DIST) option, $27 \mathrm{pK}$ values from 0.5 to 13.5 , at 0.5 -unit increments, are used to characterize the final distribution and need to be accounted for in the calculation of $\mathrm{C}_{\mathrm{T}}$.

The calculation of total inorganic carbon concentrations from these equations can be used if the acid dissociation constants and site densities for organic matter have been determined, as in the upper Klamath River, or in different systems if the buffering provided by organic matter was smaller and could be ignored. It is best when simulating organic-matter buffering to analyze a series of alkalinity titration curves in advance of the modeling to estimate values for the organic matter site densities and $\mathrm{pK}_{\mathrm{a}}$ values. Otherwise, using these values as calibration parameters would require that the boundary conditions for $\mathrm{C}_{\mathrm{T}}$ be recomputed whenever the organic-matter parameter values that affect $\mathrm{pH}$ buffering are modified.

\section{Activity Corrections}

The PH_CO2 subroutine in CE-QUAL-W2 (appendix B) includes activity correction calculations for most of the inorganic constituents included in the computations. Most of that code was left unchanged in this version, with the exception that some additional constituents not included in the default implementation were given activity corrections. Ionic strength was estimated in the default code based on simulated values of total dissolved solids or salinity. A form of the extended Debye-Hückel equation was used in the default code to estimate activity coefficients for bicarbonate, carbonate, hydroxide, and the hydrogen ion $\left(\mathrm{H}^{+}\right)$. In this version, additional activity coefficients were computed for ammonia, ammonium, and the various phosphate species based on the existing equations and a set of ion size and charge factors tabulated for the Debye-Hückel equation by Stumm and Morgan (1996).

\section{Nonconservative Alkalinity}

Previous versions of CE-QUAL-W2 assumed that alkalinity is largely unaffected by chemical and biological reactions and responds only to changes in inputs, transport, and mixing. While alkalinity is largely a conservative quantity, it is not entirely conservative. Reactions such as ammonia nitrification and nitrate denitrification as well as photosynthesis and respiration can have small effects on alkalinity. A summary of these effects was provided by
Stumm and Morgan (1996) in their aquatic chemistry text (see table 4.5, page 173). The following reactions have effects on alkalinity:

- Utilization of ammonium during photosynthesis results in a decrease in alkalinity: 14 equivalents of alkalinity for every 16 moles of ammonium used. (Note: This stoichiometry was applied despite the fact that this equation is not balanced in $H$.)

$$
\begin{aligned}
& 106 \mathrm{CO}_{2}+16 \mathrm{NH}_{4}^{+}+\mathrm{HPO}_{4}^{2-}+108 \mathrm{H}_{2} \mathrm{O} \\
& \rightarrow \mathrm{C}_{106} \mathrm{H}_{263} \mathrm{O}_{110} \mathrm{~N}_{16} \mathrm{P}+107 \mathrm{O}_{2}+14 \mathrm{H}^{+}
\end{aligned}
$$

- Utilization of nitrate during photosynthesis results in an increase in alkalinity: 18 equivalents of alkalinity for every 16 moles of nitrate used.

$$
\begin{aligned}
& 106 \mathrm{CO}_{2}+16 \mathrm{NO}_{3}^{-}+\mathrm{HPO}_{4}^{2-}+122 \mathrm{H}_{2} \mathrm{O}+18 \mathrm{H}^{+} \\
& \rightarrow \mathrm{C}_{106} \mathrm{H}_{263} \mathrm{O}_{110} \mathrm{~N}_{16} \mathrm{P}+138 \mathrm{O}_{2}
\end{aligned}
$$

- Production of ammonium during respiration results in an increase in alkalinity: 14 equivalents of alkalinity for every 16 moles of ammonium produced. (Note: This stoichiometry was applied despite the fact that this equation is not balanced in $\mathrm{H}$.)

$$
\begin{aligned}
& \mathrm{C}_{106} \mathrm{H}_{263} \mathrm{O}_{110} \mathrm{~N}_{16} \mathrm{P}+107 \mathrm{O}_{2}+14 \mathrm{H}^{+} \\
& \rightarrow 106 \mathrm{CO}_{2}+16 \mathrm{NH}_{4}^{+}+\mathrm{HPO}_{4}^{2-}+108 \mathrm{H}_{2} \mathrm{O}
\end{aligned}
$$

- Nitrification of ammonium results in a decrease in alkalinity: 2 equivalents of alkalinity for every 1 mole of ammonium consumed.

$$
\mathrm{NH}_{4}^{+}+2 \mathrm{O}_{2} \rightarrow \mathrm{NO}_{3}^{-}+\mathrm{H}_{2} \mathrm{O}+2 \mathrm{H}^{+}
$$

- Denitrification of nitrate (to nitrogen gas) results in an increase in alkalinity: 1 equivalent of alkalinity per 1 mole of nitrate consumed.

$$
5 \mathrm{CH}_{2} \mathrm{O}+4 \mathrm{NO}_{3}^{-}+4 \mathrm{H}^{+} \rightarrow 5 \mathrm{CO}_{2}+2 \mathrm{~N}_{2}+7 \mathrm{H}_{2} \mathrm{O}
$$

As a result of changes made in this version of CE-QUAL-W2, the user is allowed to specify whether alkalinity is to be simulated as a conservative or a nonconservative quantity (see appendix B). 


\section{Summary of Updated Model Calibration}

After macrophytes and enhanced $\mathrm{pH}$ buffering were incorporated into the upper Klamath River model, the model was recalibrated by adjusting selected parameter values to obtain a good match between measured data and model output. Most parameters were unchanged from the original model calibration and remain as documented by Sullivan and others (2011). Those parameters that were adjusted are shown in table 5. The new macrophyte parameters, as used in the upper Klamath River model, are shown in table 2 and the enhanced buffering parameters are shown in table 6 .

During macrophyte calibration, the macrophyte field data were used to provide insight into the general patterns of density, spatial and temporal distributions of biomass, and macrophyte species characteristics. The model was not calibrated directly to the macrophyte field data because the macrophyte field data were collected in a different year (2011) than the model years (2006-09). Examples of the modeled distribution of the three macrophyte groups through the model domain on July 2 and August 17 for model year 2007 are shown in figure 6. Although most constituents in CE-QUAL-W2 are laterally averaged across the channel, macrophytes are modeled in a quasi three-dimensional mode so that macrophytes can be modeled at different depths from bank to bank across a model segment (Berger, 2000; Berger and Wells, 2008; Cole and Wells, 2008). As in the field data, the modeled pondweed density was highest in early summer and diminished by August, whereas coontail and common waterweed were simulated with a higher density in late summer and were more common in the downstream reaches near Keno Dam.

Macrophytes affect the cycles of oxygen, nutrients, organic matter, and $\mathrm{pH}$. In the updated model, the total annual production of dissolved oxygen by macrophytes is approximately the same order of magnitude as that by algae (fig. 7). Oxygen consumption by respiration is higher in macrophytes compared to algae, due in part to the fact that the macrophyte oxygen respiration parameter was adjusted to account for the large population of snails within the macrophytes. Dissolved oxygen production and consumption by macrophytes begins earlier in the year than oxygen production and consumption by algae, largely because the pondweed macrophytes are early season species, whereas the largest algal blooms occur in late June and early July.

Table 5. Parameter values changed as a result of calibration updates to the water-quality model for the Link River to Keno Dam reach of the Klamath River, Oregon.

[Abbreviations: ${ }^{\circ} \mathrm{C}$, degrees Celsius; g, gram; 1/day, per day]

\begin{tabular}{lccl}
\hline \multicolumn{1}{c}{ Parameter } & Original value & Updated value & \multicolumn{1}{c}{ Description } \\
\hline AG, blue-green & 3.09 & 2.3 & Maximum algal growth rate for blue-green algae, $1 /$ day \\
AT1, blue-green & 12 & 13 & Lower temperature parameter for rising rate function for blue-green algae, ${ }^{\circ} \mathrm{C}$ \\
AT3, blue-green & 35 & 30 & Lower temperature parameter for falling rate function for blue-green algae, ${ }^{\circ} \mathrm{C}$ \\
$\mathrm{CO} 2 \mathrm{R}$ & 1.2 & 0.1 & Sediment carbon dioxide release rate, fraction of sediment oxygen demand \\
\hline
\end{tabular}

Table 6. Enhanced pH buffering input parameters in the water-quality model for the Link River to Keno Dam reach of the Klamath River, Oregon.

[Abbreviations: $\mathrm{pK}_{\mathrm{a}}$, acid dissociation constant; OM, organic matter; POM, particulate matter]

\begin{tabular}{lcl}
\hline \multicolumn{1}{c}{ Parameter } & Value & \multicolumn{1}{c}{ Description } \\
\hline PHBUFC & ON & Option to use enhanced buffering routines \\
NCALKC & ON & Option to use nonconservative alkalinity algorithms \\
NH4BUFC & ON & Specifies whether ammonia/ammonium is included in pH buffering \\
PO4BUFC & ON & Specifies whether phosphoric acid is included in pH buffering \\
OMBUFC & ON & Specifies whether organic matter is included in pH buffering \\
OMTYPE & MONO & MONO specifies discrete pK values \\
NAG & 2 & Number of organic acid/base groups to model \\
POMBUFC & OFF & Specifies whether POM is included in OM buffering \\
SDEN1 & 0.1925 & Site density for organic group 1, in moles of acid/base sites per mole of carbon in OM \\
SDEN2 & 0.6466 & Site density for organic group 2, in moles of acid/base sites per mole of carbon in OM \\
PK1 & 5.584 & The $\mathrm{pK}_{\mathrm{a}}$ values (negative log10 of the acid dissociation constant) \\
PK2 & 9.594 & The $\mathrm{pK}_{\mathrm{a}}$ values (negative log10 of the acid dissociation constant) \\
\hline
\end{tabular}



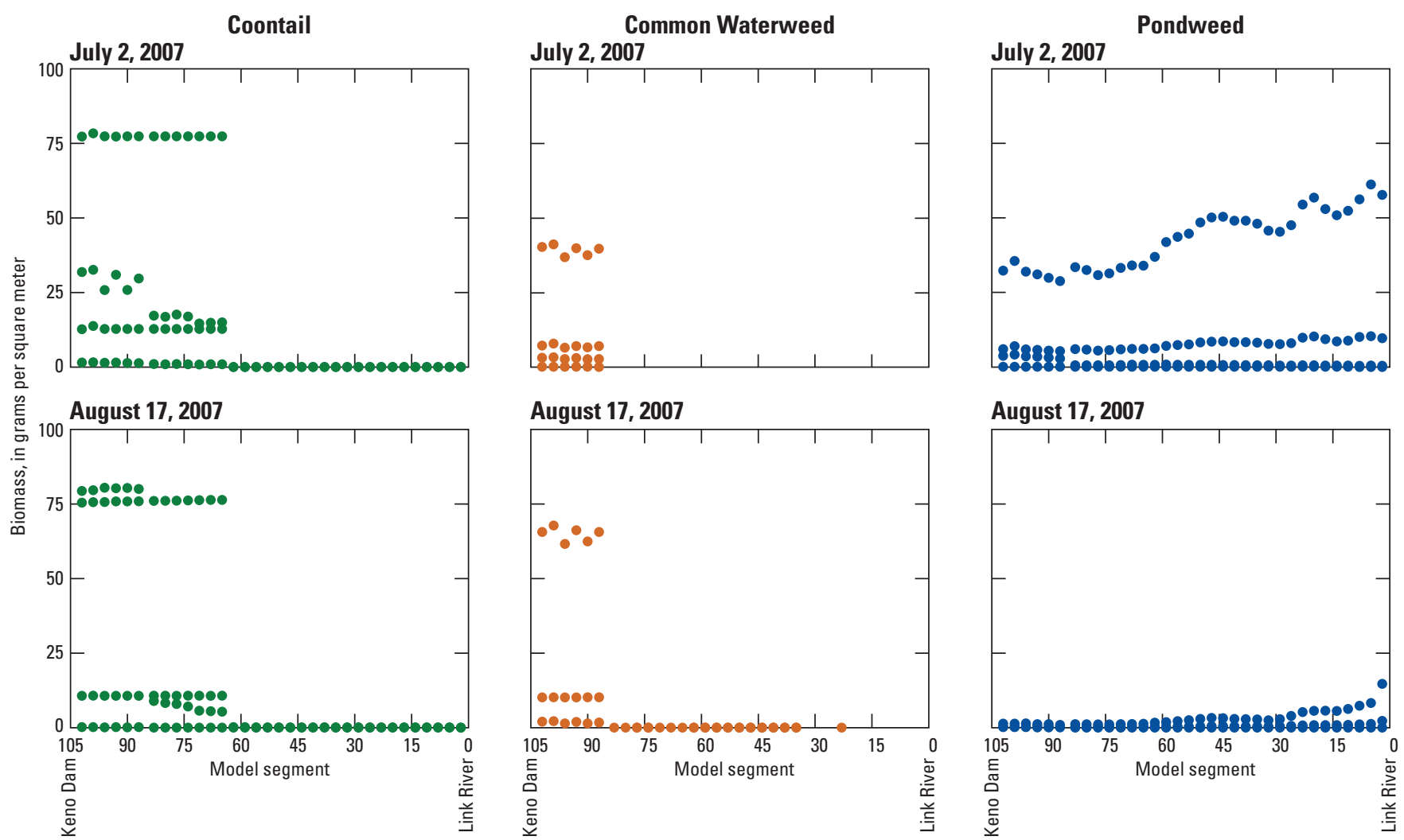

August 17, 2007
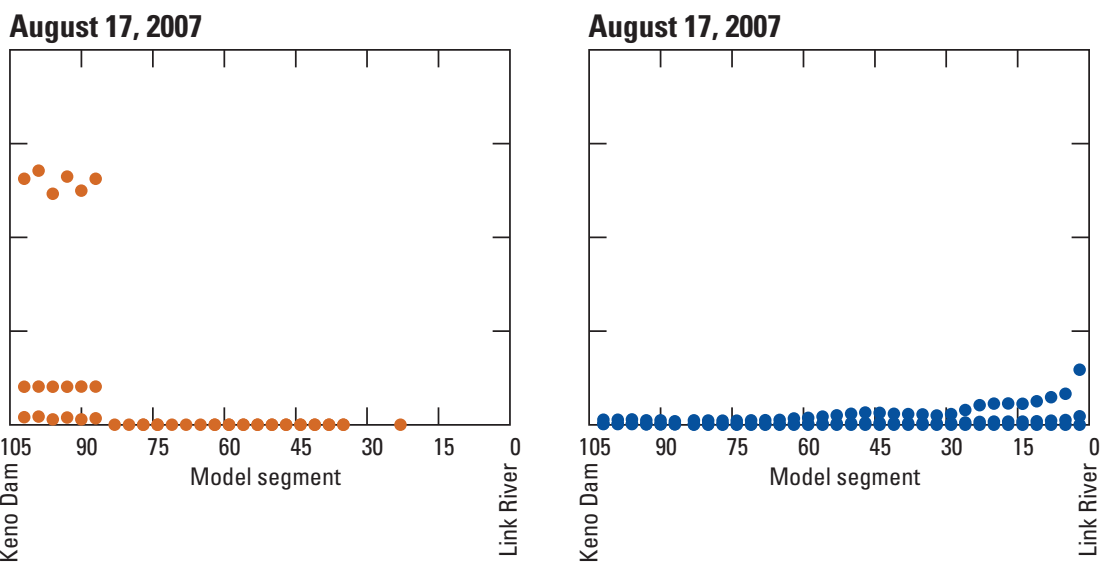

Figure 6. Modeled macrophyte biomass along the Link River to Keno Dam reach of the Klamath River, Oregon, on two selected dates. CE-QUAL-W2 provides macrophyte output at different depths across each segment cross section.
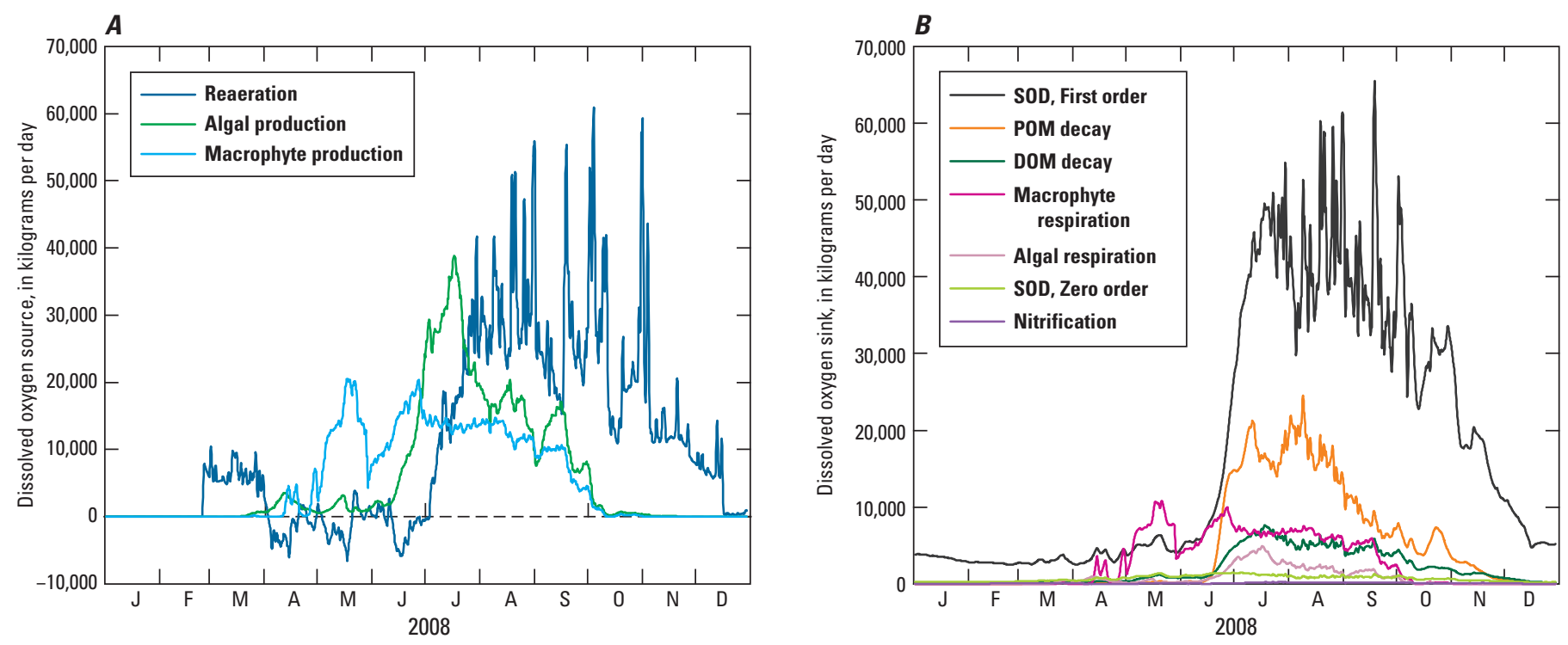

Figure 7. Modeled daily average dissolved-oxygen production $(A)$ sources and consumption $(B)$ sinks in the Link River to Keno Dam reach of the Klamath River, Oregon, in 2008. DOM, dissolved organic matter; POM, particulate organic matter; SOD, sediment oxygen demand. 
pH buffering by ammonia, phosphates, and dissolved organic matter was enabled in the recalibrated model, but buffering by particulate organic matter was disabled (table 6 ). Particulate organic matter, much of it derived from dying algae, may have some acid/base properties, but being enclosed in particles likely inhibits its reactivity with the bulk river water. Algae and macrophyte material may also have acid/ base properties, such as cell walls with carboxyl groups (Chojnacka, 2010), but this buffering was also assumed to be small relative to buffering by dissolved organic matter. Nonconservative alkalinity was turned on, and two monoprotic acids were used to simulate the dissolved organic matter buffering - one to represent carboxylic acids and one to represent phenolic and amine groups together.

The enhanced $\mathrm{pH}$ buffering algorithms had a notable effect on modeling $\mathrm{pH}$ in summer and fall. Without the enhanced buffering, the modeled $\mathrm{pH}$ was generally lower and subject to larger daily variability compared to measured $\mathrm{pH}$ (fig. 8). The addition of macrophytes also improved $\mathrm{pH}$ modeling, especially in the lower part of the reach near Keno Dam where macrophytes were more abundant (fig. 9). With both macrophytes and enhanced $\mathrm{pH}$ buffering implemented, the model was able to simulate $\mathrm{pH}$ well with mean absolute errors (MAE) of $\leq 0.34$ for years 2006-09 (fig. 10; table 7). The inclusion and calibration of $\mathrm{pH}$ in the upper Klamath River model will now allow model scenarios to examine the effect of management and other system changes on $\mathrm{pH}$, which is a water-quality limited constituent in this reach.

The updates to the model affected the error statistics of other constituents modestly. The most improved error statistics were for dissolved oxygen, with an average
MAE improvement of $0.1 \mathrm{mg} / \mathrm{L}$, and particulate carbon, with an average MAE improvement of $0.2 \mathrm{mg} / \mathrm{L}$. Average error statistics for other constituents were essentially the same compared to the original USGS model (Sullivan and others 2011). In addition to the model performance metrics included in table 7, measured and modeled $\mathrm{pH}$ and dissolved oxygen time series are shown in figures $10 \mathrm{~A}-\mathrm{D}$ and $\underline{11 A-D}$, respectively, for calendar years 2006-09. Algae, nutrients, organic matter, and bottom sediment are shown in figures $12 A-D$ for the calendar years 2006-09. Modeled temperature and specific conductance are not shown here; those plots are available in the original USGS Klamath River model report (Sullivan and others, 2011).

When interpreting measured/model comparison plots and error statistics, remember that model output and measured data are at the same time and location but not at the exact same scale. For example, measurements from a continuous monitor probe represent a small volume near the probe tip. Model output is from an entire model cell that might have dimensions of $1,000 \mathrm{ft} \times 500 \mathrm{ft} \times 2 \mathrm{ft}$ near-surface. Measured data and model output should show the same large-scale temporal and spatial patterns, but some mismatch at smaller scales can be expected as a result of these different scales.

The USGS upper Klamath River model has already been used to analyze water-quality effects of system changes in several preliminary model scenarios (Sullivan and others, 2011, 2012). The predictive improvements provided by the updated model will benefit future analyses of water-quality scenarios and help improve the understanding of water-quality processes in this reach of the Klamath River. 

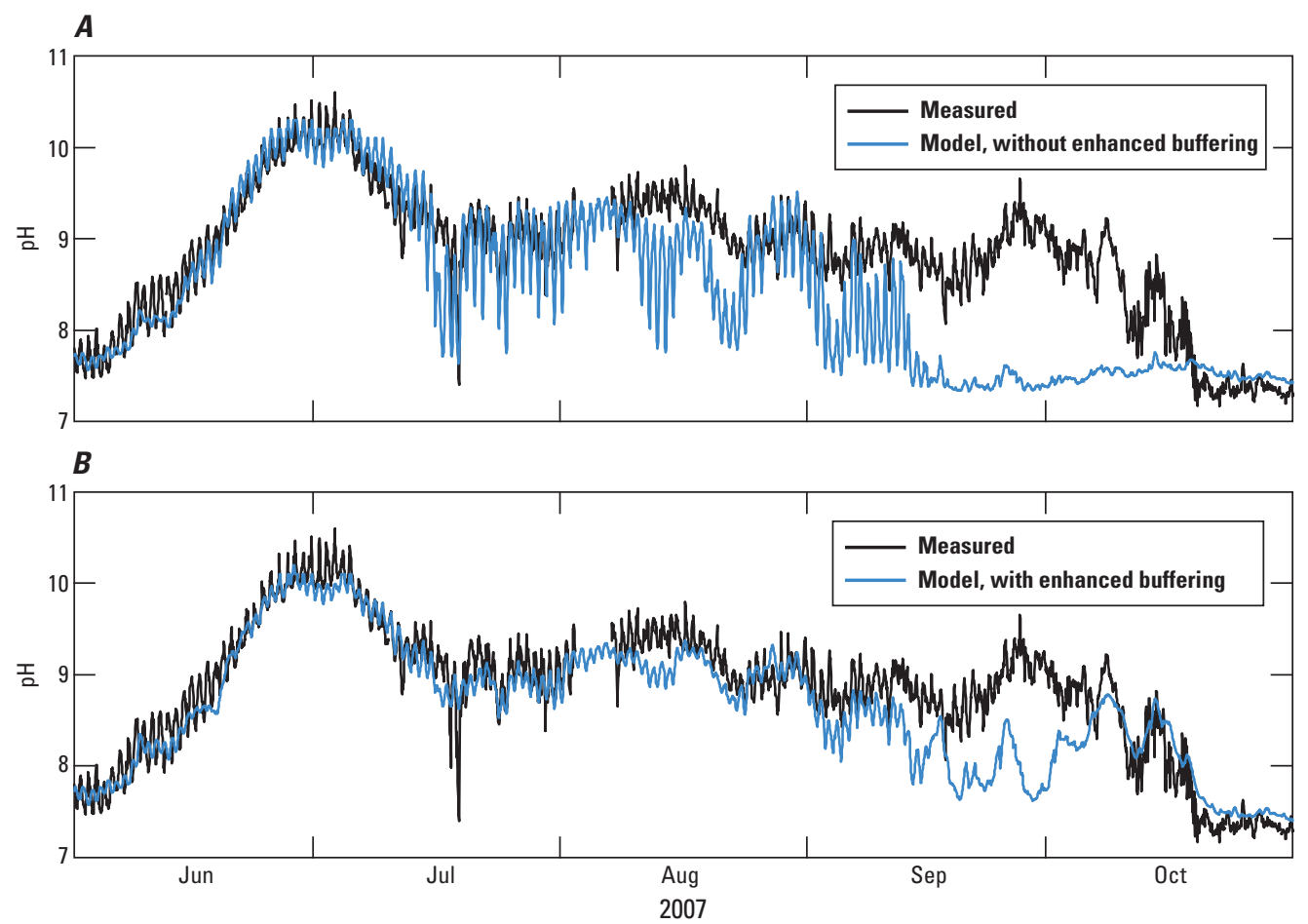

Figure 8. Modeled and measured $\mathrm{pH}$ at the Klamath River, Oregon, Railroad Bridge site in summer and fall 2007, $(A)$ without and $(B)$ with the new enhanced CE-QUAL-W2 $\mathrm{pH}$ buffering. To illustrate just the effect of the enhanced $\mathrm{pH}$ buffering, neither of the model runs shown includes macrophytes.
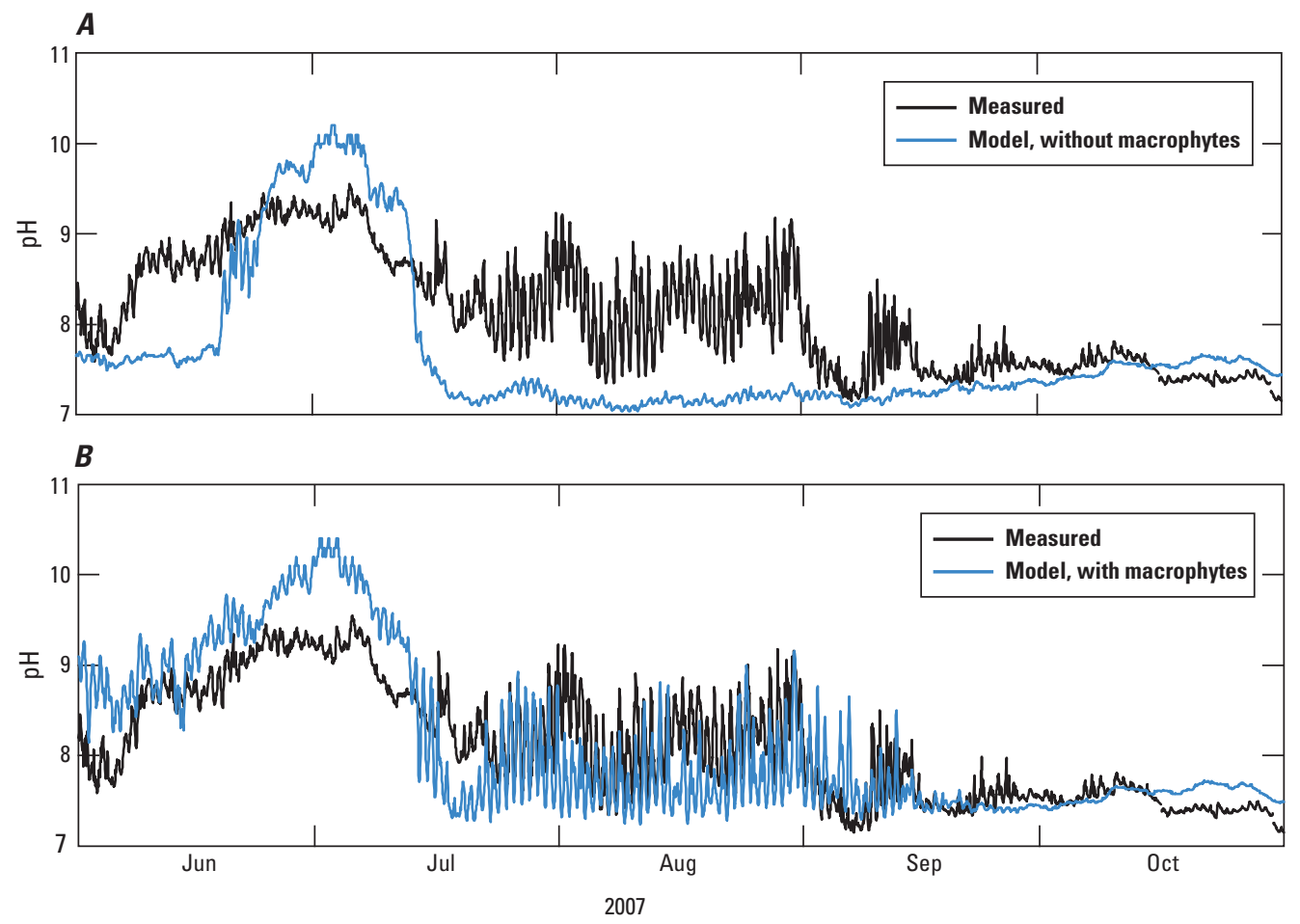

Figure 9. Modeled and measured pH at the Klamath River, Oregon, Keno site in summer and fall 2007, $(A)$ without macrophytes and $(B)$ with macrophytes. To illustrate just the effect of macrophytes, neither of the model runs shown includes enhanced $\mathrm{pH}$ buffering. 
Table 7. Goodness-of-fit statistics averaged over all calibration sites for the updated model of the Link River to Keno Dam reach of the Klamath River, Oregon.

[Abbreviations: ${ }^{\circ} \mathrm{C}$. degrees Celsius; <, less than; $\mu \mathrm{m}^{3} / \mathrm{mL}$, cubic micrometers per milliliter; $\mathrm{mg} / \mathrm{L}$, milligrams per liter; $\mathrm{rl}$, reporting level; $\times$, times]

\begin{tabular}{|c|c|c|c|c|c|c|c|}
\hline Constituent & Unit & Data type & $\begin{array}{c}\text { Range of } \\
\text { measured } \\
\text { values }\end{array}$ & Year & $\begin{array}{l}\text { Mean } \\
\text { error }\end{array}$ & $\begin{array}{l}\text { Mean } \\
\text { absolute } \\
\text { error }\end{array}$ & $\begin{array}{l}\text { Root mean } \\
\text { square error }\end{array}$ \\
\hline \multirow{4}{*}{ Water temperature } & \multirow{4}{*}{${ }^{\circ} \mathrm{C}$} & \multirow{4}{*}{ hourly } & \multirow{4}{*}{$0-28$} & 2006 & -0.03 & 0.55 & 0.70 \\
\hline & & & & 2007 & 0.06 & 0.63 & 0.78 \\
\hline & & & & 2008 & 0.17 & 0.63 & 0.80 \\
\hline & & & & 2009 & -0.17 & 0.58 & 0.72 \\
\hline \multirow{4}{*}{ Dissolved oxygen } & \multirow{4}{*}{$\mathrm{mg} / \mathrm{L}$} & \multirow{4}{*}{ hourly } & \multirow{4}{*}{$0-20$} & 2006 & -0.02 & 0.98 & 1.37 \\
\hline & & & & 2007 & 0.70 & 1.23 & 1.70 \\
\hline & & & & 2008 & -0.18 & 0.95 & 1.36 \\
\hline & & & & 2009 & -0.65 & 1.27 & 1.71 \\
\hline \multirow{4}{*}{$\mathrm{pH}$} & & \multirow{4}{*}{ hourly } & \multirow{4}{*}{$7-11$} & 2006 & -0.14 & 0.26 & 0.36 \\
\hline & & & & 2007 & -0.04 & 0.30 & 0.39 \\
\hline & & & & 2008 & -0.02 & 0.25 & 0.33 \\
\hline & & & & 2009 & -0.20 & 0.34 & 0.46 \\
\hline \multirow{2}{*}{ Ammonia } & \multirow{2}{*}{$\mathrm{mg} / \mathrm{L}$} & \multirow{2}{*}{ grab } & \multirow{2}{*}{$<\mathrm{rl}-1.7$} & 2007 & 0.00 & 0.12 & 0.16 \\
\hline & & & & 2008 & -0.11 & 0.22 & 0.28 \\
\hline \multirow{2}{*}{ Nitrate } & \multirow{2}{*}{$\mathrm{mg} / \mathrm{L}$} & \multirow{2}{*}{ grab } & \multirow{2}{*}{$<\mathrm{rl}-0.8$} & 2007 & 0.01 & 0.03 & 0.03 \\
\hline & & & & 2008 & 0.01 & 0.03 & 0.03 \\
\hline \multirow{2}{*}{ Particulate nitrogen } & \multirow{2}{*}{$\mathrm{mg} / \mathrm{L}$} & \multirow{2}{*}{ grab } & \multirow{2}{*}{$0.06-4.0$} & 2007 & -0.21 & 0.29 & 0.49 \\
\hline & & & & 2008 & -0.17 & 0.25 & 0.39 \\
\hline \multirow{2}{*}{ Total nitrogen } & \multirow{2}{*}{$\mathrm{mg} / \mathrm{L}$} & \multirow{2}{*}{ grab } & \multirow{2}{*}{$0.6-5.9$} & 2007 & 0.03 & 0.40 & 0.59 \\
\hline & & & & 2008 & -0.08 & 0.42 & 0.52 \\
\hline \multirow{2}{*}{ Orthophosphorus } & \multirow{2}{*}{$\mathrm{mg} / \mathrm{L}$} & \multirow{2}{*}{ grab } & $0.01-0.27$ & 2007 & 0.01 & 0.03 & 0.04 \\
\hline & & & $0.01-0.21$ & 2008 & 0.00 & 0.02 & 0.03 \\
\hline Total phosphorus & $\mathrm{mg} / \mathrm{L}$ & grab & $0.06-0.50$ & 2007 & 0.01 & 0.05 & 0.07 \\
\hline rotal piruspiturus & (111) & giau & $0.00-0.50$ & 2008 & 0.00 & 0.04 & 0.05 \\
\hline Blue-green algae & $\mathrm{um}^{3} / \mathrm{mL}$ & grab & $0-113 \times 10^{6}$ & 2007 & $-4.7 \times 10^{6}$ & $7.6 \times 10^{6}$ & $14.9 \times 10^{6}$ \\
\hline Diue-green aigae & HIII/IIIL & gidD & $0-113 \times 10$ & 2008 & $-2.2 \times 10^{6}$ & $3.4 \times 10^{6}$ & $5.8 \times 10^{6}$ \\
\hline Particulate carbon & $\mathrm{mg} / \mathrm{L}$ & grab & $0.5-18$ & 2007 & 0.07 & 1.09 & 1.72 \\
\hline 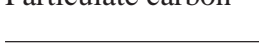 & IIIS L & giau & $0.0-10$ & 2008 & 0.41 & 1.31 & 1.89 \\
\hline Dissolved organic & & & & 2007 & 0.37 & 0.72 & 1.12 \\
\hline carbon & mg/L & grab & $5-14$ & 2008 & -0.39 & 0.71 & 0.88 \\
\hline
\end{tabular}


A. 2006

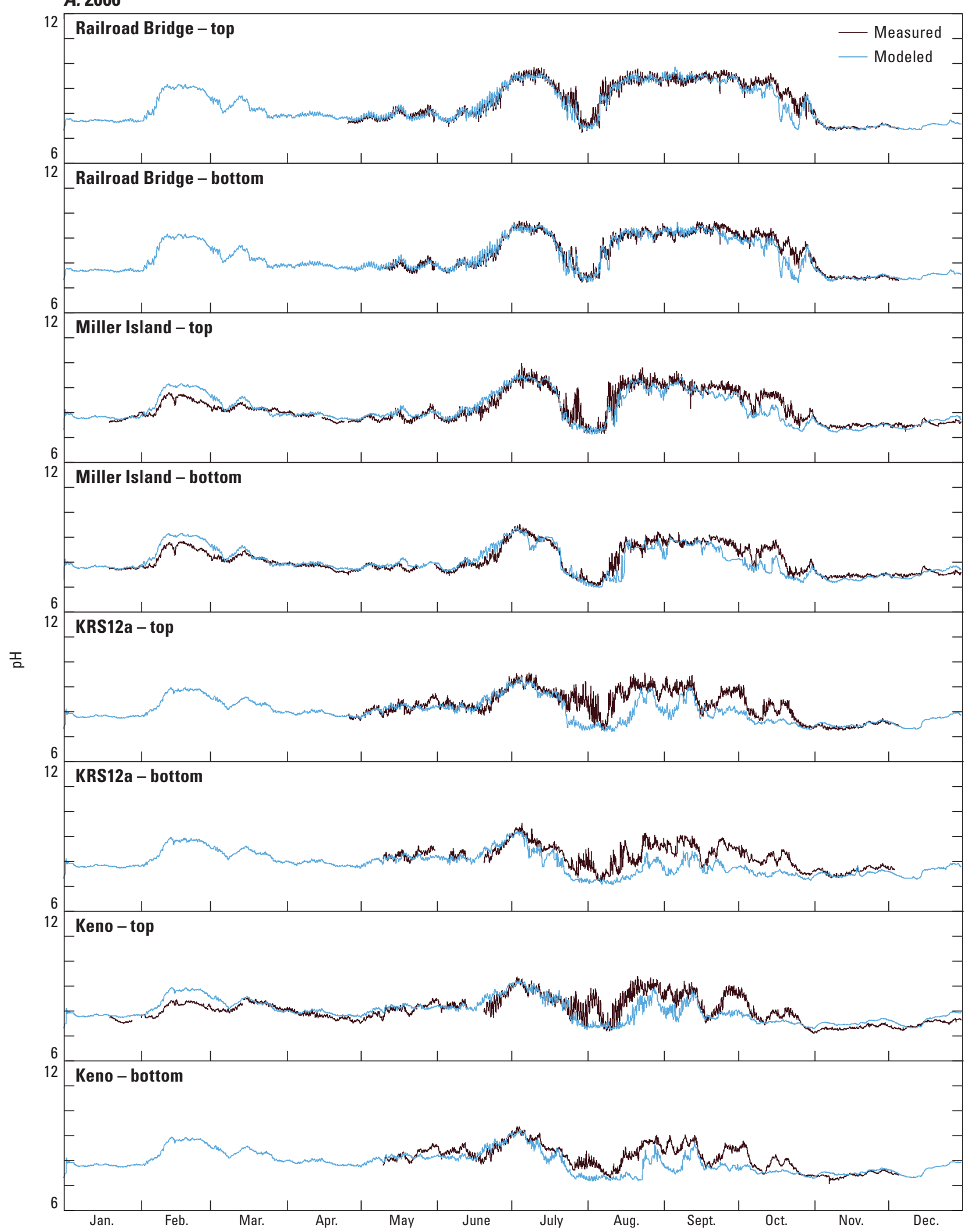

Figure 10. Measured and modeled hourly pH during calendar years $(A)$ 2006, $(B)$ 2007, $(C)$ 2008, and $(D) 2009$ for sites in the Link River to Keno Dam reach of the Klamath River, Oregon. Top results were from 1 meter below the river surface; bottom results were from 1 meter above the channel bottom. 


\section{B. 2007}

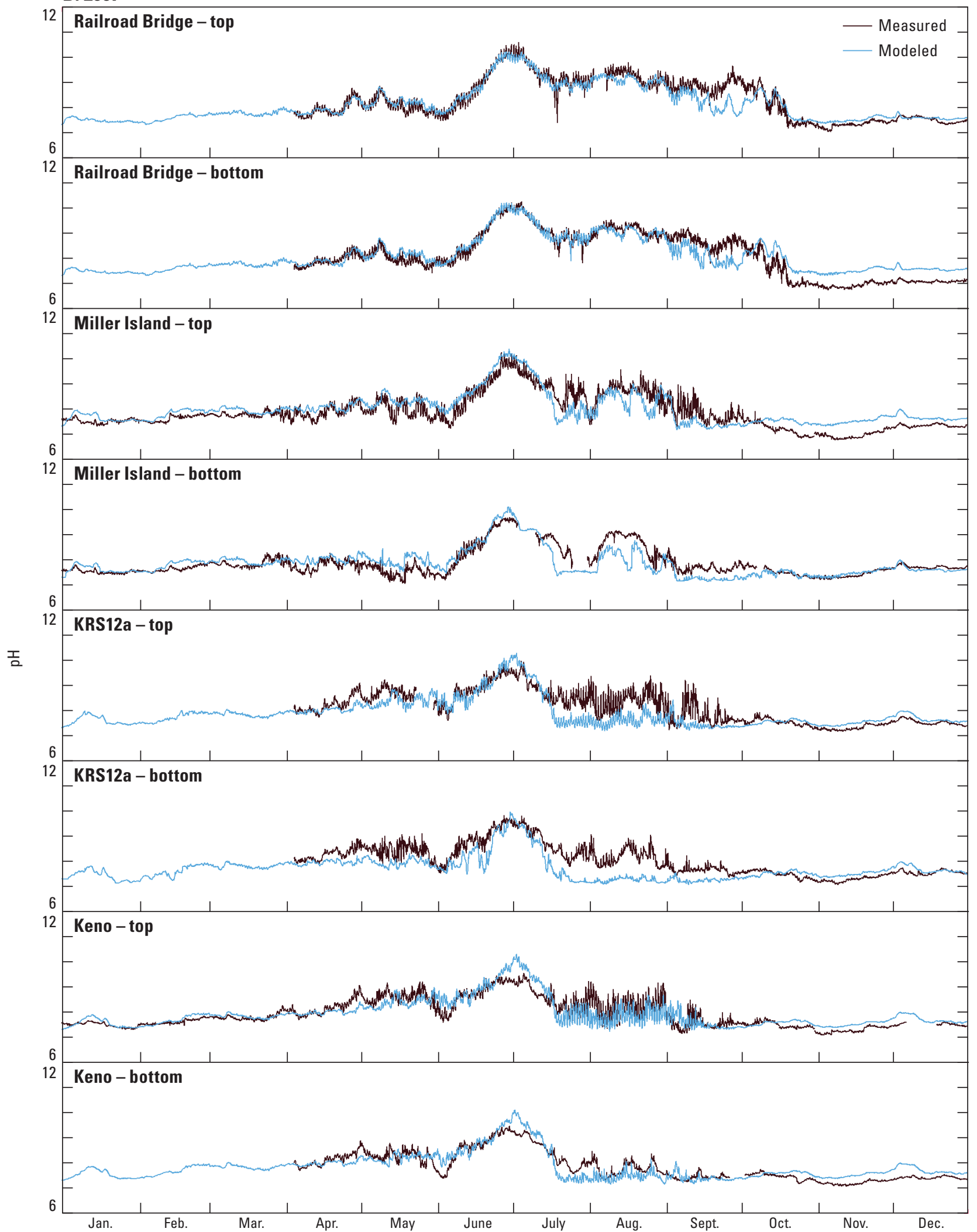

Figure 10.-Continued 


\section{2008}

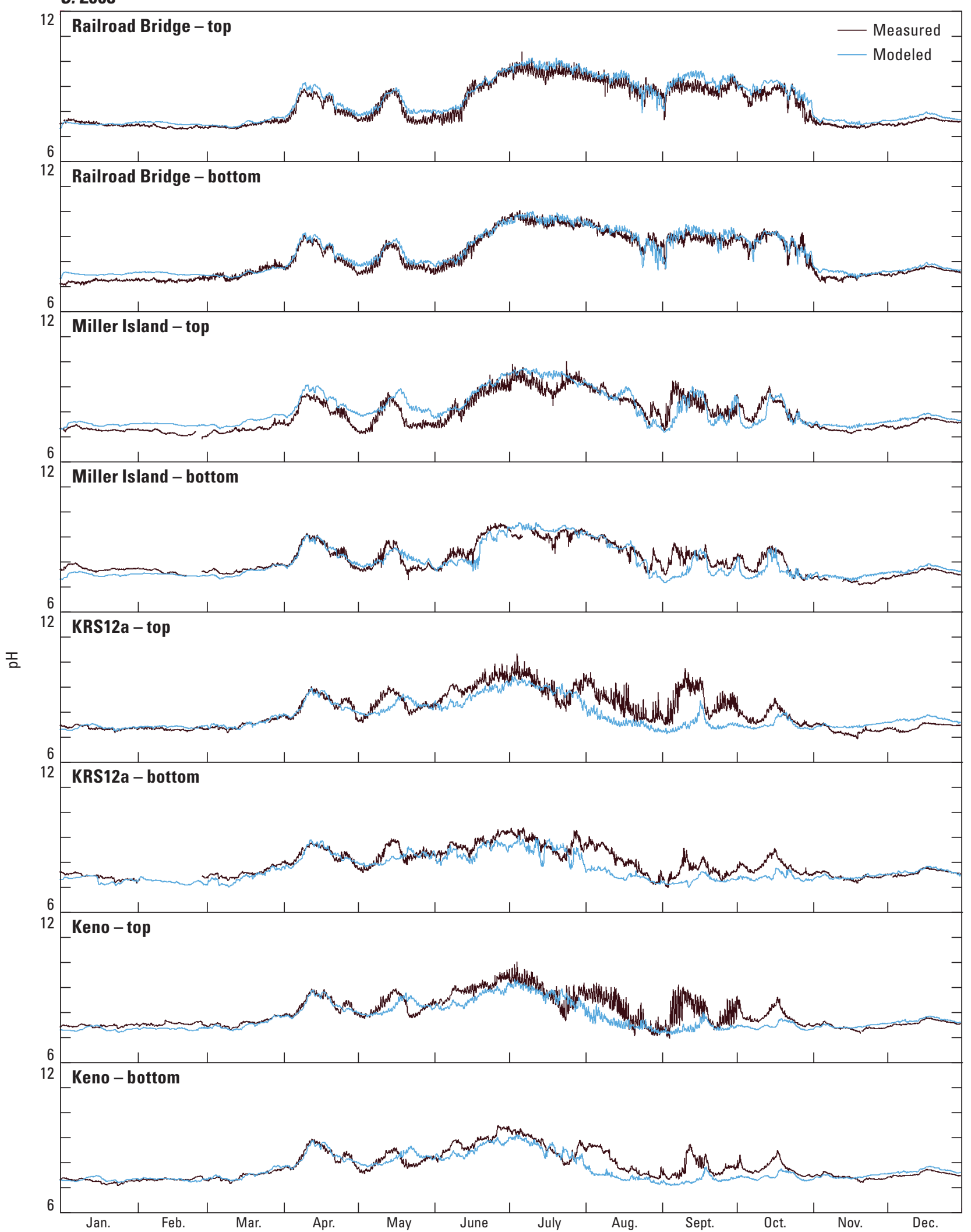

Figure 10.-Continued 


\section{2009}

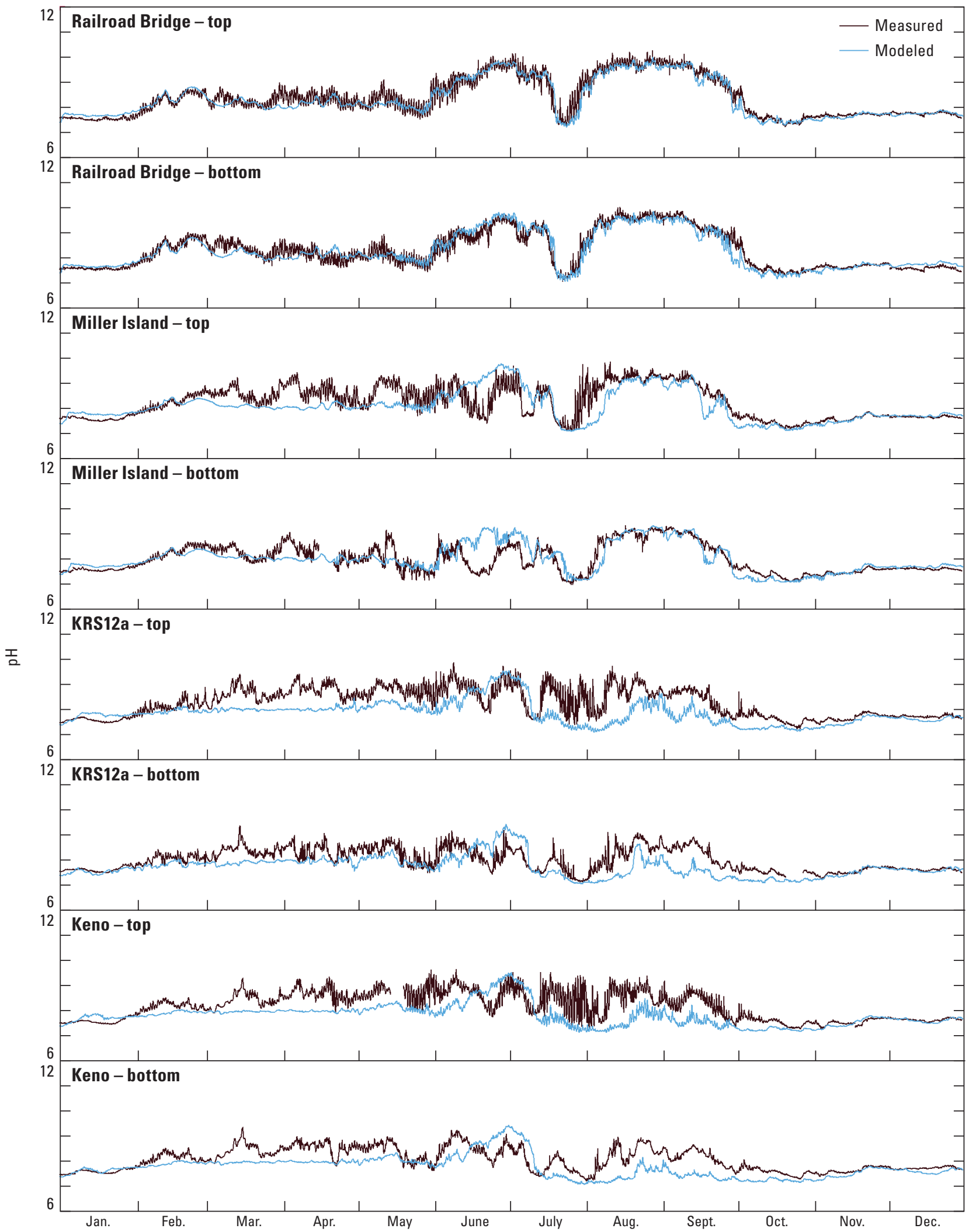

Figure 10.-Continued 
A. 2006

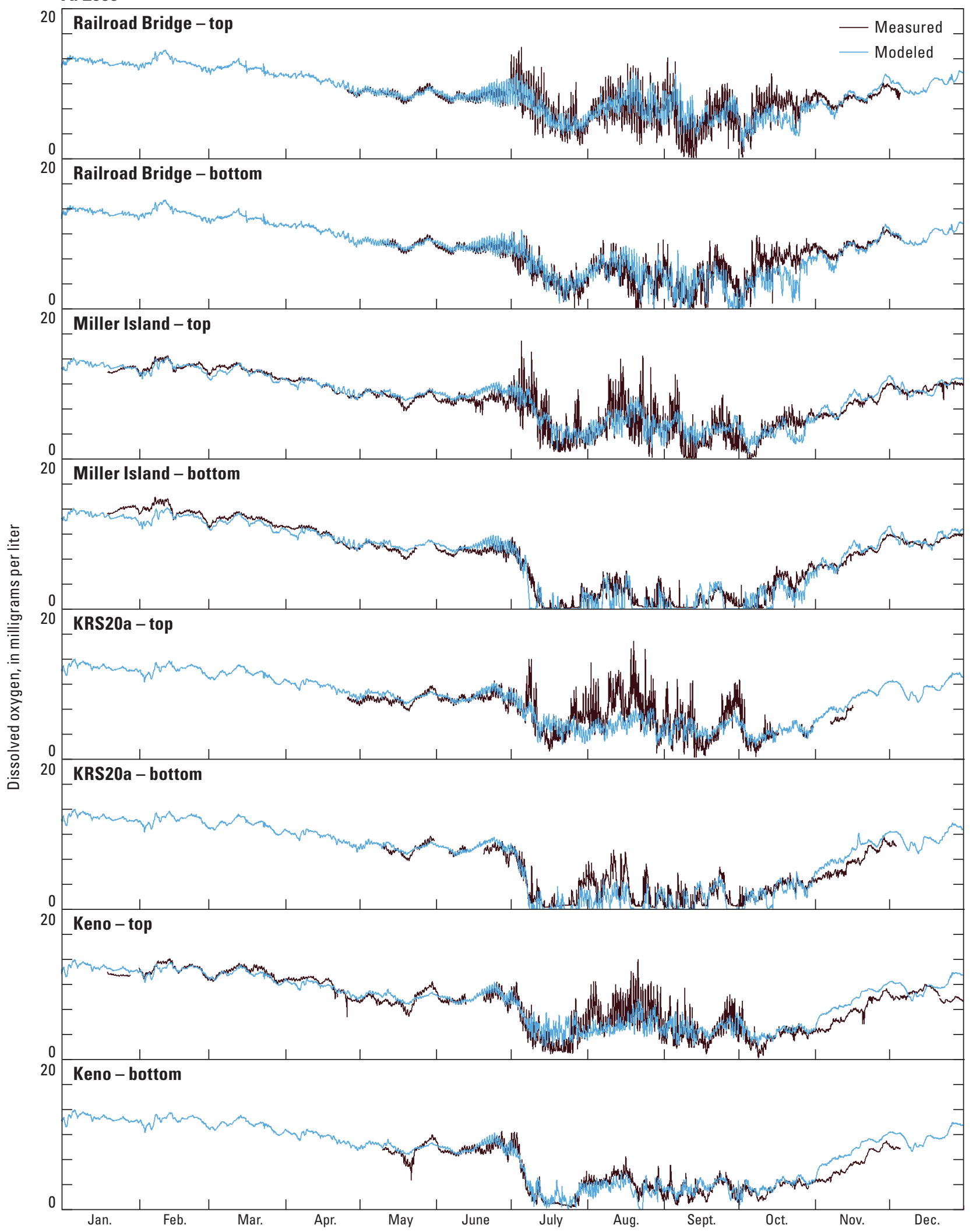

Figure 11. Measured and modeled hourly dissolved-oxygen concentrations during calendar years $(A) 2006,(B)$ 2007, (C) 2008, and (D) 2009 for sites in the Link River to Keno Dam reach of the Klamath River, Oregon. Top results were from 1 meter below the river surface; bottom results were from 1 meter above the channel bottom. 


\section{B. 2007}

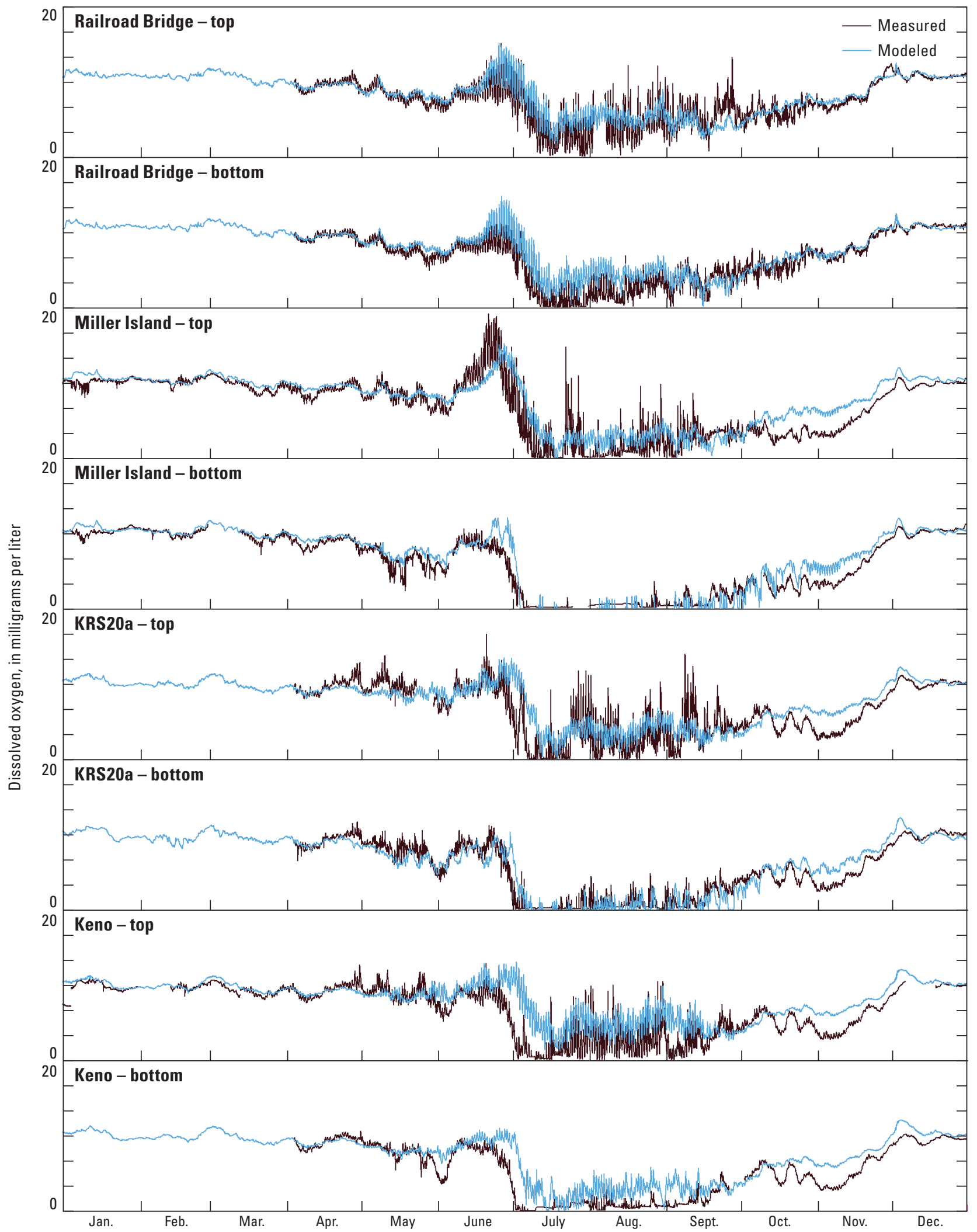

Figure 11.-Continued 


\section{2008}

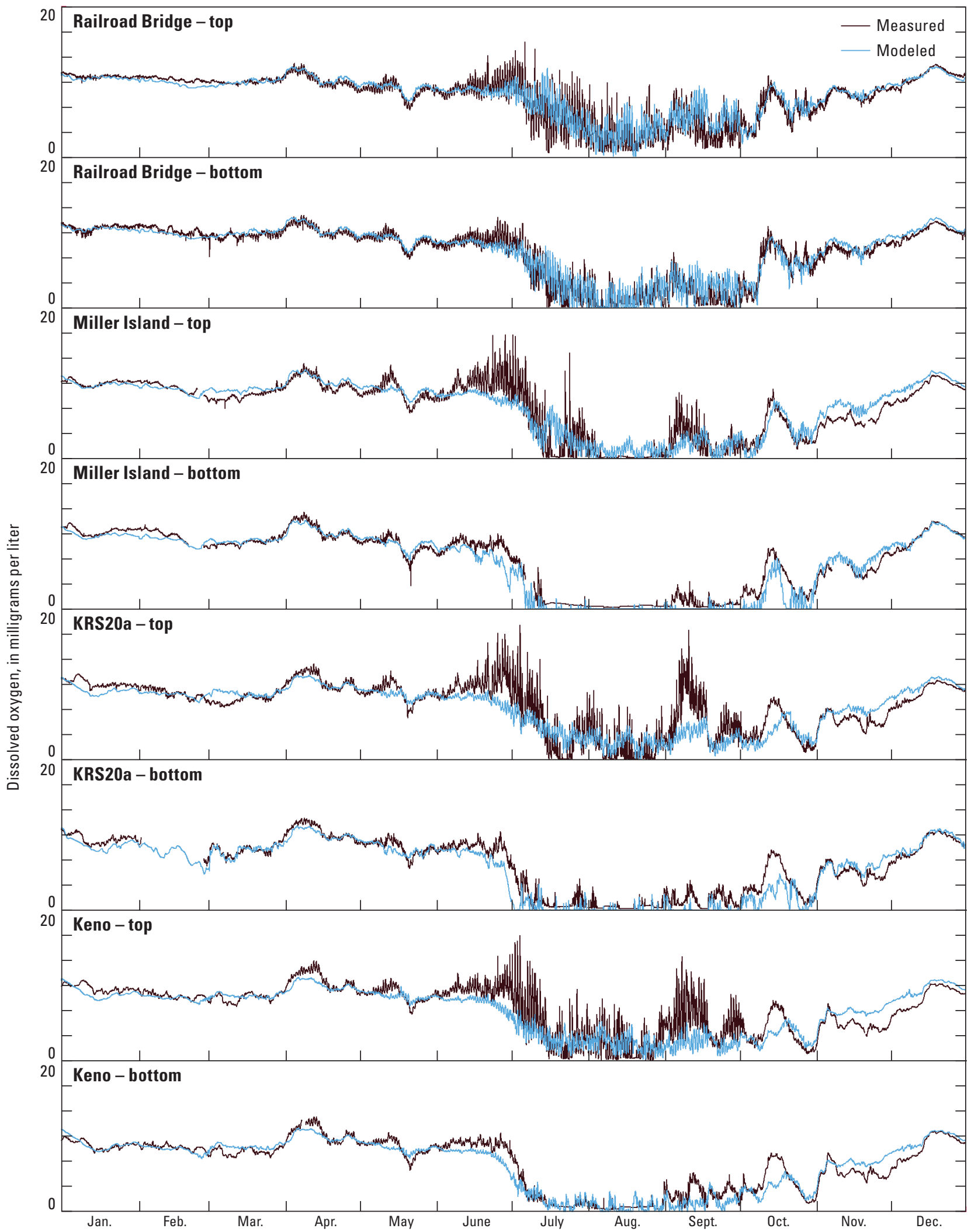

Figure 11.-Continued 
D. 2009

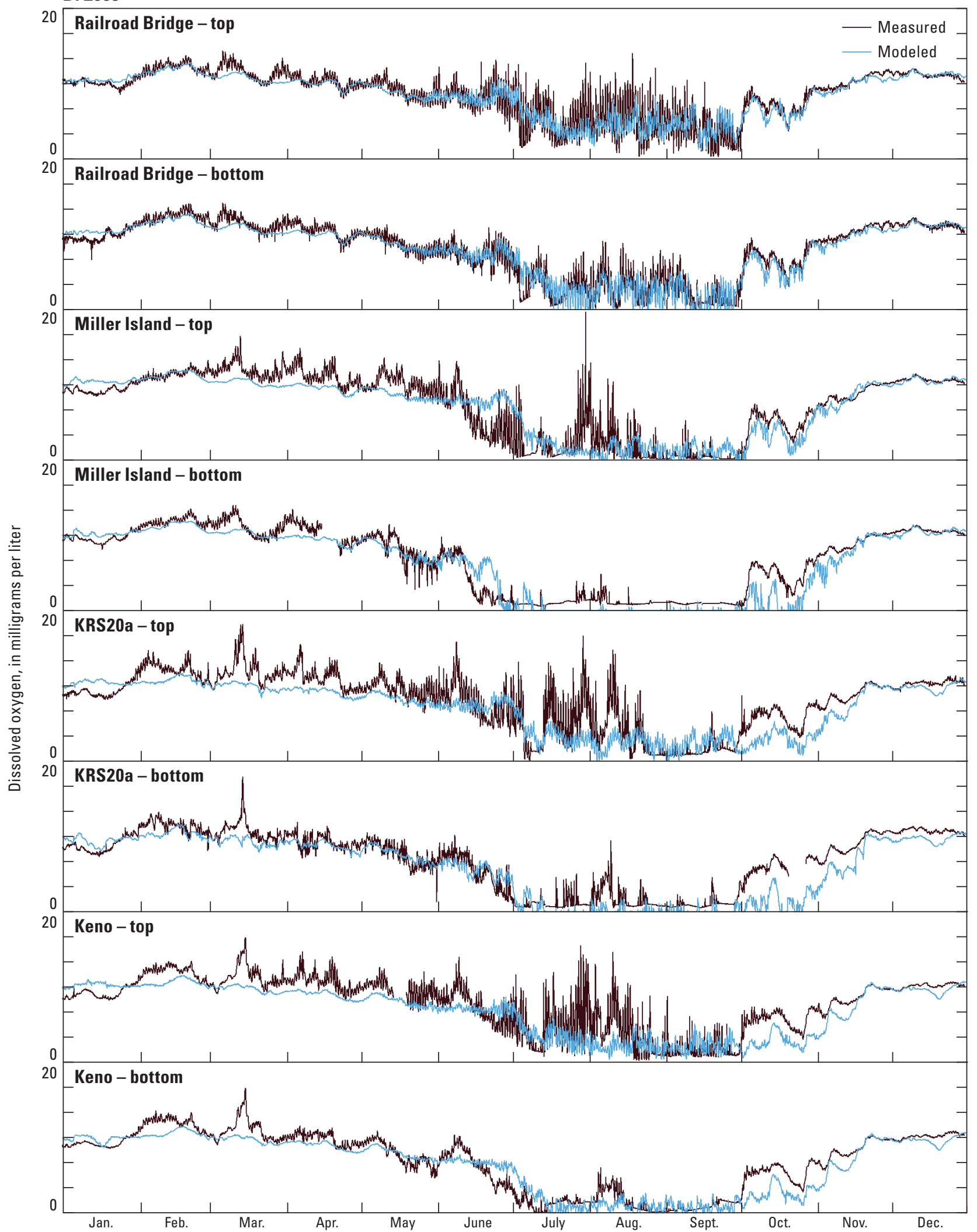

Figure 11.-Continued 

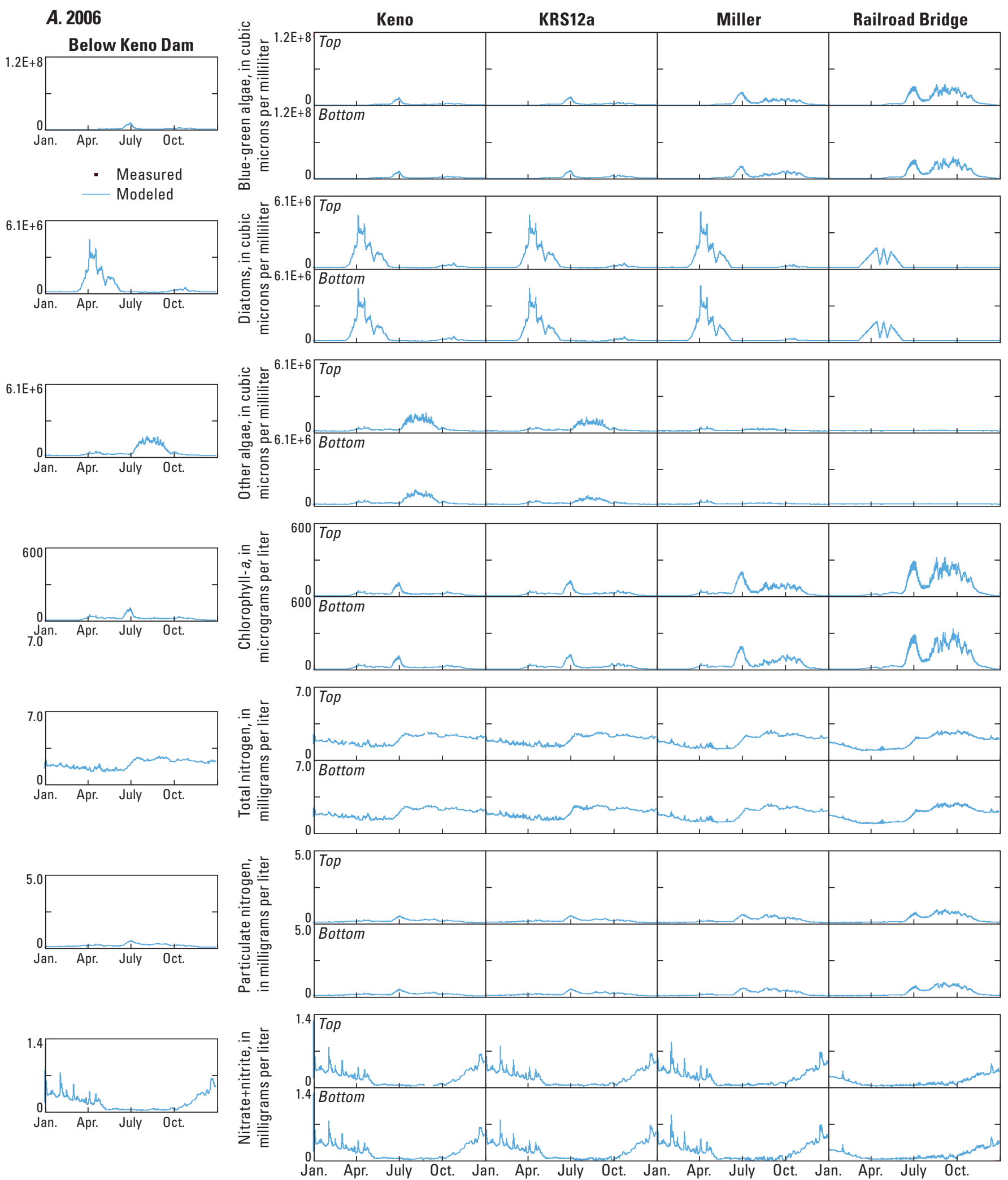

Figure 12. Measured and modeled algae, nutrients, organic matter, and bottom sediment during calendar years $(A) 2006$, $(B) \mathbf{2 0 0 7},(C)$ 2008, and $(D) 2009$ for sites in the Link River to Keno Dam reach of the Klamath River, Oregon. Top results were from 0.5 meters below the river surface; bottom results were from 1 meter above the channel bottom. 

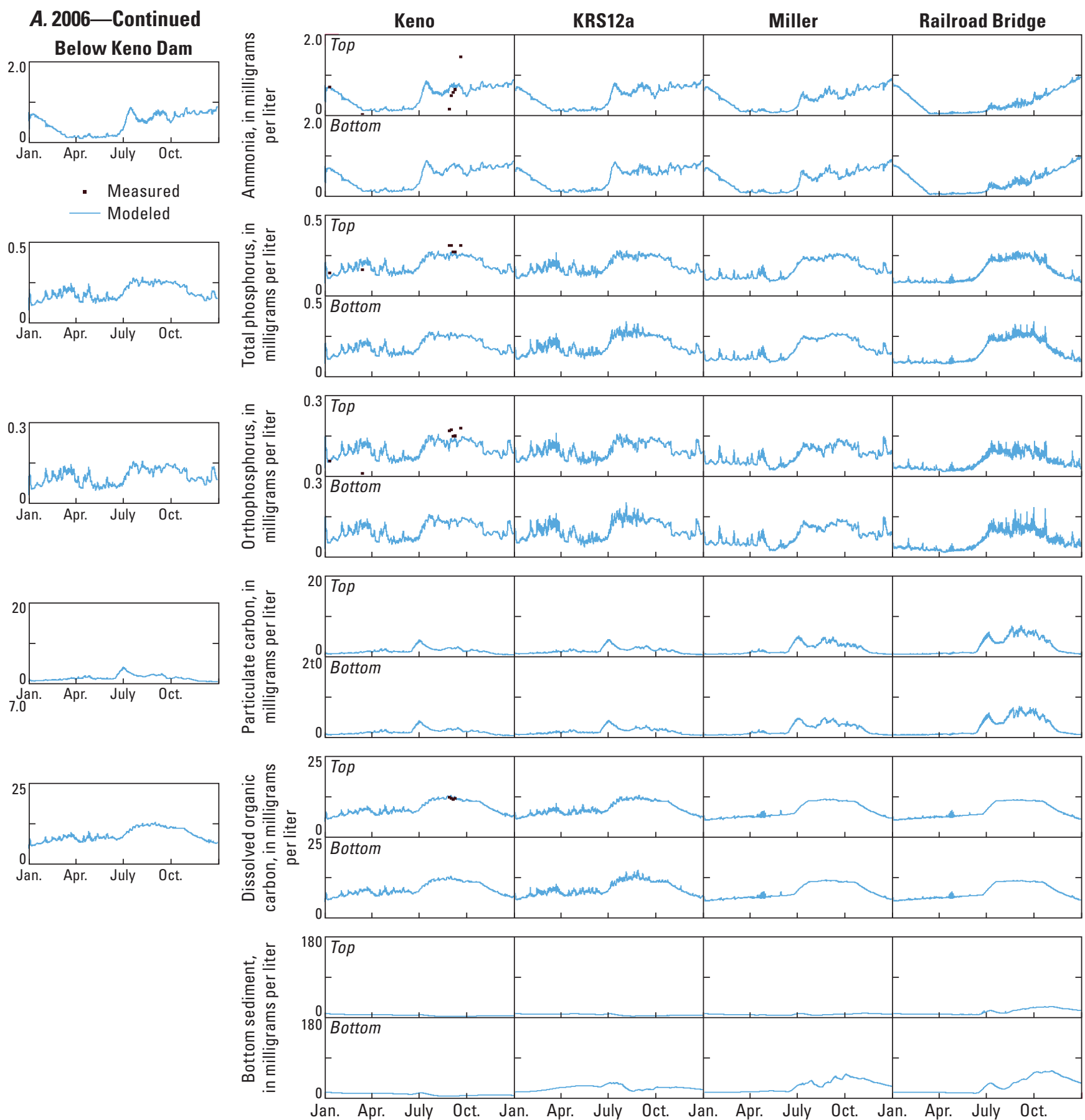

Figure 12.-Continued 
B. 2007
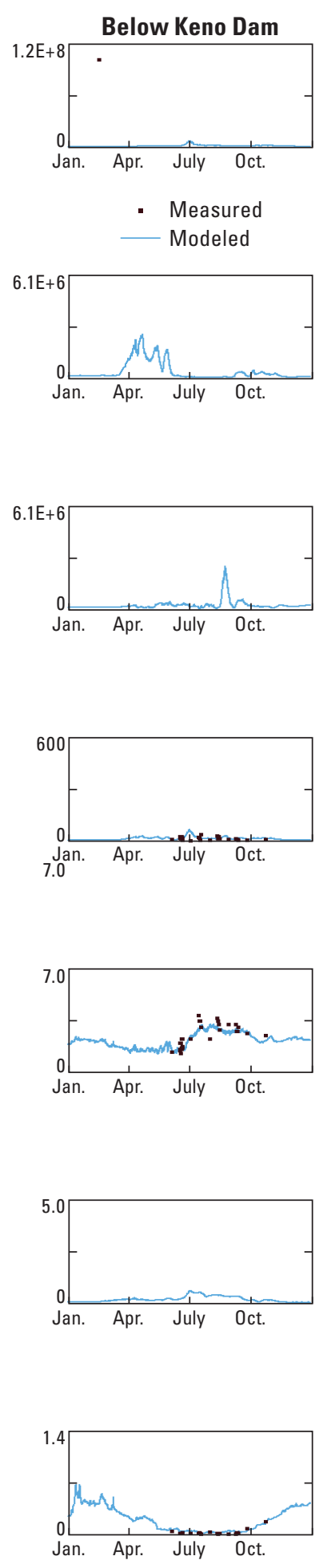

Figure 12.-Continued
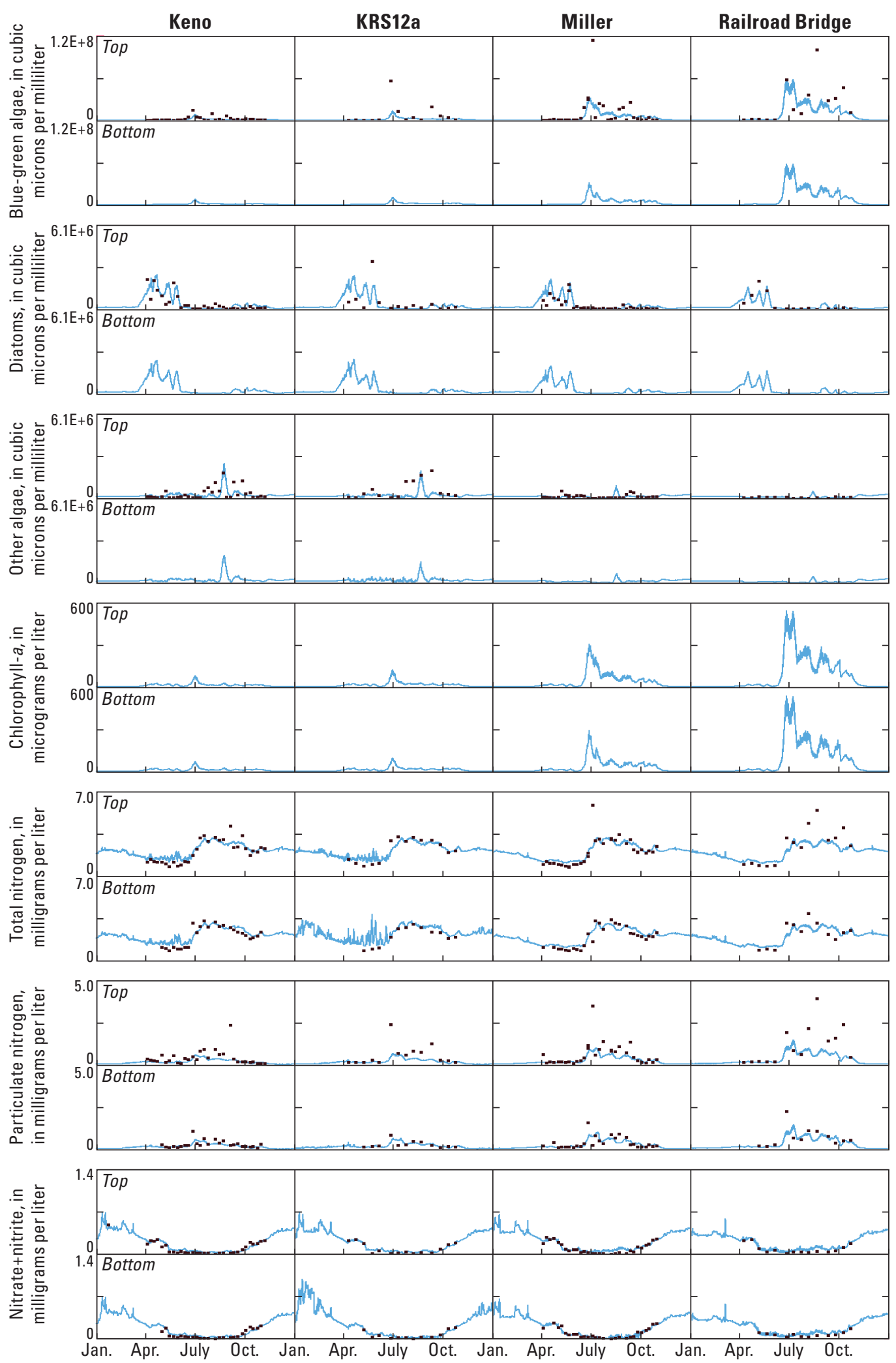

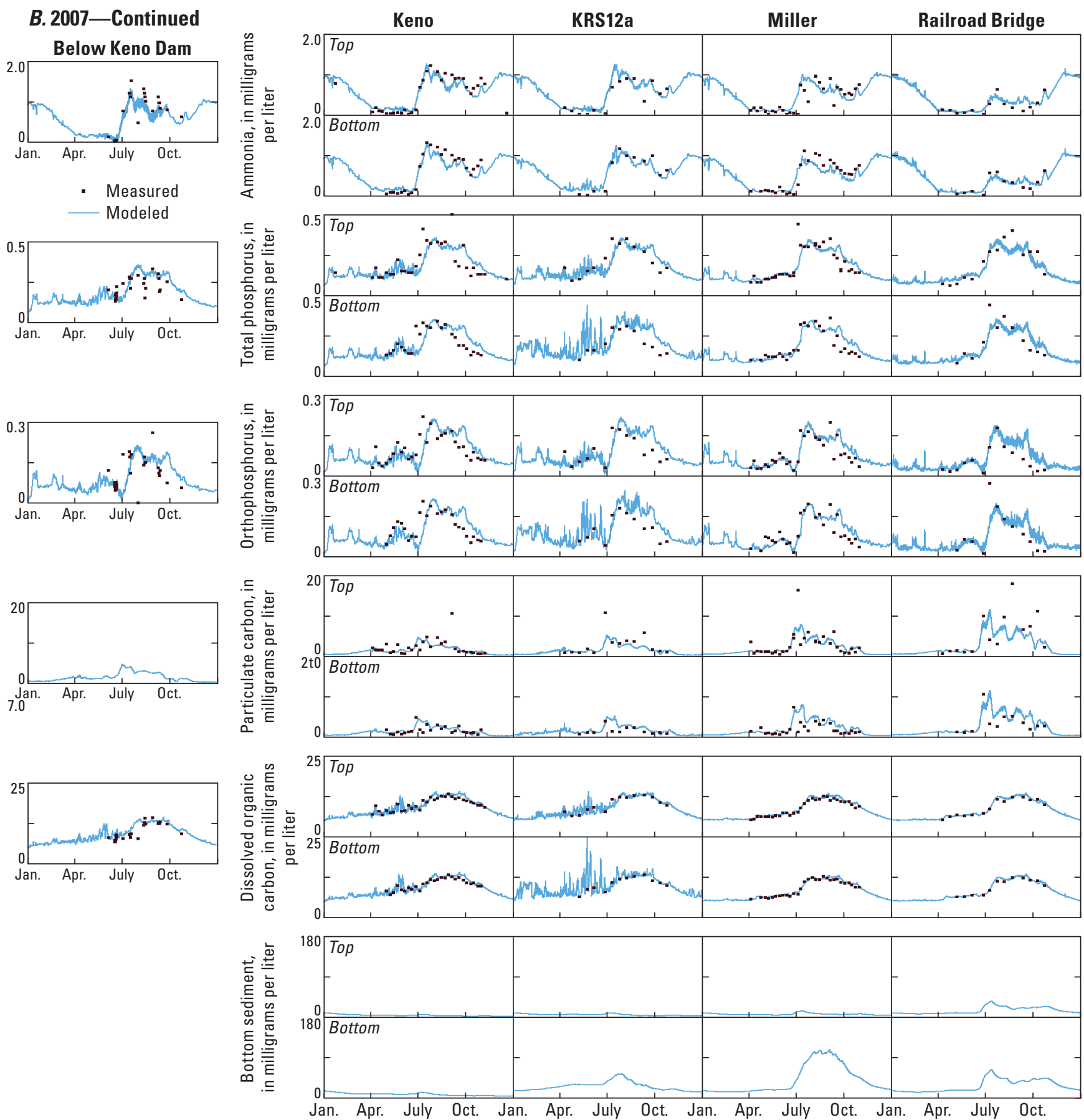

Figure 12.-Continued 

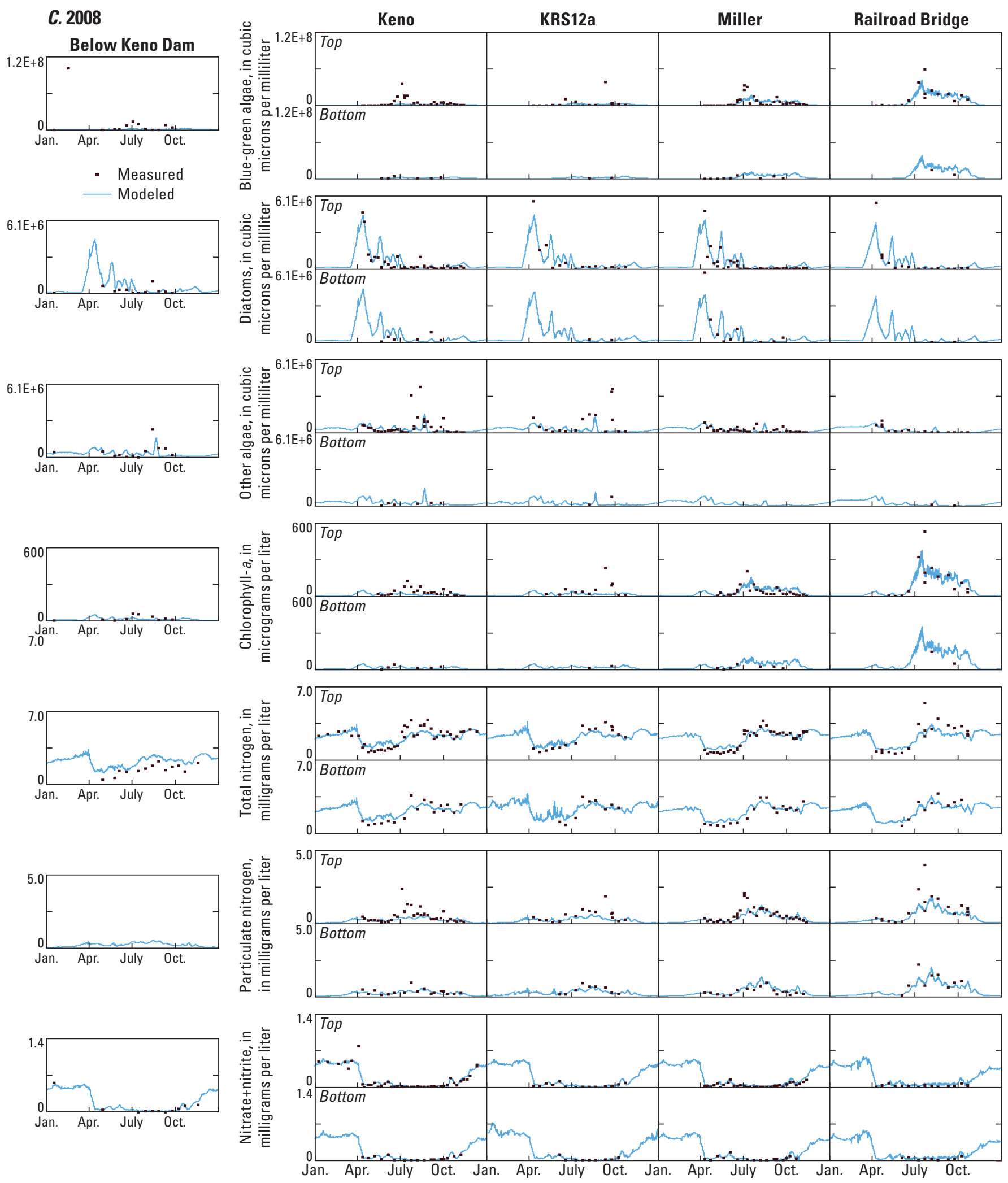

Figure 12.-Continued 

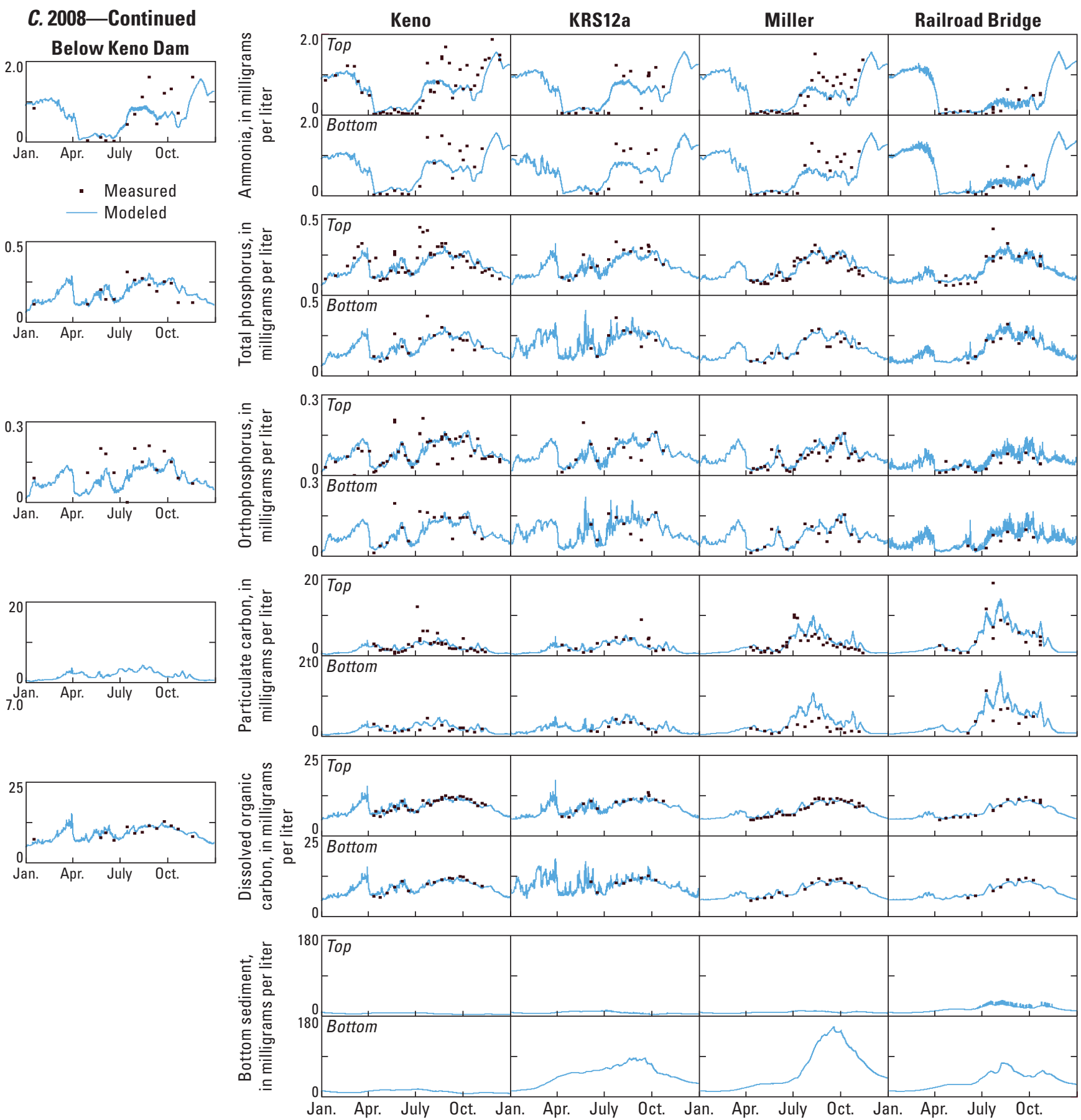

Figure 12.-Continued 

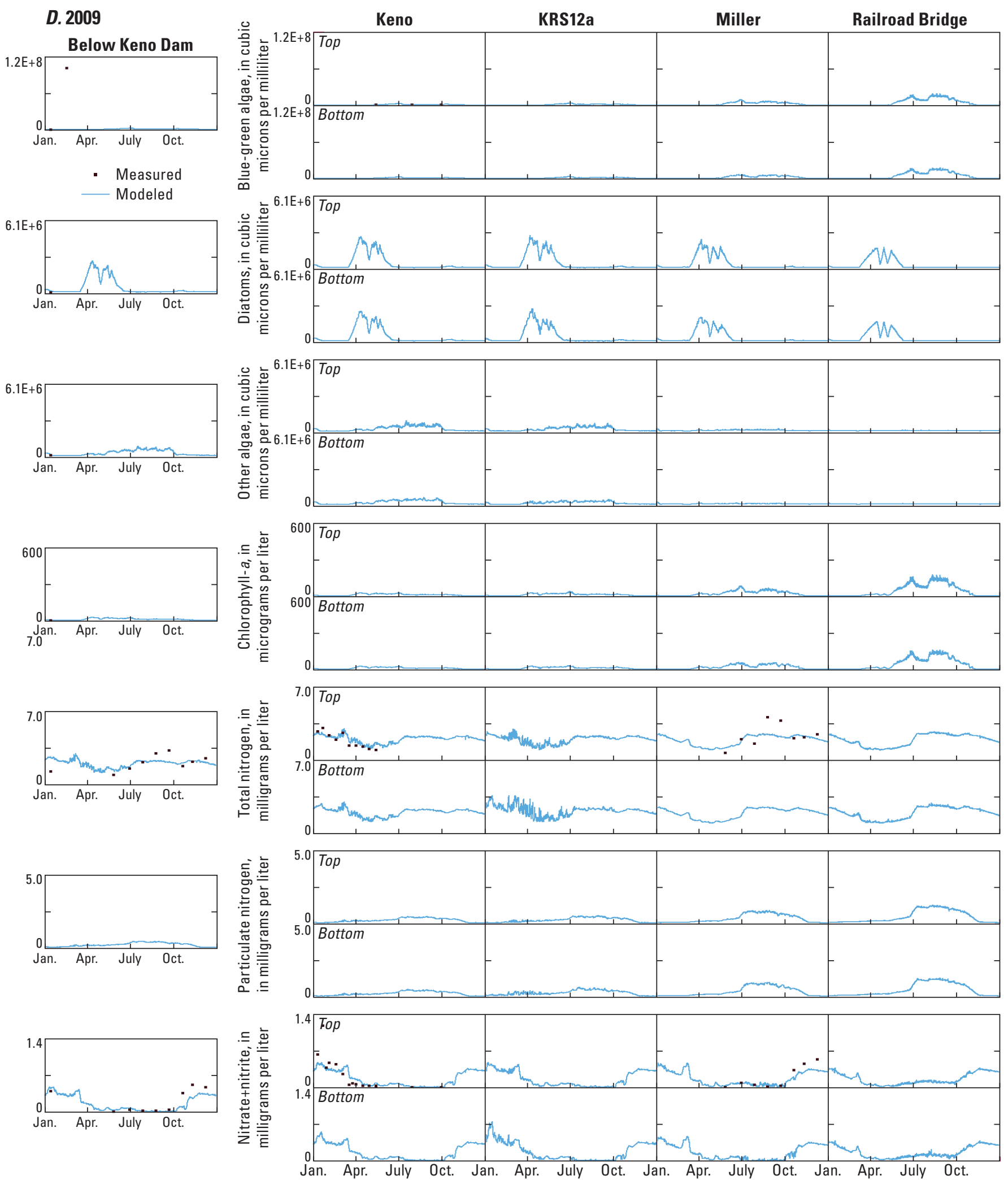

Figure 12.-Continued 

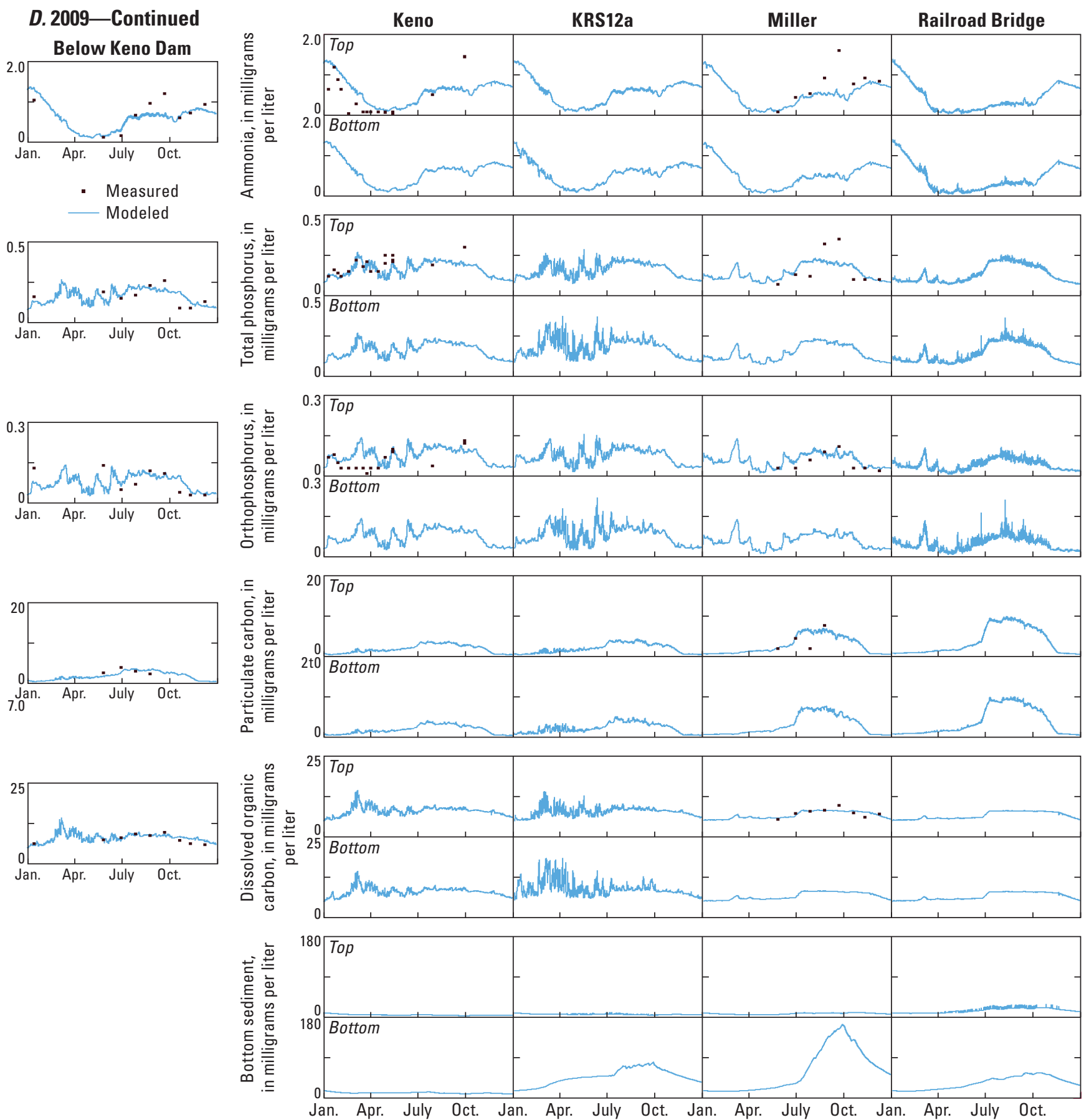

Figure 12.-Continued 


\section{Acknowledgments}

Funding for this study was provided by the Bureau of Reclamation. Dean Snyder (U.S. Geological Survey) conducted the alkalinity analyses. Mariah Tilman, Garrett Steensland, Gunter Schanzenbacher, April Tower, and Tracy McGovern (Bureau of Reclamation) assisted with macrophyte field work. Discussions with Rick Carlson and Jason Cameron (Bureau of Reclamation), Steven Gherini (Tetra Tech) and Chris Berger and Scott Wells (Portland State University) were helpful. Thanks to Mark Sytsma, Vanessa Morgan, Rich Miller, and Robyn Draheim (Portland State University Center for Lakes and Reservoirs) for advice on macrophyte sampling and assistance with macrophyte and snail identification.

\section{Supplementary Material}

Macrophyte field sampling results are provided in spreadsheet form at: http://or.water.usgs.gov/proj/keno_reach/ data.html.

\section{References Cited}

Barko, J.W., Adams, M.S., and Clesceri, N.L., 1981, Environmental factors and their consideration in the management of submersed aquatic vegetation: A review: Journal of Aquatic Plant Management, v. 24, p. 1-10.

Barko, J.W. and Smart, R.M., 1981, Comparative influences of light and temperature on the growth and metabolism of selected submersed freshwater macrophytes: Ecological Monographs, v. 51, p. 219-235.

Bates, R.G., 1951, First dissociation constant of phosphoric acid from $0^{\circ} \mathrm{C}$ to $60^{\circ} \mathrm{C}$-Limitations of the electromotive force method for moderately strong acids: Journal of Research of the National Bureau of Standards, v. 47, p. 127-134.

Bates, R.G., and Acree, S.F., 1943, pH values of certain phosphate-chloride mixtures, and the second dissociation constant of phosphoric acid from $0^{\circ}$ to $60^{\circ} \mathrm{C}$ : Journal of Research of the National Bureau of Standards, v. 30, p. 129-155.

Berger, C.J., 2000, Modeling macrophytes of the Columbia Slough: Portland, Oregon, Portland State University, Ph.D. Dissertation, 278 p.
Berger, C.J., and Wells, S.A., 2008, Modeling the effects of macrophytes on hydrodynamics: Journal of Environmental Engineering, v. 134, p. 778-788.

Bonn, B.A., and Fish, William, 1991, Variability in the measurement of humic carboxyl content: Environmental Science and Technology, v. 25, p. 232-240.

Cashatt, D.N., and Bruce, L.J., 2009, Aquatic plant sampling, in Schultz, R.D., ed., Standard gear and techniques for fisheries surveys in Iowa: Des Moines, Iowa, Iowa Department of Natural Resources Completion Report, 186 p.

Chojnacka, K., 2010, Biosorption and bioaccumulationThe prospects for practical applications: Environment International, v. 36, p. 299-307.

Cole, T.M., and Wells, S.A., 2008, CE-QUAL-W2-A twodimensional, laterally averaged, hydrodynamic and waterquality model, version 3.6: U.S. Army Corps of Engineers, Instruction Report EL-08-1 [variously paged].

Dean, J.A., 1985, Lange's handbook of chemistry (13th ed.): New York, McGraw-Hill, p. 5-16.

Deas, M.L., and Vaughn, J., 2011, Keno Reservoir particulate study 2008-Technical memorandum prepared for the Bureau of Reclamation, Klamath Basin Area Office, April 2011: Davis, California, Watercourse Engineering, Inc., $38 \mathrm{p}$.

Drever, J.I., 1997, The geochemistry of natural watersSurface and groundwater environments (3d ed.): New Jersey, Prentice-Hall, 436 p.

Eilers, J.M., 2005, Aquatic vegetation in selected sites of the Lost River, OR and CA: MaxDepth Aquatics, Inc., prepared for Tetra Tech, Inc., January 2005, 18 p.

Emerson, K.R., Russo, C., Lund, R.E., and Thurston, R.V., 1975, Aqueous ammonia equilibrium calculations-Effect of $\mathrm{pH}$ and temperature: Journal of the Fisheries Research Board of Canada, v. 32, p. 2379-2383.

Gherini, S.A., Mok, L., Hudson, R.J.M., Davis, G.F., Chen, C.W., and Goldstein, R.A., 1985, The ILWAS modelFormulation and application: Water, Air, and Soil Pollution, v. 26, p. 425-459.

Hauxwell, J., Knight, S., Wagner, K., Mikulyuk, A., Nault, M., Porzky, M., and Chase, S., 2010, Recommended baseline monitoring of aquatic plants in Wisconsin-Sampling design, field and laboratory procedures, data entry and analysis, and applications: Wisconsin Department of Natural Resources Bureau of Science Services PUB-SS 2010, 47 p. 
Hem, J.D., 1985, Study and interpretation of the chemical characteristics of natural water (3d ed.): U.S. Geological Survey Water-Supply Paper 2254, p. 105-111. (Also available at http://pubs.usgs.gov/wsp/wsp2254/.)

Hough, R.A., Fornwall, M.D., Negele, B.J., Thompson, R.L., and Putt, D.A., 1989, Plant community dynamics in a chain of lakes-Principal factors in the decline of rooted macrophytes with eutrophication: Hydrobiologia, v. 173, p. 199-217.

Kenow, K.P., Lyon, J.E., Hines, R.K., and Elfessi, A., 2007, Estimating biomass of submersed vegetation using a simple rake sampling technique: Hydrobiologia, v. 575, p. $447-454$.

Körner, S., and Nicklisch, A., 2002, Allelopathic growth inhibition of selected phytoplankton species by submerged macrophytes: Journal of Phycology, v. 38, p. 862-871.

Nichols, S.A., and Shaw, B.H., 1986, Ecological life histories of the three aquatic nuisance plants Myriophyllum spicatum, Potamogeton crispus and Elodea canadensis: Hydrobiologica, v. 131, p. 3-21.

Oregon Department of Environmental Quality, 2007, Oregon's 2004/2006 integrated report: Oregon Department of Environmental Quality Web page, accessed November 16, 2007, at http://www.deq.state.or.us/wq/assessment/rpt0406. htm.

Oregon Department of Environmental Quality, 2010, Upper Klamath and Lost River subbasins; total maximum daily load (TMDL) and water quality management plan (WQMP), accessed December 2010, at http://www.deq. state.or.us/WQ/TMDLs/klamath.htm

Owens, C.S., Smart, R.M., Williams, P.E., and Spickard, M.R., 2010, Comparison of three biomass sampling techniques on submersed aquatic plants in a northern tier lake: U.S. Army Corps of Engineers Report ERDC/TN APCRP-EA-24, July 2010, 9 p.

Pankow, J.F., 1991, Aquatic chemistry concepts: Chelsea, Michigan, Lewis Publishers, 673 p.

Perdue, E.M., Reuter, J.H., and Parrish, R.S., 1984, A statistical model of proton binding by humus: Geochimica et Cosmochimica Acta, v. 48, p. 1257-1263.

Perdue, E.M., and Ritchie, J.D., 2003, Dissolved organic matter in freshwaters: Treatise on Geochemistry, v. 5, p. 273-318.
Poulson, S.R., and Sullivan, A.B., 2010, Assessment of diel chemical and isotopic techniques to investigate biogeochemical cycles in the upper Klamath River, Oregon, USA: Chemical Geology, v. 269, p. 3-11.

Press, W.H., Flannery, B.P., Teukolsky, S.A., and Vetterling, W.T., 1989, Numerical recipes-The art of scientific computing (FORTRAN version): Cambridge, Cambridge University Press, $702 \mathrm{p}$.

Rounds, S.A., 2006, Alkalinity and acid neutralizing capacity (version 4), in National field manual for the collection of water-quality data, Wilde, F.D., and Radtke, D.B., eds.: U.S. Geological Survey Techniques of Water-Resources Investigations, book 9, chap. A6, section 6.6, 53 p. (Also available at http://water.usgs.gov/owq/FieldManual/ Chapter6/section6.6/.)

Rounds, S.A., and Sullivan, A.B., 2009, Review of Klamath River total maximum daily load models from Link River Dam to Keno Dam, Oregon: U.S. Geological Survey Administrative Report, 37 p. (Also available at http:// or.water.usgs.gov/proj/keno_reach/download/klamath river_model review final.pdf.)

Rounds, S.A., and Sullivan, A.B., 2010, Review of revised Klamath River total maximum daily load models from Link River Dam to Keno Dam, Oregon: U.S. Geological Survey Administrative Report, 32 p. (Also available at http:// or.water.usgs.gov/proj/keno reach/download/klamath model_rereview_final.pdf.)

Stumm, Werner, and Morgan, J.J., 1996, Aquatic chemistryChemical equilibria and rates in natural waters (3d ed.): New York, John Wiley and Sons, 1,022 p.

Sullivan, A.B., Deas, M.L., Asbill, J., Kirshtein, J.D., Butler, K., and Vaughn, J., 2009, Klamath River water quality data from Link River Dam to Keno Dam, Oregon, 2008: U.S. Geological Survey Open-File Report 2009-1105, 25 p. (Also available at http://pubs.usgs.gov/of/2009/1105/.)

Sullivan, A.B., Deas, M.L., Asbill, J., Kirshtein, J.D., Butler, K., Stewart, M.A., Wellman, R.E., and Vaughn, J., 2008, Klamath River water quality and acoustic Doppler current profiler data from Link River Dam to Keno Dam, 2007: U.S. Geological Survey Open-File Report 2008-1185, 24 p. (Also available at http://pubs.usgs.gov/of/2008/1185/.)

Sullivan, A.B., Snyder, D.M., and Rounds, S.A., 2010, Controls on biochemical oxygen demand in the upper Klamath River, Oregon: Chemical Geology, v. 269, p. 12-21, doi: 10.1016/j.chemgeo.2009.08.007. 
Sullivan, A.B., Rounds, S.A., Deas, M.L., Asbill, J.R., Wellman, R.E., Stewart, M.A., Johnston, M.W., and Sogutlugil, I.E., 2011, Modeling hydrodynamics, water temperature, and water quality in the Klamath River upstream of Keno Dam, Oregon, 2006-09: U.S. Geological Survey Scientific Investigations Report 2011-5105, 70 p. (Also available at http://pubs.usgs.gov/sir/2011/5105.)

Sullivan, A.B., Rounds, S.A., Deas, M.L., and Sogutlugil, I.E., 2012, Dissolved oxygen analysis, TMDL model comparison, and particulate matter shunting — Preliminary results from three model scenarios for the Klamath River upstream of Keno Dam, Oregon: U.S. Geological Survey Open-File Report 2012-1101, 30 p. (Also available at http:// pubs.usgs.gov/of/2012/1101.)
Tetra Tech, Inc., 2009, Klamath River model for TMDL development, Prepared for U.S. Environmental Agency Region 9 and 10, Oregon Department of Environmental Quality, and North Coast Regional Water Quality Control Board, December 2009: 196 p., accessed May 20, 2011, at http://www.deq.state.or.us/wq/tmdls/docs/klamathbasin/ uklost/KlamathLostAppendixC.pdf.

Tipping, E., 1994, WHAM—A chemical equilibrium model and computer code for waters, sediments, and soils incorporating a discrete site/electrostatic model of ionbinding by humic substances: Computers and Geosciences, v. 20, p. 973-1023. 


\section{Appendix A. CE-QUAL-W2 Macrophyte Code Changes}

The most important macrophyte code changes related to initial conditions are included here. Other minor code changes also were made, including an expansion of macrophyte model flux outputs. For the definitive list of changes, users should compare new and old source code files.

Normal macrophyte initialization is invoked by setting MACWBCI to a value $\geq 0$. With the new code changes, however, if MACWBCI is set to a value $\leq-1.0$, a longitudinal set of initial concentrations is read from the longitudinal profile input file for every cell in the grid. The cell concentrations are read in units of grams per cubic meter, the same units used for MACWBCI. The model reads initial concentrations for each macrophyte group separately and in order, with one line per segment, and the initial concentrations for each layer read from KT to KB (left to right) as 8-character floating point inputs. This is the same input format as other longitudinal inputs; the macrophyte initial concentrations are placed at the end of that input file.

New variables include LONG_MACROPHYTE() and MACCI(). LONG_MACROPHYTE() is a logical, "true" when the user asks to read initial macrophyte concentrations from a longitudinal profile file. MACCI() is a real array holding the longitudinal initial concentrations. The longitudinal concentrations are read and initial macrophyte concentrations and masses are set in the init-cond.f90 source-code file:

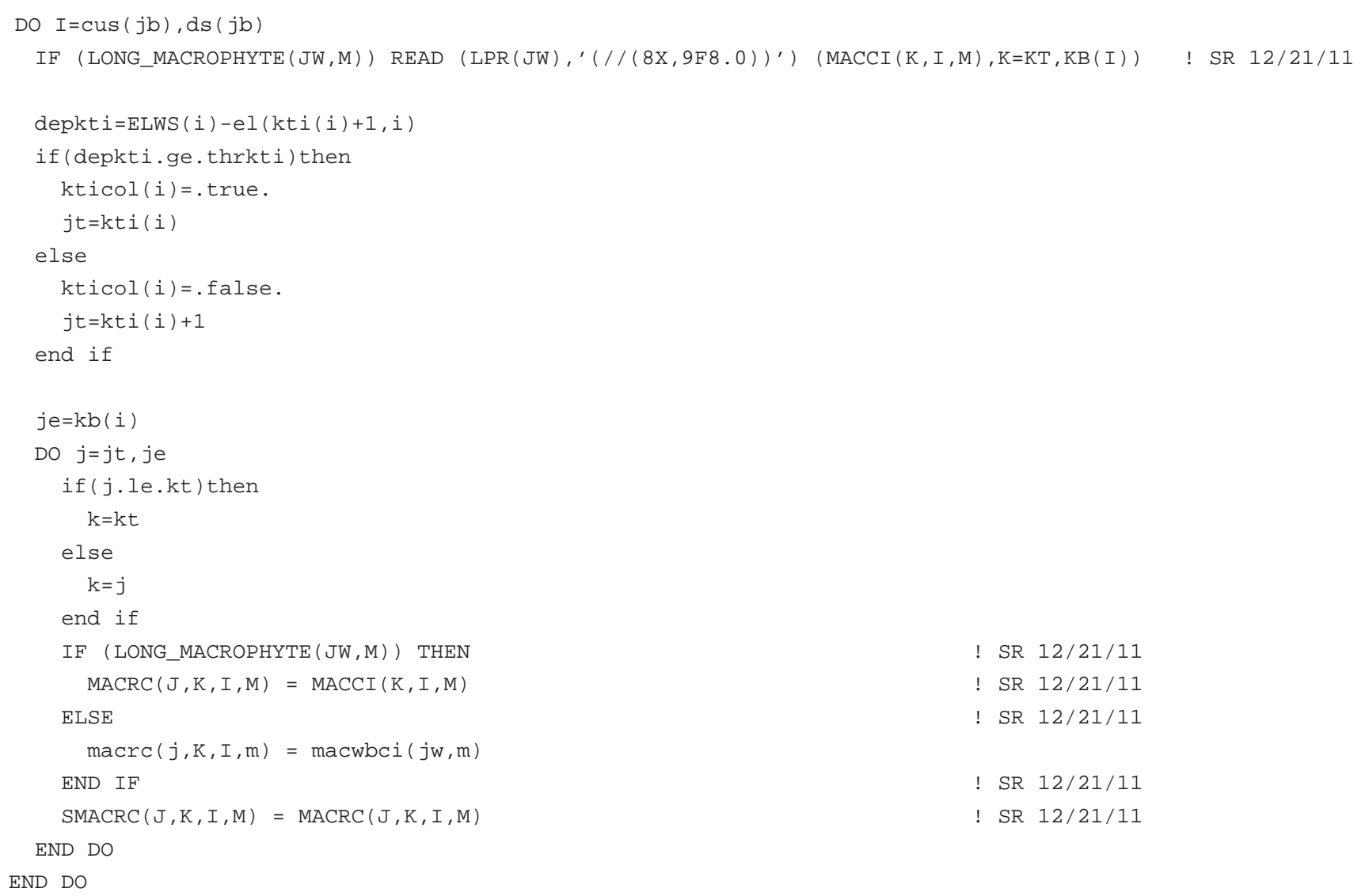

Macrophyte initializations are also dealt with in the layeraddsub.f90 and w2_36_gen.f90 source files. 


\section{Appendix B. CE-OUAL-W2 pH and Alkalinity Code Changes}

The most important code changes made to the CE-QUAL-W2 pH and alkalinity routines are included in this section. For a definitive list of all changes, those who are interested should compare the new and old source files electronically.

The enhanced $\mathrm{pH}$ buffering routines and the nonconservative alkalinity algorithms can be turned on or off by the user through two new global input parameters in the control file on the MISCELL card; that modified card is shown below:

MISCELL NDAY PHBUFC NCALKC

The PHBUFC variable (ON/OFF) controls the use of the enhanced $\mathrm{pH}$ buffering routines; the NCALKC variable (ON/OFF) controls the use of the nonconservative alkalinity algorithms.

If the enhanced $\mathrm{pH}$ buffering routines are turned on, then the model will read a new input file named "ph_buffering.npt" that takes the following form:

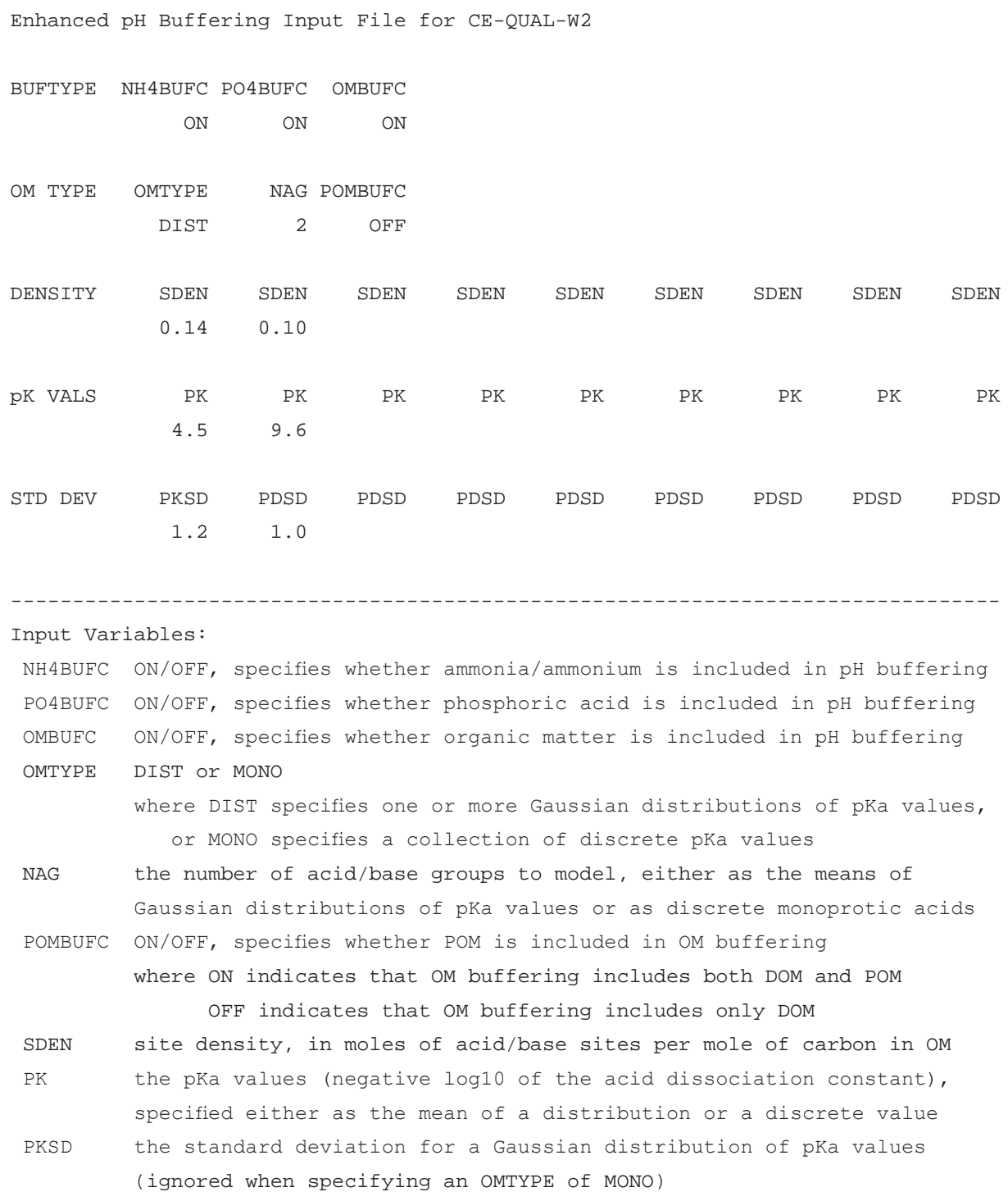


When the model is run with the enhanced $\mathrm{pH}$ buffering capability turned on, the code will generate a new output file named "ph_buffering.opt" based on the new inputs from the ph_buffering.npt file. The object is to echo some of the inputs and provide the user with information on the distribution of site densities and $\mathrm{pK}_{\mathrm{a}}$ values for the organic matter acids. The following is the output that corresponds to the input file shown above:

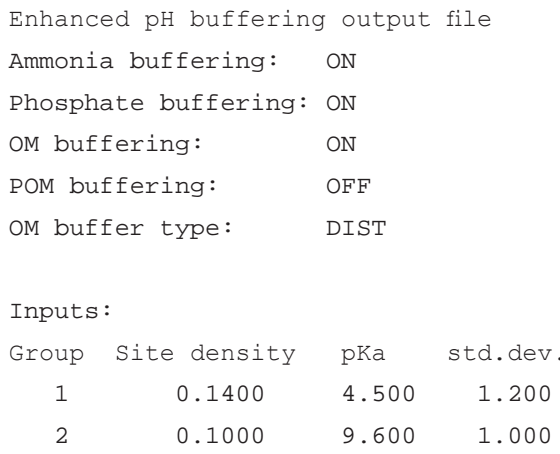


The "ph_buffering.npt" input file is read by using new code in the input.f90 source file, including the following:

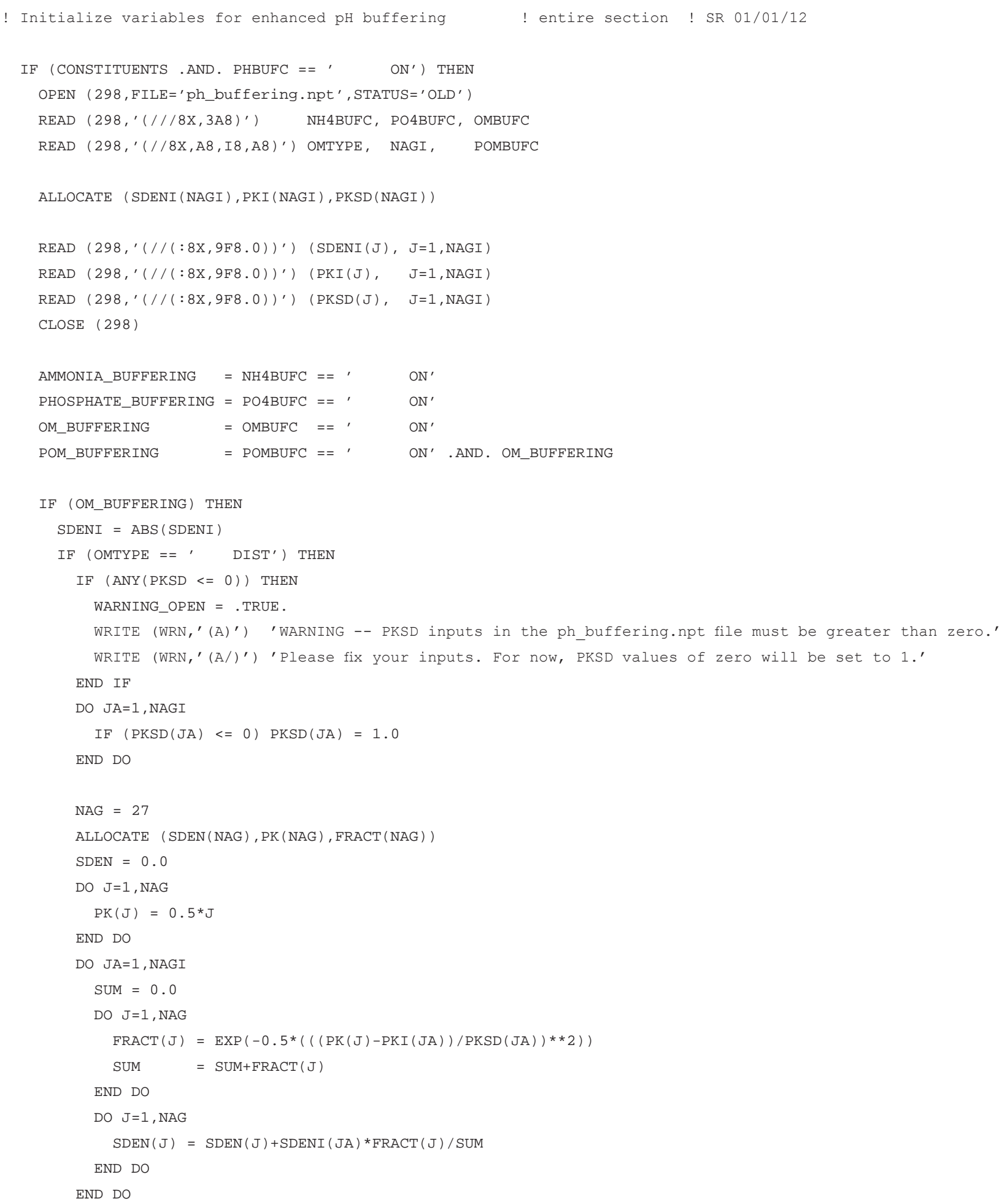




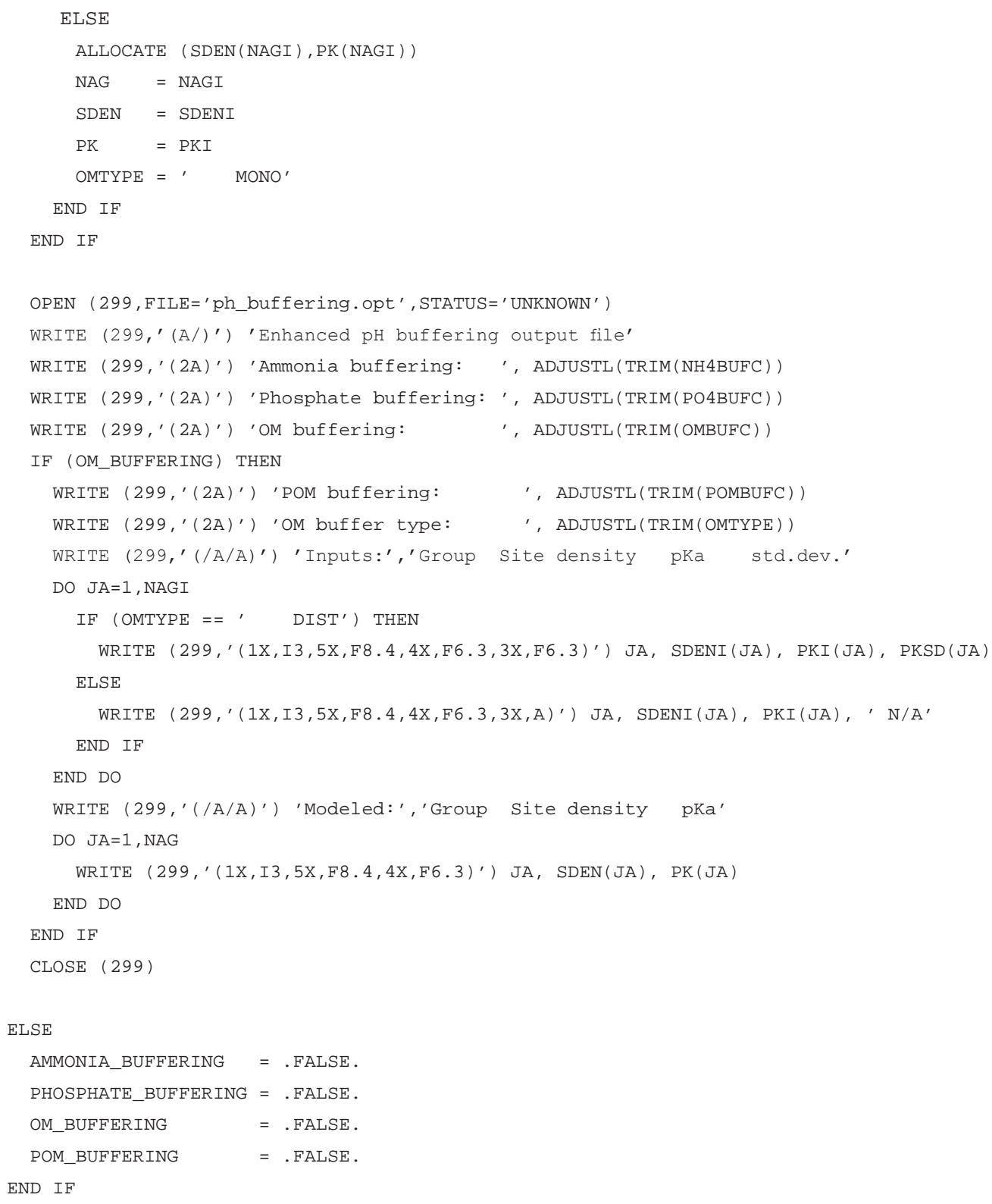




\section{Macrophyte and pH Buffering Updates to the Klamath River Water-Quality Model Upstream of Keno Dam, Oregon}

In the water-quality.f90 source file, the PH_CO2 subroutine was modified to include the optional buffering by ammonia, phosphoric acid, and organic matter. The modified code is:

ENTRY PH_CO2

! Enhancements added for buffering by ammonia, phosphate, and OM ! SR 01/01/12

! $\mathrm{pH}$ and carbonate species

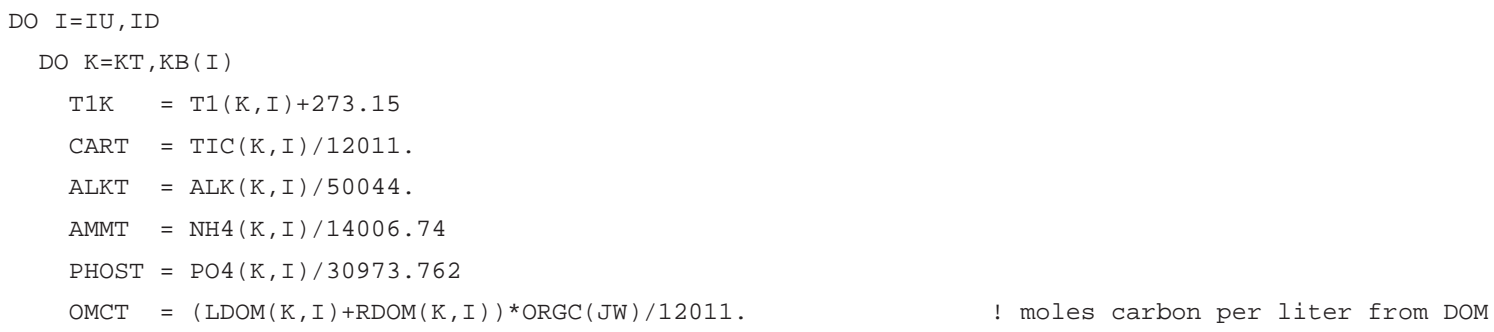

!**** Temperature adjustment

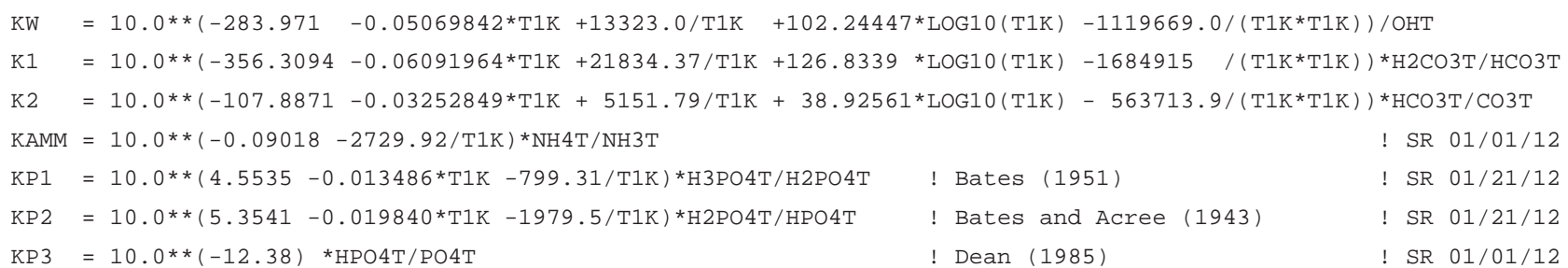




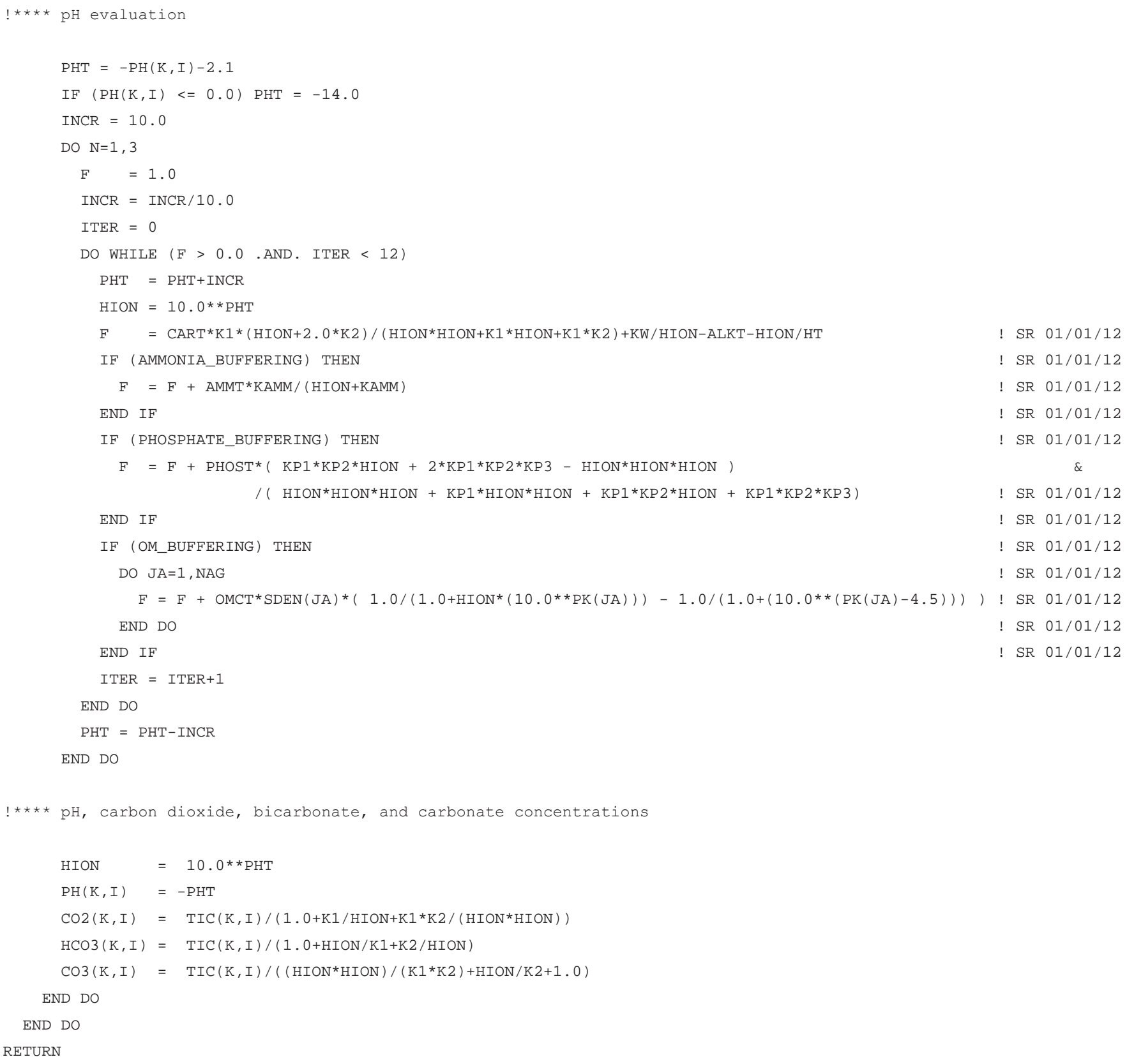


In the water-quality.f90 source file, a new ALKALINITY subroutine was added to realize the nonconservative components of alkalinity. The new code is:

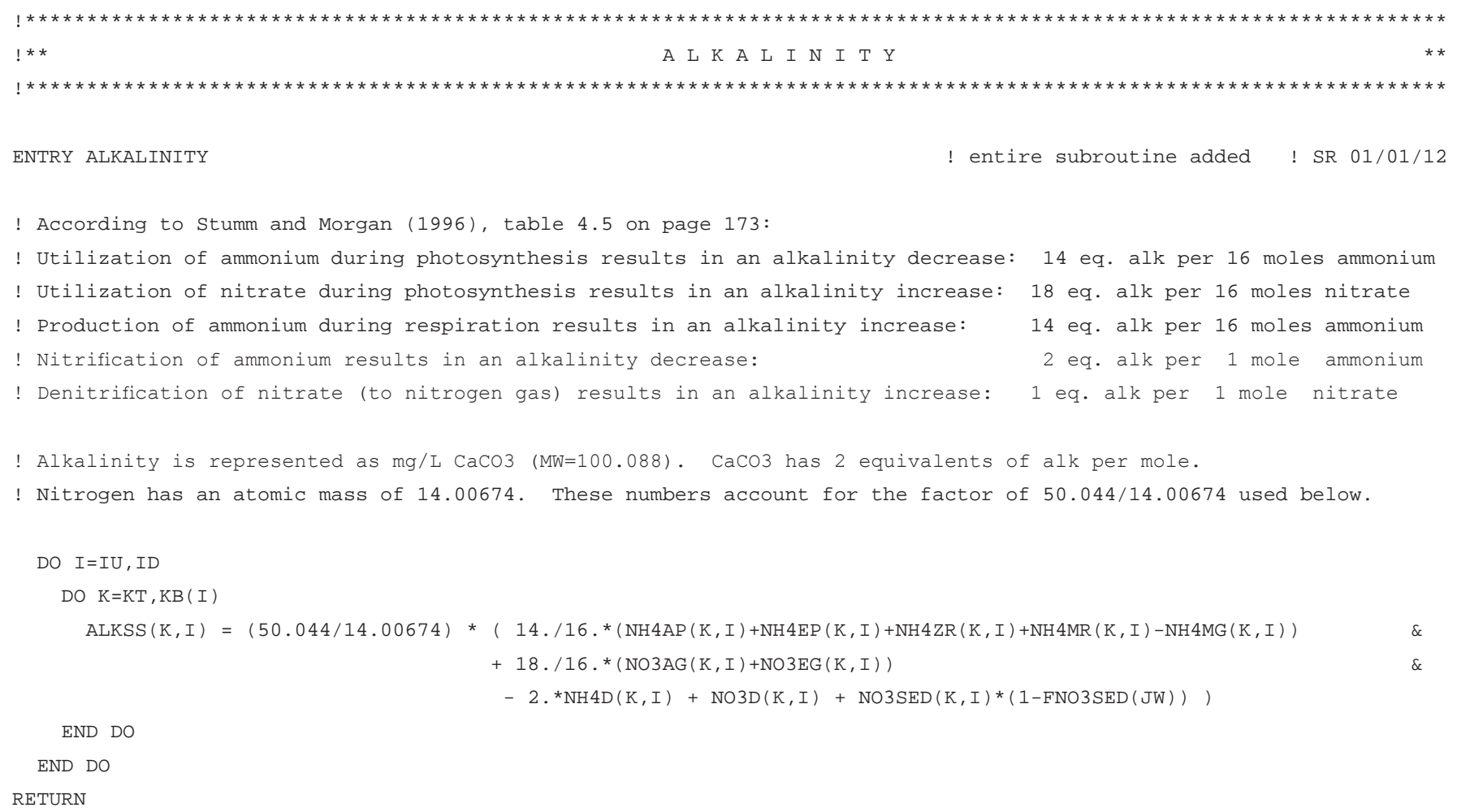


Publishing support provided by the U.S. Geological Survey Publishing Network, Tacoma Publishing Service Center

For additional information contact:

Director, Oregon Water Science Center

U.S. Geological Survey

2130 SW 5th Avenue

Portland, Oregon 97201

http://or.water.usgs.gov 


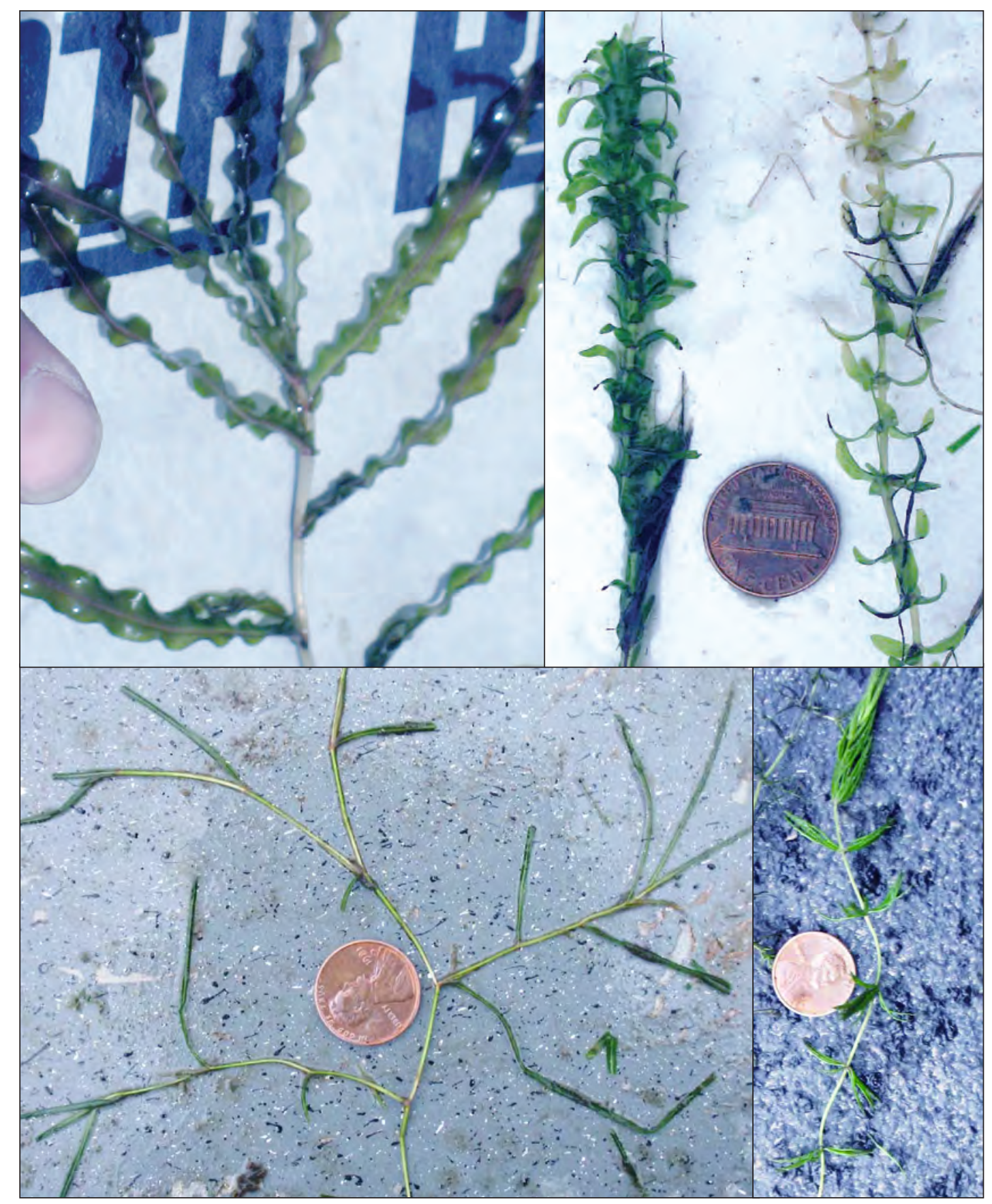

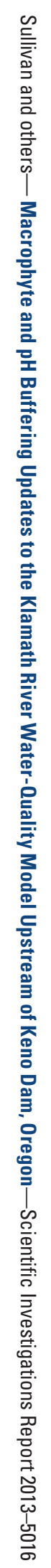

